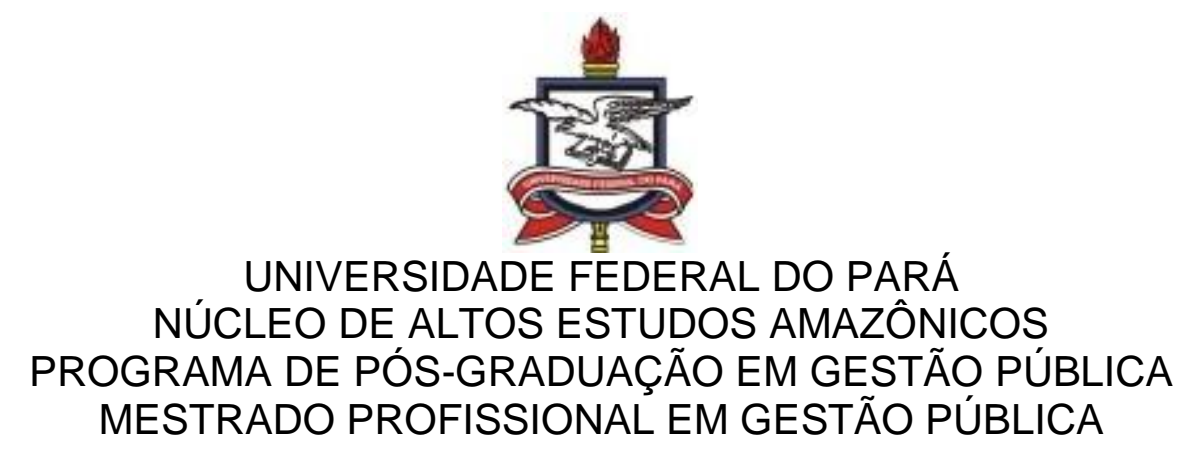

MAURICIO DIAS DA SILVA

A INFORMAÇÃO DE CUSTOS COMO FERRAMENTA DE GESTÃO NA UNIVERSIDADE FEDERAL RURAL DA AMAZÔNIA 
MAURICIO DIAS DA SILVA

\title{
A INFORMAÇÃO DE CUSTOS COMO FERRAMENTA DE GESTÃO NA UNIVERSIDADE FEDERAL RURAL DA AMAZÔNIA
}

\author{
Dissertação apresentada ao Programa de Pós- \\ Graduação em Gestão Pública, do Núcleo de Altos \\ Estudos Amazônicos, da Universidade Federal do Pará \\ como requisito para obtenção do Título de Mestre em \\ Gestão Pública. \\ Orientadora: Prof. ${ }^{\text {a }}$ Dr. ${ }^{\text {a }}$ Marina Yassuko Toma
}


Dados Internacionais de Catalogação na Publicação (CIP)

Sistema de Bibliotecas da Universidade Federal do Pará

Gerada automaticamente pelo módulo Ficat, mediante os dados fornecidos pelo(a) autor(a)

S586i Silva, Maurício Dias da

A informação de custos como ferramenta de gestão na Universidade Federal Rural da

Amazônia / Maurício Dias da Silva. - 2018

122 f. : il. color

Dissertação (Mestrado) - Programa de Pós-graduação em Gestão Pública (PPGGP), Núcleo de Altos Estudos Amazônicos, Universidade Federal do Pará, Belém, 2018.

Orientação: Profa. Dra. Marina Yassuko Toma

1. Instrumentos de Gestão. 2. Sistema de Informação de Custos. 3. Custos no Setor Público. 4. Qualidade do gasto público. I. Toma, Marina Yassuko, orient. II. Título 
MAURICIO DIAS DA SILVA

\title{
A INFORMAČÃO DE CUSTOS COMO FERRAMENTA DE GESTÃO NA UNIVERSIDADE FEDERAL RURAL DA AMAZÔNIA
}

\author{
Dissertação apresentada ao Programa de Pós- \\ Graduação em Gestão Pública do Núcleo de Altos \\ Estudos Amazônicos da Universidade Federal do Pará \\ como requisito para obtenção do Título de Mestre em \\ Gestão Pública.
}

Orientadora: Prof. ${ }^{\text {a }}$ Dr. ${ }^{\text {a }}$ Marina Yassuko Toma

Aprovado em: 05 de Outubro de 2018.

\section{BANCA EXAMINADORA:}

Prof.. D Dr. $^{\text {a Marina Yassuko Toma }}$

Orientadora - PPGGP/NAEA/UFPA

Prof. ${ }^{\text {a }}$ Dr.. Rosana Pereira Fernandes

Examinadora Interna - PPGGP/NAEA/UFPA

Prof. Dr. Anderson Roberto Pires e Silva

Examinador Externo - ICSA/UFPA 


\section{AGRADECIMENTOS}

À Deus, primeiramente, sempre, por me ter dado força e sabedoria para me permitir chegar até essa etapa na busca pelo sonho do título de Mestre.

Ao meu filho Rafael, por ser meu motivo diário de alegria e incentivo a não fraquejar na busca dos objetivos traçados.

À minha mãe Sônia e minha mãe-avó Fátima, pelo amor, compreensão, confiança e apoio. Agradeço especialmente ao meu pai-avô Pedro, por ser nosso grande incentivador nos estudos e maior exemplo de vida. Vocês são meus referenciais e meus "portos seguros".

À minha esposa, Gisele, pela dedicação, parceria e por ter tido paciência nas horas difíceis.

À minha irmã Adriele, meus tios, tias, primos, primas, sobrinhos, sogro, sogra e cunhada pelo apoio e compreensão.

À professora Dra . Marina Yassuko Toma, por sua orientação e pelas valiosas contribuições na construção dessa dissertação.

À Professora Dra . Rosana Pereira Fernandes e ao Professor Dr. Anderson Roberto Pires e Silva, pelas críticas e sugestões, tanto na etapa de qualificação quanto na defesa, que contribuíram de maneira extremamente positiva a este trabalho.

À Professora Drạ. Leila Márcia Sousa de Lima Elias por suas contribuições e conselhos.

Aos professores do Programa de Pós-Graduação em Gestão Pública do NAEAUFPA.

Aos colegas de turma pelos momentos agradáveis de compartilhamento de saberes.

À Universidade Federal Rural da Amazônia pelo incentivo dado aos servidores que buscam melhoria profissional através dos programas de pós-graduação.

Aos meus colegas de trabalho pelo incentivo e apoio ao longo da realização deste trabalho.

A todos os amigos que me apoiaram e motivaram em todas as fases do mestrado, em especial, Ademir, Alexandre, Augusto, Célia, Clíssia, Fernando, Henrique, Jayme, Keila, Louisi, Maria e Marison.

A todos que, de alguma forma, contribuíram para o êxito na minha trajetória no mestrado. 
"Pois qual de vós, querendo edificar uma torre, não se assenta primeiro a fazer as contas dos gastos, para ver se tem com que a acabar? Para que não aconteça que, depois de haver posto os alicerces, e não a podendo acabar, todos os que a virem comecem a escarnecer dele, dizendo: Este homem começou a edificar e não pode acabar." 


\section{RESUMO}

A presente pesquisa buscou demonstrar as diretrizes, os desafios e implicações da adoção da gestão de custos na Universidade Federal da Amazônia (UFRA) através do Sistema de Informação de Custos (SIC). Salienta-se que a Contabilidade de Custos é um instrumento necessário para apuração e mensuração dos resultados das atividades desempenhadas pelo governo, avaliando o alcance dos níveis desejados de eficiência. Busca-se concentrar esforços no estudo da gestão de custos, visando melhor alocação de recursos de maneira que o resultado econômico seja cada vez mais positivo e seja revertido em maiores níveis de excelência dos serviços prestados pela UFRA à sociedade. Considerando os entraves e limitações existentes para a operacionalização do SIC, visto que o índice de utilização desse sistema pelas Instituições Federais é muito baixo, busca-se discutir os benefícios da adoção das informações de custos para fins de tomada de decisão pelos gestores, demonstrando também as ferramentas disponibilizadas que auxiliarão a elaboração dos relatórios de custos. A dissertação demonstrou os relatos da implementação do sistema de informação de custos no Banco Central do Brasil (Bacen) e na Empresa Brasileira de Comunicação (EBC), reconhecidas como duas das melhores práticas de implementação de gestão de custos entre órgãos da esfera federal, e com base nessas experiências e nos dados orçamentários e patrimoniais da UFRA foram propostos modelos e estratégias que se adequem à sua realidade, dentro das normas e legislações vigentes. A pesquisa pode ser classificada como aplicada por sua característica exploratória e também possui caráter multidisciplinar. Utilizou-se análise qualitativa mediante pesquisa bibliográfica e documental. Ao final da pesquisa foram ratificados os benefícios da operacionalização do SIC na UFRA, mediante a apresentação das experiências exitosas do Bacen e da EBC em seus processos de implantação da gestão de custos, posto às semelhanças existentes quanto aos fatores de interferência. Assim, conclui-se que as informações de custos extraídas dos sistemas estruturantes do Governo Federal, utilizando o método de custeio por absorção, contribuirão de maneira relevante aos gestores da UFRA visando o alcance da excelência na gestão e na oferta de serviços à comunidade.

Palavras-chave: Instrumentos de Gestão. Sistema de Informação de Custos. Custos no Setor Público. Qualidade do Gasto Público. 


\begin{abstract}
The present research sought to demonstrate the guidelines, challenges and implications of adopting cost management at the Federal University of Amazonia (UFRA) through the Cost Information System (SIC). It should be noted that Cost Accounting is a necessary instrument for the calculation and measurement of the results of the activities performed by the government, evaluating the achievement of the desired levels of efficiency. It seeks to focus efforts on the study of cost management, aiming at a better allocation of resources so that the economic result is increasingly positive and reverted to higher levels of excellence of the services provided by UFRA to society. Considering the existing obstacles and limitations to the operationalization of the SIC, since the utilization rate of this system by the Federal Institutions is very low, it is sought to discuss the benefits of adopting the cost information for decision making purposes by the managers, the tools available that will assist in the preparation of cost reports. The dissertation showed the reports of the implementation of the cost information system in the Central Bank of Brazil (Bacen) and in the Brazilian Communication Company (EBC), recognized as two of the best practices for implementing cost management among federal agencies, and based on these experiences and on the budgetary and patrimonial data of UFRA, models and strategies have been proposed that are adequate to their reality, within the current norms and laws. The research can be classified as applied for its exploratory characteristic and also has a multidisciplinary character. Qualitative analysis was used through bibliographical and documentary research. At the end of the research, the benefits of the operation of SIC in UFRA were ratified by presenting the successful experiences of Bacen and EBC in their cost management implementation processes, as well as the existing similarities regarding interference factors. Thus, it is concluded that the cost information extracted from the Federal Government structuring systems, using the absorptive costing method, will contribute in a relevant way to the managers of UFRA aiming at achieving excellence in the management and provision of services to the community.
\end{abstract}

Keywords: Management Tools. System of Information of Costs of the Federal Government. Costs in the Government Sector. Quality of Spending. 


\section{LISTA DE QUADROS}

Quadro 1 Implicações da nova administração pública na gestão 23 financeira

Quadro 2 Decisões baseadas nas informações de custos nas 26 empresas privadas

Quadro 3 A obrigatoriedade do uso de informação de custos na 29 legislação brasileira

Quadro 4 Legalidade Orçamentária versus Evidenciação do 31 Patrimônio

Quadro 5 Termos relacionados ao SICSP 34

Quadro 6 Contabilidade Governamental x contabilidade de custos: 36 correspondência terminológica

Quadro 7 Atributos da informação de custos 39

Quadro 8 Sistema de Custos do Governo Federal versus Sistema 46 de Informações de Custos

Quadro 9 Principais Sistemas Estruturantes do Governo Federal $\quad 47$

Quadro 10 Vantagens e Desvantagens do Método de Custeio por 55 Absorção

Quadro 11 Vantagens e Desvantagens do Método de Custeio 56 Variável

Quadro 12 Vantagens e Desvantagens do Método de Custeio ABC 58

Quadro 13 Evolução do orçamento anual da UFRA detalhado 70

Quadro 14 Despesas totais por modalidade de licitação dos anos de 71 2016 e 2017

Quadro 15 Totais das despesas por grupo e elemento de despesa 72 exercícios de 2015 e 2016

Quadro 16 Totais das despesas por grupo e elemento de despesa 74 exercícios de 2016 e 2017

Quadro 17 Análise da evolução das despesas por grupo e elemento 75 de despesa

Quadro 18 Resumo dos principais grupos de recursos identificados 80 pelo Sistema BACEN

Quadro 19 Formulação e gestão das políticas monetária e cambial 82

Quadro 20 Regulação e supervisão do Sistema Financeiro Nacional 83 (SFN)

Quadro 21 Administração do Sistema de Pagamentos Brasileiro 83 (SPB) e do meio circulante

Quadro 22 Direcionadores de Custos do Banco Central 85

Quadro 23 Força de Trabalho x Custo atribuível a Pessoal 105 


\section{LISTA DE FIGURAS}

Figura 1 Contabilidade Financeira, de Custos e Gerencial 26

Figura 2 Círculo Virtuoso da Contabilidade Pública 32

Figura 3 Visão Geral da correspondência dos conceitos entre a 35 contabilidade governamental e de custos

Figura 4 Ajustes patrimoniais para geração de informação de custos 43

Figura 5 Mudança cultural na gestão através do SIC 45

Figura 6 Sistemas Estruturantes do Governo Federal - Visão 47 Sistêmica

Figura 7 Ciclo Orçamentário - SIC 63

$\begin{array}{lll}\text { Figura } 8 & \text { Organograma da UFRA } & 67\end{array}$

$\begin{array}{lll}\text { Figura } 9 & \text { Sistemática de obtenção do custo dos objetos de custos } & 79\end{array}$

Figura 10 Fluxo de agregação de custos adotado pelo BaCen 81

Figura 11 Os quatro níveis dos objetos de custos do BACEN 82

Figura 12 Quatro etapas do Custo Personalizado 90

Figura 13 Codificação do Planejamento Orçamentário e de Custos 92

Figura 14 Codificação do Planejamento Orçamentário 92

Figura 15 Modelo de apuração dos custos indiretos da EBC 97

Figura 16 Extração dos Dados de Custos na EBC 98 


\section{LISTA DE GRÁFICOS}

Gráfico 1 Custos por Diretorias 93

Gráfico 2 Visões da Codificação de Custos 94

Gráfico 3 Mapa de custos por praça ou região de atuação da EBC 95

Gráfico 4 Painel de Custos 99

Gráfico 5 Painel Detalhamento dos Custos 99

Gráfico 6 Painel Custos dos Serviços Prestados - CSP 100

Gráfico 7 Painel Custos Consolidados 101

Gráfico 8 Painel de Custos por Diretorias 101 


\section{LISTA DE SIGLAS E ABREVIATURAS}

$\mathrm{ABC}$

$\mathrm{AH}$

Bacen

BGU

$\mathrm{CF}$

CFC

DW

EBC

ICA

ICIBE

IFES

IN

INMETRO

ISARH

ISPA

LDO

LOA

LRF

MCASP

MEC

MPCUST

MPOG

NBC T

NBCASP

OD

PCASP

PDI

PNE

PPA

PROAES

PROAF

PROEN
Activity Based Costing

Análise Horizontal

Banco Central do Brasil

Balanço Geral da União

Constituição Federal

Conselho Federal de Contabilidade

Data Warehouse

Empresa Brasileira de Comunicação

Instituto de Ciências Agrárias

Instituto Ciberespacial

Instituição Federal de Ensino Superior

Instrução Normativa

Instituto Nacional de Metrologia, Qualidade e Tecnologia

Instituto Sócio Ambiental e Recursos Hídricos

Instituto de Saúde e Produção Animal

Lei de Diretrizes Orçamentárias

Lei Orçamentária Anual

Lei de Responsabilidade Fiscal

Manual de Contabilidade Aplicada ao Setor Público

Ministério da Educação

Macroprocesso do Sistema de Custos do Governo Federal

Ministério do Planejamento, Orçamento e Gestão

Norma Brasileira de Contabilidade Técnica

Normas Brasileiras de Contabilidade Aplicadas ao Setor Público

Ordenadores de despesas

Plano de Contas Aplicado ao Setor Público

Plano de Desenvolvimento Institucional

Plano Nacional da Educação

Plano Plurianual

Pró-Reitoria de Assuntos Estudantis

Pró-Reitoria de Administração e Finanças

Pró-Reitoria de Ensino 


$\begin{array}{ll}\text { PROEX } & \text { Pró-Reitoria de Extensão } \\ \text { PROGEP } & \text { Pró-Reitoria de Gestão de Pessoas } \\ \text { PROPED } & \text { Pró-Reitoria de Pesquisa e Desenvolvimento Tecnológico } \\ \text { PROPLADI } & \text { Pró-Reitoria de Planejamento e Desenvolvimento Institucional } \\ \text { REUNI } & \text { Programa de Apoio a Planos de Reestruturação e Expansão das } \\ & \text { Universidades Federais } \\ \text { RG } & \text { Relatório de Gestão } \\ \text { RKW } & \text { Reichskuratorium fur Wirtshaftlichkeit } \\ \text { SECEX } & \text { Secretarias Executivas } \\ \text { SERPRO } & \text { Serviço de Processamento de Dados do Governo Federal } \\ \text { SIADS } & \text { Sistema Integrado de Administração de Serviços } \\ \text { SIAFI } & \text { Sistema Integrado de Administração Financeira do Governo } \\ & \text { Federal } \\ \text { SIAPE } & \text { Sistema Integrado de Administração de Recursos Humanos } \\ \text { SIASG } & \text { Sistema Integrado de Administração de Serviços Gerais } \\ \text { SIC } & \text { Sistema de Informação de Custos } \\ \text { SICSP } & \text { Sistema de Informação de Custos do Setor Público } \\ \text { SIOP } & \text { Sistema Integrado de Planejamento e Orçamento } \\ \text { SIORG } & \text { Sistema de Organização e Inovação Institucional } \\ \text { SOF } & \text { Secretaria de Orçamento Federal } \\ \text { SPIUNET } & \text { Sistema de Gestão dos Imóveis de Uso Especial da União } \\ \text { SPOAS } & \text { Subsecretarias de Planejamento, Orçamento e Administração } \\ \text { STN } & \text { Secretaria do Tesouro Nacional } \\ \text { TCU } & \text { Tribunal de Contas da União } \\ \text { UFMS } & \text { Fundação Universidade Federal do Mato Grosso do Sul } \\ \text { UFRA } & \text { Universidade Federal Rural da Amazônia } \\ \text { UPC } & \text { Unidades Prestadoras de Contas ao TCU } \\ & \end{array}$




\section{SUMÁRIO}

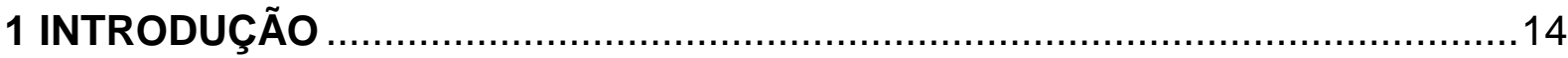

1.1 Problema de Pesquisa ................................................................. 16

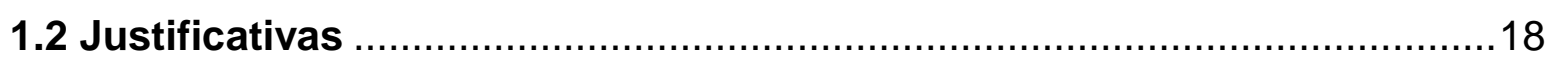

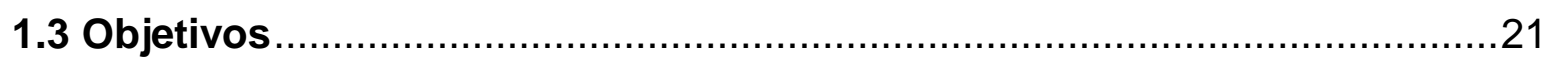

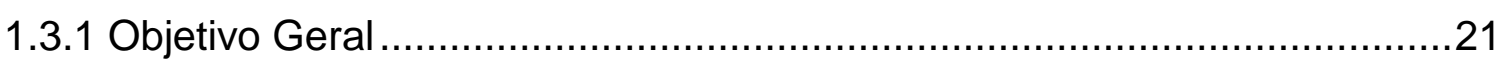

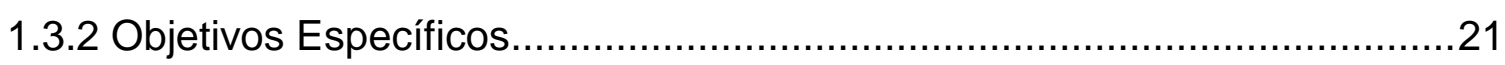

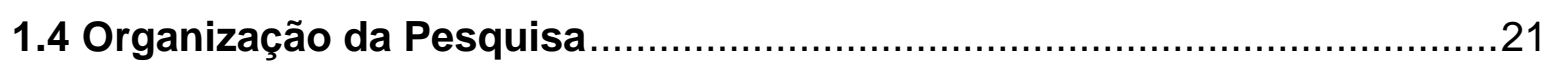

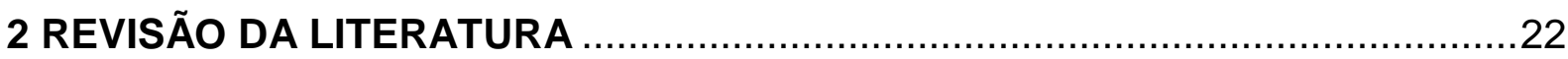

2.1 A Nova Gestão Pública e o Movimento de Reforma do Estado Brasileiro22

2.2 Contabilidade de Custos no Setor Público...........................................25

2.2.1 Sistema de Informação de Custo do Setor Público - NBC T 16.11 ...........33

2.2.2 O regime de Competência para geração de informações de custos .........40

2.3 Sistema de Informações de Custos do Governo Federal - SIC .................44

2.3.1 Funcionamento e objetivos do SIC ..............................................46

2.4 Informações de Custos das Unidades Prestadoras de Contas ao TCU ....50

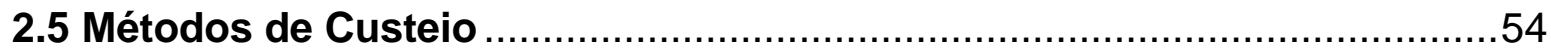

2.6 Objetos de Custo .......................................................................... 61

3 PROCEDIMENTOS METODOLÓGICOS ..................................................64

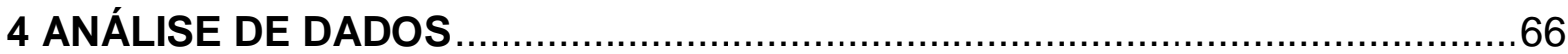

4.1 Caracterização do objeto de estudo..............................................66

4.1.1 Desempenho Orçamentário da UFRA no período de 2015 a 2017 ..........68

4.2 Melhores práticas de utilização do sistema de informação de custos no Brasil

4.2.1 A experiência de implantação de um Sistema de Custos no Banco Central do Brasil - Método ABC

4.2.2 A experiência da implantação da sistematização de custos na Empresa

Brasileira de Comunicação S/A - Método Absorção .89

4.3 Lições extraídas a partir dos relatos e etapas iniciais da estruturação.. 104

4.4 Roteiro sugerido para uma estrutura de gestão de custos na UFRA ......107

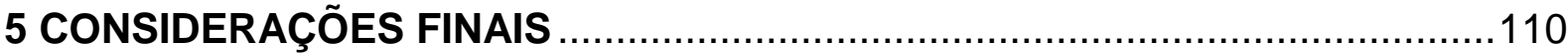

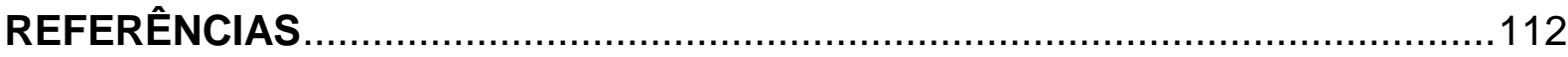

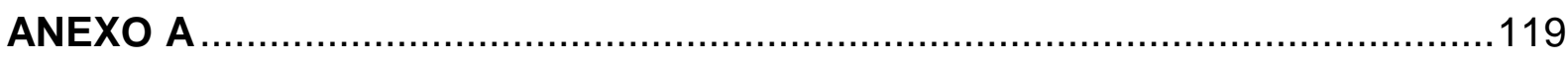

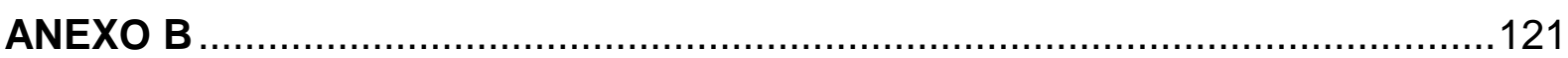




\section{INTRODUÇÃO}

O movimento da Nova Gestão Pública no início dos anos 70 do século passado levou os governos a repensar a Administração Pública. O modelo de organização burocrática apresentara falhas para apresentar uma gestão efetiva em razão dos seus processos considerados simples, ineficazes e irresponsáveis. As organizações burocráticas demonstravam inflexibilidade no processo de tomada de decisão, luta constante pelo poder e autoridade, e consequentemente, tinham baixa capacidade de resposta, falta de iniciativa, excessos de formalismos e altos custos de funcionamento (ARAÚJO, 2013).

Araújo (2013) menciona que esse modelo tradicional ancorado na hierarquia e na autoridade passou então por mudanças proporcionadas pela nova etapa da Administração Pública, que atingiu três áreas relevantes das organizações, que foram as formas de trabalho em equipe, prestação de contas dos trabalhos e a entrega dos serviços públicos, além da participação dos cidadãos. Complementarmente, outras teorias que contribuem para a Nova Gestão Pública, baseadas na produtividade, desempenho e controle, e influenciadas pelo Gerencialismo, foram utilizadas pelos reformadores para introduzir a eficiência na Administração Pública.

Nesse contexto, considerando a importância de se trazer à gestão pública indicadores de eficiência, eficácia e efetividade, busca-se estudar as fases de implantação de um sistema de custos e sua efetiva aplicação nos atos gestionários de um órgão público. Isso requer embasamento teórico e técnico para o convencimento da gestão superior o órgão em investir nessa ferramenta. Para isso é necessário apresentar análises de dados que comprovem a sua viabilidade, possibilidade de retorno econômico, orçamentário e financeiro à instituição, e consequentemente, ampliação e melhoria dos serviços prestados à sociedade.

A Universidade Federal Rural da Amazônia (UFRA) assim como as demais Instituições Federais de Ensino Superior (IFES), têm sofrido restrições orçamentárias nos últimos anos que afetaram de maneira significativa sua forma de gerenciamento de despesas e obtenção de receitas. Mediante um cenário adverso como o apresentado, há que se considerarem alternativas para compensar essa limitação, seja através da obtenção de recursos externos para fomentar a pesquisa, o ensino e a extensão, seja através de um gerenciamento rigoroso dos recursos 
recebidos oriundos do Orçamento da União através da otimização dos gastos e utilização de ferramentas de custos para tomada de decisão.

A segunda alternativa apresentada norteia o presente trabalho, considerando que existem determinações legais para que os órgãos da administração pública adotem sistema de controle de custos, visando estabelecer parâmetros e comparar os indicadores de eficiência dos gastos públicos. Ademais, Martins (2003) aponta duas funções relevantes da Contabilidade de Custos: o auxílio ao Controle e a ajuda às tomadas de decisões. Portanto, a adoção do gerenciamento de custos vai além da obrigatoriedade legal, deve ser visualizada sob o prisma dos benefícios e vantagens que essa ferramenta gerencial proporciona aos gestores públicos.

Em virtude da relevância do assunto em tela e dos esforços que vem sendo dispendidos pelo Governo Federal para entregar uma ferramenta completa, o Sistema de Informação de Custos (SIC), e para que os órgãos subordinados adotem a sistemática de apuração de custos, faz-se necessário apresentar estudos dedicados ao tema de custo do setor público para munir de conhecimento os principais usuários dessas informações, como a alta gestão, os gestores das unidades organizacionais, os stakeholders, a comunidade acadêmica e a sociedade em geral.

A sistemática de apuração de custos no setor público é também um reflexo do processo de renovação da gestão pública, decorrente da adoção do novo modelo gerencialista, que além de trazer o aspecto gerencial ao setor público, busca aumentar o grau de transparência e melhoria da qualidade dos serviços ofertados à população, além de servir como ferramenta de controle social.

Com esse pensamento, apresenta-se no presente estudo os aspectos legais relativos à sistemática de apuração de custos nos órgãos públicos, e os normativos técnicos oriundos do Conselho Federal de Contabilidade (CFC) que dispõe sobre o tema, as metodologias de custos que podem ser utilizadas, cases de sucesso em outros órgãos públicos, de forma que possam nortear a implementação na UFRA, considerando as suas especificidades.

Almeja-se com isso, demonstrar a importância da contabilidade de custos aplicada ao setor público e aplicação dos métodos de custeio para a melhoria da qualidade dos serviços prestados como forma de controle e mensuração dos gastos na UFRA. 


\subsection{Problema de Pesquisa}

O fornecimento de informações sobre o custo das atividades desenvolvidas pelo governo ganhou impulso nos últimos anos mediante a pressão social por melhoria do desempenho e da eficiência. A partir disso, ganha ênfase a tomada de decisões sobre uso dos recursos orçamentários com foco no alcance dessas melhorias. Assim, mais do que saber quanto o governo gasta com a provisão de bens e serviços, é necessário identificar os resultados gerados por esse gasto e se poderiam ser alcançados com menores custos para o contribuinte (REZENDE; CUNHA; BEVILACQUA, 2010).

Quando se trata de eficiência, especificamente voltada aos serviços públicos, é necessário trazer à tona que sua origem advém do disposto no Art. 37 da Constituição Federal (BRASIL, 1988, grifo nosso) que determina no seu caput:

Art. 37. A administração pública direta e indireta de qualquer dos Poderes da União, dos Estados, do Distrito Federal e dos Municípios obedecerá aos princípios de legalidade, impessoalidade, moralidade, publicidade e eficiência [...].

O princípio da eficiência preocupa-se com a melhor utilização possível dos recursos públicos para coibir desperdícios. Além disso, as decisões sobre alocação de recursos e avaliação de resultados necessariamente devem seguir os procedimentos legais definidos na legislação orçamentária e o princípio da eficiência deve ser o seu norteador (MACHADO, 2002).

Machado (2002) menciona que o princípio da eficiência foi introduzido no arcabouço jurídico nacional pela Emenda Constitucional $n^{\circ} 19 / 98$, e que ela juntamente com toda legislação que disciplina o orçamento público integram o modelo de decisão amplo do setor público.

Para que o estudo sobre custos no setor público visando à eficiência atingisse o patamar atual, é necessário lembrar que, previamente, no âmbito empresarial, a Contabilidade de Custos passou a ser utilizada como ferramenta gerencial para tomada de decisão pelas organizações a partir da Revolução Industrial, durante o século XVIII, reconhecendo sua importância para aferição dos resultados econômicos (MARTINS, 2003).

Tal iniciativa possibilitou o uso da Contabilidade de Custos em outras áreas, como a Contabilidade Pública, e esse desenvolvimento no âmbito da Administração 
Pública no Brasil tomou força mediante a Lei $n^{\circ} 4.320$, de 1964 (BRASIL, 1964) e, posteriormente, com o Decreto Lei $\mathrm{n}^{\circ}$ 200, de 1967 (BRASIL, 1967), ambas estabeleceram que a administração pública deveria implementar sistema de custos, visando sua modernização (MONTEIRO, et al. 2010).

Esse Decreto, apesar de fortalecer o movimento reformista, não estabeleceu os instrumentos necessários para tornar essa reforma de fato gerencial (BRESSER PEREIRA, 1996).

Assim, o artigo 79 do Decreto Lei $n^{\circ} 200$ (BRASIL, 1967) foi regulado em 1986, através do Decreto Presidencial n93.872 (BRASIL, 1986), o qual detalhou a forma pela qual a contabilidade apuraria os custos dos serviços, e também determinou penalidades para os órgãos que não fornecessem informações relevantes para permitir as aferições dos resultados de custos (MONTEIRO, et al. 2010).

Posteriormente, a Lei Complementar no 101/2000 (BRASIL, 2000), denominada Lei de Responsabilidade Fiscal, reforçou a utilização de estudos de custos no setor público, através do art. 50, que determina que a "Administração Pública manterá sistema de custos que permita a avaliação e o acompanhamento da gestão orçamentária, financeira e patrimonial" (BRASIL, 2000).

Apesar da determinação legal para apuração dos custos no setor público, Monteiro et al (2010) apontam duas barreiras para sua utilização. Primeiramente, o fato de os dados de custos disponibilizados serem de difícil interpretação e geração de informação pelos usuários e, também, a tradição brasileira de dar ênfase aos controles financeiros em detrimento dos controles de produtividade.

Para auxiliar os órgãos da Administração Pública Federal a superar essas barreiras e cumprir as legislações pertinentes, a Secretaria do Tesouro Nacional STN - disponibilizou no ano de 2010 o Sistema de Informações de Custos do Governo Federal - SIC, que é uma ferramenta tecnológica que se utiliza da extração de dados dos sistemas estruturantes da administração pública federal.

No entanto, mesmo após a disponibilização do SIC, no âmbito das universidades federais, ainda é incipiente a utilização dos dados de custos consistentes para fins de tomada de decisão e melhoria da qualidade do gasto. Os motivos para esse fato podem ser a descontinuidade de programas e projetos de gestão, a prevalência da tomada de decisão baseada apenas em dados 
orçamentários, a desvalorização do profissional da contabilidade e o desconhecimento sobre as ferramentas do SIC.

Holanda, Lattman-Weltman e Guimarães (2010) afirmam que mediante um modelo de gestão gerencial moderno, o processo de tomada de decisão deve ser baseado no conhecimento das diferentes alternativas de ação, custos ou benefícios, do contrário poderá ocasionar gastos desnecessários aos cofres públicos.

Nesse pensamento, a implantação do Sistema de Informação de Custos do Governo Federal, os aprimoramentos nele realizados nos últimos anos e as condições de utilização e instruções dadas pelos treinamentos, tornaram a ferramenta, sobremaneira, mais acessível e didática aos usuários dos órgãos que o acessam, como as universidades federais. A UFRA, inserida nesse contexto, poderá usufruir de tal ferramenta.

A UFRA relata que nos últimos anos sua parcela do orçamento do Tesouro Nacional revela-se incompatível com as reais necessidades institucionais, influenciando no alcance das metas estabelecidas no Plano de Desenvolvimento Institucional - PDI. Ademais, o orçamento destinado ao custeio das suas atividades não é compatível e proporcional à reestruturação, expansão e interiorização obtida através do REUNI - Programa de Apoio a Planos de Reestruturação e Expansão das Universidades Federais (UNIVERSIDADE FEDERAL RURAL DA AMAZÔNIA, 2017b).

Mediante essa problemática, a presente pesquisa busca responder ao seguinte questionamento: Quais as ferramentas técnicas que podem auxiliar a UFRA em seu processo de implementação e utilização da sistemática de apuração de custos, considerando a obrigatoriedade legal da sua adoção?

\subsection{Justificativas}

Esta pesquisa justifica-se pela importância da utilização de mecanismos de controle do custo dos serviços e atividades desempenhadas pelo serviço público federal e possa atingir seu objetivo fundamental de servir à sociedade e atender suas demandas de forma que todos os recursos disponíveis sejam geridos de maneira eficiente.

A eficiência na gestão dos custos públicos possibilita a redução de desperdícios e estimula uma nova cultura de gasto dentro da instituição. A alocação 
adequada dos recursos disponíveis pode trazer para as organizações públicas o benefício de melhorar ou ampliar a oferta de serviços aos cidadãos.

Também é desafiador para as entidades governamentais estabelecer os preços públicos, taxas e tarifas, bem como o definir preço de venda de bens ou serviços oferecidos, para isso o conhecimento do custo dos produtos é primordial para que se determine o preço justo a ser cobrado à sociedade e também se consiga mensurar o resultado econômico obtido. A pesquisa de Romão (2007) denominada Proposta de Precificação de Serviço Público demonstra quão cruciais são as informações de custos para mensurar os preços das atividades e serviços públicos.

Nesse contexto, utilizando o SIC como ferramenta para análise das informações de custos da UFRA, além de atender as normas legais, será possível avaliar o desempenho de programas desenvolvidos pelo Governo Federal que nela funcionam, o que se faz necessário no cenário atual em razão da maior participação e interesse da sociedade na avaliação dos gastos públicos, até mesmo, opinando sobre que programas devem ser priorizados.

A partir da utilização do Sistema de Informações de Custos na UFRA, obedecendo às particularidades do perfil da instituição, será possível obter melhores resultados no processo alocativo, ou seja, avaliar se determinados serviços produzidos pelo órgão justificam os custos correspondentes, possibilitando a busca por alternativas que ofereçam custos aceitáveis.

O que torna ainda mais relevante o desenvolvimento da pesquisa em eficiência de gastos é a possibilidade de a UFRA destacar-se entre as demais universidades presentes na região amazônica, por apresentar procedimentos de gestão de nível excelente e demonstrar futuramente os resultados alcançados. Além disso, incentivar pesquisadores e profissionais a se aprofundarem no tema é outra justificativa para a realização da presente pesquisa.

Cabe ressaltar que as informações de custos passaram a ser exigidas pelo Tribunal de Contas da União (TCU) através do Relatório de Gestão que deve ser encaminhado anualmente por todas as Unidades Jurisdicionadas. Essa exigência demonstra que os recursos orçamentários e financeiros da Universidade precisam ser utilizados de forma racional.

A implantação da Gestão de Custos através da utilização do SIC contribuirá para elevar a avaliação institucional, promover a melhoria do ensino, da pesquisa e 
da extensão, e incentivar a sustentabilidade socioeconômica e ambiental na Amazônia, que é um dos pilares da missão da UFRA.

A utilização das informações de custos extraídas do SIC auxilia na análise da eficiência operacional através da verificação da relação custo x prestação de serviços. Também permitiria analisar comparativamente diversas maneiras de prestar os serviços com custos menores, ou seja, avaliar o custo x benefício. Assim, a implementação do SIC auxiliaria a identificar as atividades de baixo valor agregado que podem ser modificados e até mesmo eliminados (MACHADO; HOLANDA, 2010).

Negreiros et al. (2013) destaca que o Sistema de Custos é um recurso gerencial e que não somente as organizações privadas utilizam desse recurso, visto que a Contabilidade de Custos nas entidades públicas auxilia no controle e previne falhas orçamentárias, o que demanda práticas contábeis sofisticadas, pois há um paradigma que estabelece que as entidades públicas devem se auto sustentar e competir por recursos.

Em suma, o Sistema de Custos calcula e divulga os custos dos bens e serviços entregues à população, portanto, explorar esse tema continuamente incentivará aos gestores a analisar todas as informações adquiridas, buscando corrigir as distorções de classificação, tornar mais eficiente a utilização dos recursos públicos e avaliar o grau de desempenho da gestão.

A pesquisa justifica-se também, mediante os cortes orçamentários sofridos pelas Universidades nos últimos anos, o que provocou uma redução nos investimentos e gerou dificuldades no pagamento de despesas de custeio, portanto, gerando medidas essenciais no tratamento das despesas básicas para 0 funcionamento da instituição de ensino superior. Realizar contratações eficientes é uma medida que auxilia na alocação racional dos recursos recebidos. Mensurar a economia nas contratações realizadas na UFRA possibilita controlar os atos de gestão e seus resultados.

Torna-se necessário, mediante esse cenário adverso, não somente gerir o orçamento disponibilizado ao órgão, mas, controlar todos os custos imperiosos à manutenção da Universidade. O cenário ideal que se vislumbra é realizar de maneira efetiva todas as atividades planejadas, gastando-se melhor a parcela recebida do orçamento anual, e alavancar a avaliação da Universidade perante a sociedade e os órgãos de controle e fiscalização. 


\subsection{Objetivos}

\subsubsection{Objetivo Geral}

O objetivo geral desta pesquisa é apresentar ferramentas técnicas para a implementação e utilização de uma estrutura de gestão dos custos na Universidade Federal Rural da Amazônia - UFRA.

\subsubsection{Objetivos Específicos}

a) Apontar os aspectos legais e os principais benefícios da adoção das informações de custos para controle e melhoria da eficiência nas atividades exercidas pela UFRA.

b) Apresentar as melhores práticas de gestão de custos através da experiência de outros órgãos que utilizam um Sistema de Informações de Custos.

c) Demonstrar as ferramentas do Sistema de Informações de Custos do Governo Federal (SIC) para obtenção das informações de custos necessárias ao processo decisório por parte dos gestores da UFRA.

d) Propor modelos e estratégias para a utilização da Informação de Custos na UFRA.

\subsection{Organização da Pesquisa}

A presente dissertação se divide em cinco capítulos. No primeiro capítulo, introdutoriamente, são apresentados o problema de pesquisa, os objetivos e as justificativas para a pesquisa. No segundo capítulo é realizada a revisão da literatura. No terceiro capítulo estão demonstrados os procedimentos metodológicos utilizados e a pesquisa realizada. No quarto capítulo é realizada a análise dos dados, e por fim, no quinto capítulo, as conclusões obtidas mediante a pesquisa realizada. 


\section{REVISÃO DA LITERATURA}

\subsection{A Nova Gestão Pública e o Movimento de Reforma do Estado Brasileiro}

A reforma do Estado possui como característica principal a mudança do modelo burocrático de gestão transitando para um modelo de gestão flexível. Esse novo padrão gerencialista herdado da Nova Administração Pública, ou New Public Management, trouxe para o setor público um destaque maior para os aspectos econômico e gerencial.

Conforme Bresser Pereira (1996), a Administração Pública Burocrática ainda possuía indícios do Patrimonialismo e do enrijecimento burocrático, essa soma trazia como consequência o alto custo e a baixa qualidade da administração pública brasileira. Esse modelo foi adotado por ser uma alternativa superior à Administração Patrimonialista do Estado, entretanto, se esperava que os pressupostos da eficiência se fizessem mais presentes. O que se verificou foi o inverso, não havia garantia de rapidez, nem boa qualidade, nem custos baixos para os serviços prestados ao público. Ou seja, a Administração burocrática se mostrou lenta, cara, e sem orientação para o atendimento das necessidades da população. Tais características trouxeram a necessidade de mudanças através da administração pública gerencial.

Essas mudanças advieram dos desejos da sociedade por uma gestão mais transparente, que forneça o máximo de informações sobre os dispêndios públicos e os seus benefícios correspondentes. Tal disposição de dados, como forma de prestação de contas à sociedade, denominada accountability, proporciona abertura para maior participação dos cidadãos no controle de gastos do Estado e permite, no decorrer desse processo, a inclusão de novos atores sociais nas etapas de formulação e acompanhamento das políticas públicas (HOLANDA; LATTMANWELTMAN; GUIMARÃES, 2010).

De acordo com Costa Júnior (2016) os debates relacionados à reforma do Estado se direcionam aos fundamentos da lógica gerencial buscando alcançar altos níveis de eficiência relacionada ao uso dos recursos públicos. Esta lógica compartilha, pelo menos, três propósitos fundamentais: Garantir a otimização constante do uso dos recursos públicos na produção e distribuição de bens públicos como resposta aos apelos dos cidadãos por melhores serviços, redução de impostos, eficácia e eficiência, equidade e qualidade; Desenvolver mecanismos para 
que a produção de bens e serviços públicos seja realizada de forma transparente, equitativa e controlável, e; Buscar estímulos internos para aumentar o desempenho dos dirigentes e servidores públicos, e, consequentemente, alavancar a efetividade dos organismos governamentais, visando à concretização dos objetivos citados anteriormente.

Costa Júnior (2016) afirma que esses propósitos, de maneira geral, visam à melhoria dos resultados das ações decorrentes do desempenho governamental. Trata-se, portanto, de uma prática de orientação às organizações públicas, para que trabalhem em cima dos aspectos que possam interferir nos índices de eficiência do ente público.

Nesse contexto, Pigatto. et al. (2010, p. 823) menciona que alguns países passaram a discutir e a aderir ao movimento da nova administração pública a partir da década de 1980. Dessa forma, o movimento da nova administração pública veio propor modificações na participação do Estado, cobrando alterações na forma de apresentação das informações financeiras e maior rigor quanto à responsabilidade na gestão fiscal.

Essa proposta de alteração do papel do Estado requereu um modelo diferente de informação financeira nos países aderentes. Como exemplo, nos países como a Nova Zelândia e a Espanha ocorreram mudanças paradigmáticas caracterizadas significativamente pela reforma contábil. As implicações da nova administração pública em relação às implicações contábeis estão sintetizadas no quadro 1 .

Quadro 1 - Implicações da nova administração pública na gestão financeira

\begin{tabular}{|l|l|}
\hline \multicolumn{1}{|c|}{ Características da nova administração pública } & \multicolumn{1}{c|}{ Implicações Contábeis } \\
\hline Foco nos resultados & Contabilidade dos custos \\
\hline Administração fundamentada na do setor privado & Medidas de desempenho \\
\hline Ênfase na economia e redução de custos & Orçamento \\
\hline Descentralização & $\begin{array}{l}\text { Informação comparativa } \\
\text { Contas consolidadas } \\
\text { Informação Uniforme } \\
\text { Auditoria de desempenhos }\end{array}$ \\
\hline Competitividade & $\begin{array}{l}\text { Informação Comparativa } \\
\text { Contabilidade de Custos } \\
\text { Evidenciação }\end{array}$ \\
\hline Orientação para o cidadão & Informação de fácil compreensão \\
\hline
\end{tabular}

Fonte: Pigatto et al. (2010, p. 824) 
A Nova Administração Pública apresentam a contabilidade de custos como um instrumento necessário à apuração de resultados e importante para aferir o nível de competitividade das atividades desempenhadas pelo governo. Demonstra que é uma ferramenta que auxiliará as entidades governamentais a alcançar o nível almejado de eficiência.

Tratando a eficiência sob a égide dos custos e da avaliação de políticas públicas, será um indicador que analisará o rendimento do serviço prestado ou do bem adquirido considerando o seu custo. Ou seja, avalia a menos relação custo versus benefício para o alcance dos objetivos estabelecidos para o programa executado (Machado, 2002).

Ao tratar de eficiência, cabe ressaltar que, como consequência do movimento reformista, em 1988, a Constituição Federal Brasileira (BRASIL, 1988) institucionalizou os princípios fundamentais da Administração Pública, dentre os quais destaca-se o Princípio da Eficiência em razão da sua relação direta com a proposta de utilização de um sistema gerencial para aperfeiçoamento da aplicação e melhoria dos controles dos recursos públicos.

Ainda nesse sentido, no ano 2000, em meio ao auge da crise fiscal brasileira foi promulgada a Lei Complementar n 101, denominada Lei de Responsabilidade Fiscal - LRF (BRASIL, 2000). A LRF no inciso I, do Artigo 4ํㅜㄹ fixa uma série de restrições sobre o gasto público no curto prazo e impôs mecanismos para o controle de custos e avaliação dos programas financiados com recursos dos orçamentos (PIGATTO et al, 2010).

Pigatto et al (2010) observa que as exigências ora impostas demonstravam uma nova preocupação relacionada à sustentabilidade da política fiscal no longo prazo, entretanto, nem a LRF (BRASIL, 2000), nem o Decreto-lei no 200 (BRASIL, 1967) indicavam de maneira clara os meios necessários para apurar a informação de custo, o que veio a ser sanado posteriormente. Ademais, nesses normativos também não tinham sido consideradas as limitações decorrentes, principalmente, do escopo do regime contábil preconizado pela lei geral de finanças, a Lei $n 4.320$, de 1964 (BRASIL, 1964).

As adversidades apresentadas relacionadas à apuração de custos e melhoria da eficiência dos serviços públicos foram sendo minimizadas ao longo dos anos através das legislações e normas específicas para tratar de custos do setor público e suas implicações. Corroborado, também, pela publicação em 25 de novembro de 
2011 da Resolução CFC n 1.366/11 que aprova a Norma Brasileira de Contabilidade NBC T 16.11 - Sistema de Informação de Custo do Setor Público e posteriormente, pela homologação do Sistema de Informação de Custos do Governo Federal - SIC, ferramenta cuja finalidade é auxiliar os gestores nas decisões sobre alocação de recursos e prestações de contas (CONSELHO FEDERAL DE CONTABILIDADE, 2012).

\subsection{Contabilidade de Custos no Setor Público}

Para que o estudo de custos no setor público chegasse ao patamar atual, a Contabilidade de Custos primeiramente ganhou importância dentro das grandes indústrias, principalmente em decorrência das oportunidades originadas pela Revolução Industrial (século XVIII), pois as informações de custos passaram a ser utilizadas como uma forma de auxílio no desempenho das funções gerenciais. Assim, Martins (2003) menciona que ela possui duas funções relevantes: o auxílio ao Controle e a ajuda às tomadas de decisões.

No que se refere ao Controle, a sua missão é fornecer dados para estabelecer padrões, orçamentos e outras formas de previsão, para que se possa acompanhar o efetivamente acontecido e realizar as comparações, ou seja, avaliar o cumprimento das metas estabelecidas previamente. Quanto à tomada de decisões, seu papel é alimentar as informações relevantes sobre os impactos de curto e longo prazo nas decisões sobre inserção ou corte de produção, administração de preços de compra e venda, etc. (MARTINS, 2003).

Ademais, fatores como o desenvolvimento dessas empresas, o aumento da competitividade, o distanciamento hierárquico entre o dono (ou administrador) e as pessoas administradas, fizeram com que a Contabilidade de Custos se tornasse um instrumento de gestão eficiente, passando a ser caracterizada como contabilidade gerencial (MARTINS, 2003).

A Contabilidade de Custos é a fonte das informações da Contabilidade Gerencial e Financeira, pois ela mede e demonstra informações de cunho financeiro e/ou não-financeiro relacionadas aos recursos utilizados em uma entidade. A gestão dos custos voltada para as decisões de planejamento e controle de curto e longo prazos ajudam a agregar valor aos clientes e reduzir custos operacionais da entidade (SANTOLIN, 2017). 
Santolin (2017) reforça que a Contabilidade de Custos é uma atividade que produz dados sobre custos para aqueles que farão uso dessas informações. A partir daí, a gestão desses custos poderá balizar as etapas de planejamento na entidade, e também poderá auxiliar nas etapas posteriores de execução e controle conforme a necessidade dos usuários.

Figura 1: Contabilidade Financeira, de Custos e Gerencial

\begin{tabular}{|c|c|c|c|}
\hline & $\begin{array}{l}\text { CONTABILIDADE } \\
\text { FINANCEIRA }\end{array}$ & \multirow[b]{2}{*}{$\begin{array}{l}\text { CONTABILIDADE } \\
\text { DE CUSTOS }\end{array}$} & $\begin{array}{l}\text { CONTABILIDADE } \\
\text { GERENCIAL }\end{array}$ \\
\hline 1. Público alvo & $\begin{array}{l}\text { Externo à organização (acionistas, sócios, } \\
\text { credores, legisladores, etc.). }\end{array}$ & & $\begin{array}{l}\text { Interno à organização (gestores, } \\
\text { controladores, etc.). }\end{array}$ \\
\hline 2. Foco temporal & $\begin{array}{l}\text { Ênfase nas consequências financeiras das } \\
\text { atividades passadas. }\end{array}$ & \multirow{3}{*}{$\begin{array}{l}\text { - Dados levantados a } \\
\text { partir de registros da } \\
\text { contabilidade } \\
\text { financeira. }\end{array}$} & $\begin{array}{l}\text { Ênfase nas decisões que afetam o } \\
\text { futuro. }\end{array}$ \\
\hline 3. Dados & $\begin{array}{l}\text { Ênfase na objetividade e consistência dos } \\
\text { dados. }\end{array}$ & & $\begin{array}{l}\text { Ênfase na relevância e flexibilidade } \\
\text { dos dados. }\end{array}$ \\
\hline $\begin{array}{l}\text { 4. Natureza da } \\
\text { informação }\end{array}$ & Informação precisa. & & Ênfase na Oportunidade. \\
\hline 5. Relatórios & $\begin{array}{l}\text { Resumidos e rígidos, em certo grau; } \\
\text { orientação histórica. }\end{array}$ & \multirow{4}{*}{$\begin{array}{l}\text { - Subsídio à } \\
\text { contabilidade } \\
\text { gerencial. }\end{array}$} & $\begin{array}{l}\text { Flexíveis e detalhados; orientação } \\
\text { histórica e para o futuro. }\end{array}$ \\
\hline 6. Regras & $\begin{array}{l}\text { Observância aos Princípios de } \\
\text { Contabilidade }\end{array}$ & & $\begin{array}{l}\text { Não-obrigatoriedade de observância } \\
\text { aos princípios de contabilidade. }\end{array}$ \\
\hline 7. Obrigatoriedade & Obrigatória. & & Não-obrigatória. \\
\hline 8. Auditoria & Externa e interna & & - \\
\hline
\end{tabular}

Fonte: Brasil. Secretaria do Tesouro Nacional (2017d, p. 7).

A Contabilidade Gerencial, conforme Neves e Vicenconti (2003), passou a ser auxiliada pela Contabilidade de Custos através das duas funções mencionadas anteriormente, o auxílio ao controle e à tomada de decisão. No quadro 2 são mencionados exemplos dessas decisões gerenciais nas empresas privadas que os autores consideram que podem ser tomadas através dos dados de custos.

Quadro 2: Decisões baseadas nas informações de custos nas empresas privadas

\begin{tabular}{l} 
Se a capacidade de produção da fábrica e insuficiente para atender todos os pedidos dos \\
clientes, qual produto ou linha de produtos deve ser cortado? \\
\hline Como fixar preços de venda de um produto? \\
\hline Comprar matérias-primas de terceiros ou fabricá-las na própria empresa? \\
\hline Deve-se comprar equipamento novo ou reformar o antigo? \\
\hline Aceitar pedido de compra do exterior a um preço inferior ao de venda no mercado interno? \\
\hline Quais são os produtos da empresa que lhe dão lucro ou prejuízo?
\end{tabular}

Fonte: Neves e Viceconti (2003, p. 8). 
Neves e Viceconti (2003) afirmam que a Contabilidade Gerencial e a Contabilidade de Custos visam atender às necessidades dos usuários internos da empresa, que não é preciso levar em conta de forma rígida os princípios contábeis geralmente aceitos, assim as informações serão fornecidas em um formato que atenda o interesse dos administradores, ou seja, os tomadores de decisão.

Quanto aos exemplos de decisões mencionados no quadro 2, apesar de fazerem parte de um contexto empresarial, também servem de base para impulsionar a criação de ferramentas de custos no âmbito das organizações públicas.

Em órgãos públicos, considerando as suas finalidades distintas das organizações privadas, a Contabilidade de Custos serviria para tomar decisões a respeito:

- Dos serviços prestados à comunidade, se estão sendo realizados dentro de parâmetros pré-estabelecidos de eficiência, eficácia e efetividade;

- Das formas de aquisição de materiais e equipamentos e contratações de serviços, se são as alternativas disponíveis no mercado com maior vantajosidade, considerando qualidade e benefícios;

- Dos preços dos serviços cobrados à sociedade, se estão dentro de uma razoabilidade entre os custos necessários para a prestação dos serviços, natureza do serviço e o desembolso pelo consumidor;

- Do nível de eficiência das unidades administrativas, através de comparações com outras unidades internas ou de unidades pertencentes a órgãos da mesa natureza; etc.

A Contabilidade de Custos pode ser utilizada por organizações de qualquer ramo sejam industriais, prestações de serviços, comércio e organizações sem fins lucrativos. O que deve haver em comum entre os gestores dessas organizações é a preocupação com a otimização dos recursos a serem gastos mediante utilização de um sistema de controle que possa auxiliá-Ios (MARTINS, 2003).

Conforme Martins (2003), a partir do reconhecimento da importância da utilização e eficiência das informações fornecidas pela Contabilidade de Custos, organizações e empresas não industriais passaram a explorar os Custos como ferramenta gerencial, buscando aumentar seu potencial para um melhor controle de sua gestão e, principalmente, para as tomadas de decisões organizacionais. Surge 
daí o embrião do estudo de custos aplicados ao setor público, bem como a necessidade de criação de um sistema de informação que auxilie essa análise.

Portanto, o desenvolvimento da Contabilidade Gerencial deu importância às informações de custos considerando sua necessidade de uso para tomadas de decisão. Essa modernização do perfil da Contabilidade de Custo possibilitou sua entrada em outros campos como, por exemplo, a Contabilidade Pública. Um exemplo desta transformação é o desenvolvimento da Contabilidade de Custos no âmbito da Administração Pública no Brasil (OLIVEIRA, 2012).

Negreiros et al. (2013) afirma que o principal objetivo da administração pública não é a obtenção de lucros como nas organizações privadas e que o uso de um sistema de custos nesses tipos de organizações está voltado para a melhor aplicação de recursos, o que significa promover distribuição eficiente dos gastos públicos para oferecer mais e melhores serviços aos cidadãos.

A ação de controlar segundo Martins (2003) é a "forma de se conhecer a realidade, compará-la com o que deveria ser, tomar conhecimento rápido das divergências e suas origens e tomar atitudes para sua correção". O autor afirma que esse conceito pode ser aplicado inclusive ao setor público. Ademais, pode-se dizer que a organização tem controle dos seus custos quando os conhece, verifica se estão dentro do planejado, analisa as divergências e pratica medidas de correção dos desvios. Também alerta sobre a relevância e necessidade de possuir o Sistema de Custos para obtenção de controle nas organizações, e que o sucesso das informações depende principalmente do pessoal que está envolvido com o sistema.

Conforme Alonso (1999) "a importância do tema 'custos no serviço público' pode ser avaliada pelo crescente número de iniciativas governamentais em vários países na última década e pelo espaço que vem ganhando na literatura especializada". A iniciativa da administração pública federal americana à época do Governo de Bill Clinton foi um dos modelos mais utilizados em razão do nível avançado e sua abrangência.

No Brasil, o controle da gestão das finanças públicas passou a avançar principalmente a partir do ano de 1986 com a criação da Secretaria do Tesouro Nacional, vinculada ao Ministério da Fazenda, e o desenvolvimento e implantação do SIAFI (Sistema Integrado de Administração Financeira). O Brasil passou a ser reconhecido como referência internacional no controle informatizado de gastos governamentais em razão das ferramentas trazidas pelo SIAFI. 
Quanto ao aspecto legal do uso da informação de custos no Brasil, mencionamos anteriormente a Lei $n^{\circ} 4320$ de 1964 (BRASIL, 1964), o Decreto Lei $n^{\circ}$ 200 (BRASIL,1967) e a Lei de Responsabilidade Fiscal (BRASIL, 2000), entretanto, outras legislações foram publicadas para corroborar a necessidade de controlar e mensurar custos para alcance da eficiência no setor público, conforme resumo no quadro 3.

Quadro 3: A obrigatoriedade do uso de informação de custos na legislação brasileira

\begin{tabular}{|c|c|}
\hline Normativo & Dispositivo Legal \\
\hline Lei № 4.320/1964 & $\begin{array}{l}\text { Art. 85. Os serviços de contabilidade serão organizados de forma a permitirem } \\
\text { o acompanhamento da execução orçamentária, o conhecimento da } \\
\text { composição patrimonial, a determinação dos custos dos serviços industriais, } \\
\text { o levantamento dos balanços gerais, a análise e a interpretação dos } \\
\text { resultados econômicos e financeiros. } \\
\text { Art. } 99 \text {. Os serviços públicos industriais, ainda que não organizados como } \\
\text { empresa pública ou autárquica, manterão contabilidade especial para } \\
\text { determinação dos custos, ingressos e resultados, sem prejuízo da } \\
\text { escrituração patrimonial e financeira comum. }\end{array}$ \\
\hline $\begin{array}{l}\text { Decreto-Lei } \\
200 / 1967\end{array}$ & $\begin{array}{l}\text { Art. 79. A contabilidade deverá apurar os custos dos serviços de forma a } \\
\text { evidenciar os resultados da gestão. }\end{array}$ \\
\hline $\begin{array}{l}\text { Decreto } \\
93.879 / 1986\end{array}$ & $\begin{array}{l}\text { Art. 137. "A contabilidade deverá apurar o custo dos projetos e atividades, de } \\
\text { forma a evidenciar os resultados da gestão". }\end{array}$ \\
\hline $\begin{array}{l}\text { Lei Complementar } \\
\text { № } 101 / 2000\end{array}$ & $\begin{array}{l}\text { Art. 50. § 30 - A Administração Pública manterá sistema de custos que } \\
\text { permita a avaliação e o acompanhamento da gestão orçamentária, financeira } \\
\text { e patrimonial; } \\
\text { Art. 59. O Poder Legislativo, diretamente ou com o auxílio dos Tribunais de } \\
\text { Contas, e o sistema de controle interno de cada Poder e do Ministério Público, } \\
\text { fiscalizarão o cumprimento das normas desta Lei Complementar, com ênfase } \\
\text { no que se refere a: (...) V - fatos que comprometam os custos ou os } \\
\text { resultados dos programas ou indícios de irregularidades na gestão } \\
\text { orçamentária. }\end{array}$ \\
\hline $\begin{array}{l}\text { Lei № } \\
10.180 / 2001\end{array}$ & $\begin{array}{l}\text { Art. 15. Item } \mathrm{V} \text { - os custos dos programas e das unidades da Administração } \\
\text { Pública Federal; } \\
\text { Art. } 35 . \S 1^{\circ} \text { Ao fixarem os valores a serem transferidos, conforme o disposto } \\
\text { neste artigo, os entes nele referidos farão análise de custos, (...). }\end{array}$ \\
\hline $\begin{array}{l}\text { Acórdão № } \\
1078 / 2004 \text { do } \\
\text { TCU }\end{array}$ & $\begin{array}{l}\text { Determina a adoção de providências para que a administração pública federal } \\
\text { possa dispor com a maior brevidade possível de sistemas de custos, que } \\
\text { permitam, entre outros, a avaliação e o acompanhamento da gestão } \\
\text { orçamentária e financeira. }\end{array}$ \\
\hline $\begin{array}{l}\text { Portaria } \\
\text { Interministerial } \\
945 / 2005\end{array}$ & $\begin{array}{l}\text { Constituir Comissão para elaborar estudos e propor diretrizes, métodos e } \\
\text { procedimentos, para subsidiar a implantação do sistema de custos na } \\
\text { Administração Pública Federal. }\end{array}$ \\
\hline $\begin{array}{l}\text { Res. CFC } \\
1133 / 2008\end{array}$ & $\begin{array}{l}\text { Art. } 2^{\circ} \text {. Item } 36 \text {. A Demonstração do Resultado Econômico deve ser elaborada } \\
\text { considerando sua interligação com o sistema de custos e apresentar na } \\
\text { forma dedutiva, pelo menos, a seguinte estrutura: (...) (b) custos e despesas } \\
\text { identificados com a execução da ação pública. }\end{array}$ \\
\hline $\begin{array}{l}\text { Decreto } \\
\text { № } 6.976 / 2009\end{array}$ & $\begin{array}{l}\text { Art. 3o O Sistema de Contabilidade Federal tem por finalidade, utilizando as } \\
\text { técnicas contábeis, registrar os atos e fatos relacionados com a administração } \\
\text { orçamentária, financeira e patrimonial da União e evidenciar: (...) VI - os } \\
\text { custos dos programas e das unidades da administração pública federal. } \\
\text { Art. } 7^{\circ} \text { Compete ao órgão central do Sistema de Contabilidade Federal: (...) } \\
\text { XIX - manter sistema de custos que permita a avaliação e o } \\
\text { acompanhamento da gestão orçamentária, financeira e patrimonial. }\end{array}$ \\
\hline
\end{tabular}




\begin{tabular}{|c|c|}
\hline Normativo & \begin{tabular}{|c|c|} 
Dispositivo Legal & (Conclusão) \\
\end{tabular} \\
\hline $\begin{array}{l}\text { Decreto } \\
\text { № } 7386 / 2010\end{array}$ & $\begin{array}{l}\text { Art. 21. À Subsecretaria de Contabilidade Pública compete: (...)VII - manter } \\
\text { sistema de custos que permita a avaliação e o acompanhamento da gestão } \\
\text { orçamentária, financeira e patrimonial. }\end{array}$ \\
\hline $\begin{array}{l}\text { Portaria } \\
157 / 2011\end{array}$ & $\begin{array}{l}\text { Art. 1 Fica criado o Sistema de Custos no âmbito do Governo Federal. } \\
\text { Art. } 2 \text { o O Sistema de Custos do Governo Federal visa a evidenciar os custos } \\
\text { dos programas e das unidades da administração pública federal. }\end{array}$ \\
\hline $\begin{array}{l}\text { Portaria STN } \\
716 / 2011\end{array}$ & $\begin{array}{l}\text { Art. 30 Compete aos Órgãos Setoriais do Sistema de Custos do Governo } \\
\text { Federal: } \\
\text { II - Prestar apoio, assistência e orientação na elaboração de relatórios } \\
\text { gerenciais do Sistema de Informações de Custos - SIC das unidades } \\
\text { administrativas e entidades subordinadas; } \\
\text { X - Promover a disseminação das informações de custos nas entidades } \\
\text { subordinadas; }\end{array}$ \\
\hline $\begin{array}{l}\text { Resolução CFC Nº } \\
1.366 / 2011\end{array}$ & $\begin{array}{l}\text { Art. 1 Aprovar a NBC T } 16.11 \text { - Sistema de Informação de Custos do Setor } \\
\text { Público. } \\
\text { Art. } 2^{\circ} \text { Esta Resolução entra em vigor na data de sua publicação, aplicando-se } \\
\text { aos exercícios iniciados a partir de } 1^{\circ} \text { de janeiro de } 2012 \text {. A entidade que } \\
\text { esteja sujeita a legislação que estabeleça prazo distinto para início da sua } \\
\text { adoção pode adotar esta Norma a partir do prazo estabelecido por aquela } \\
\text { legislação. }\end{array}$ \\
\hline $\begin{array}{l}\text { Portaria STN } \\
437 / 2012\end{array}$ & $\begin{array}{l}\text { Art. 6- Parte II (Procedimentos Contábeis Patrimoniais) deverá ser adotada } \\
\text { pelos entes da Federação gradualmente até o final do exercício de } 2014 \text {, salvo } \\
\text { na existência de legislação específica emanada pelos órgãos de controle que } \\
\text { antecipe este prazo, observados os seguintes aspectos (Portaria STN } n^{\circ} \\
828 / 2011) \text { : } \\
\text { (...)VI - Implementação do sistema de custos; }\end{array}$ \\
\hline $\begin{array}{l}\text { Portaria STN } \\
634 / 2013\end{array}$ & 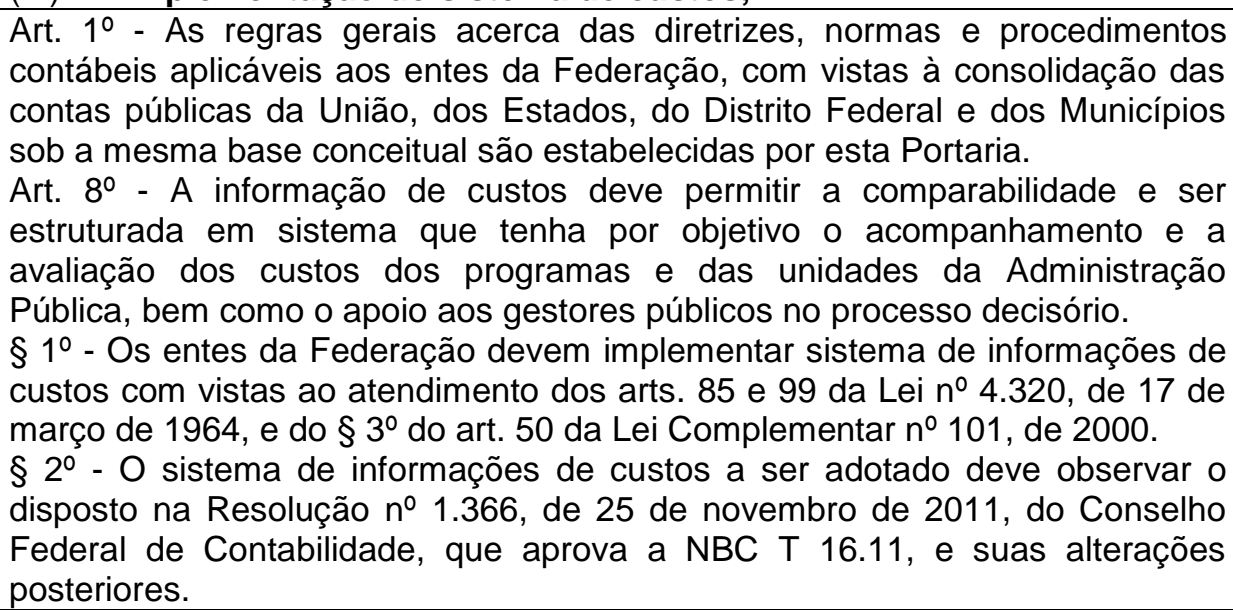 \\
\hline $\begin{array}{l}\text { Resolução CFC No } \\
1.437 / 2013\end{array}$ & $\begin{array}{l}\text { Art. 5o Alterar a NBC T } 16.11 \text { - Sistema de Informação de Custos do Setor } \\
\text { Público, aprovada pela Resolução CFC n.o } 1.366 / 11 \text {, publicada no D.O.U., } \\
\text { Seção I, de } 2 / 12 / 11 \text {, como segue: (a) dar nova redação às definições "Custo } \\
\text { variável" e "Custo padrão (standard)" do item } 9 \text {. }\end{array}$ \\
\hline
\end{tabular}

Fonte: Adaptado de Elias (2018, p. 43-46) e Monteiro et al (2011, p. 4-5).

É importante frisar que as mudanças ocorridas na Contabilidade Pública através da publicação das Novas Normas Brasileiras de Contabilidade Aplicadas ao Setor Público (NBCASP) a partir de 2008, também foi um fator que impulsionou de maneira significativa os estudos de custos no setor público.

Costa Junior (2016) explica que a Contabilidade Pública no Brasil passa por um período de transição no qual o caráter orçamentário passou a dar espaço à 
evidenciação dos fenômenos patrimoniais e ao tratamento contábil padronizado dos atos e fatos administrativos no âmbito do setor público.

O quadro 4 compara as especificidades dessa nova visão da contabilidade pública que busca evidenciar o patrimônio, com a visão da legalidade orçamentária, posto que são ações importantes, porém, com objetivos diferentes.

Quadro 4 - Legalidade Orçamentária versus Evidenciação do Patrimônio

\begin{tabular}{|c|c|}
\hline $\begin{array}{c}\text { Ações de Verificação da Legalidade } \\
\text { Orçamentária } \\
\text { Base Legal: Lei № } 4320 / 64\end{array}$ & $\begin{array}{l}\text { Ações da Avalição da Evidenciação do } \\
\text { Patrimônio } \\
\text { Base Legal: Lei № } 4320 / 64 \text { e NBCASP }\end{array}$ \\
\hline $\begin{array}{l}\text { a) Art.75. O controle da execução orçamentária } \\
\text { compreenderá: } \\
>\text { A legalidade dos atos que resultem a } \\
\text { arrecadação da receita ou a realização } \\
\text { de despesa, o nascimento ou a extinção } \\
\text { de direitos e obrigações; } \\
\text { A fidelidade funcional dos agentes da } \\
\text { administração, responsáveis por bens e } \\
\text { valores públicos; } \\
\text { O cumprimento do programa de } \\
\text { trabalho expresso em termos } \\
\text { monetários e em termos de realização } \\
\text { de obras e prestação de serviços. } \\
\text { b) Art.77. Ações de controle da legalidade } \\
\text { orçamentária: } \\
>\text { Prévia; } \\
>\text { Concomitante; e } \\
>\text { Subsequente. }\end{array}$ & $\begin{array}{l}\text { a) Art. 89. A contabilidade evidenciará os fatos } \\
\text { ligados à administração orçamentária, } \\
\text { financeira, patrimonial e industrial. } \\
\text { b) NBC T - Ações da avaliação de controle } \\
\text { patrimonial: } \\
>\text { Avaliação prévia ou ex-ante; } \\
>\text { Avaliação concomitante: } \\
>\text { Avaliação a meio caminho (Balanço } \\
\text { Patrimonial e Demonstração das } \\
\text { variações patrimoniais); } \\
>\text { Avaliação subsequente ou ex-post. }\end{array}$ \\
\hline
\end{tabular}

Fonte: Adaptado de Costa Junior (2016, p. 24).

Ao tratar sobre avaliação de controle patrimonial, prévia, concomitante, a meio do caminho e subsequente, a NBC T veio ratificar a necessidade da utilização de ferramenta de mensuração e avaliação de custos. Nesse contexto, a necessidade de aprimoramento no controle de gastos públicos ganhou destaque também devido ao aumento da complexidade das organizações públicas e à importância das informações de custos nessas entidades.

Apesar do quadro 4 retratar que a evidenciação dos fenômenos patrimoniais vem ganhando espaço em detrimento das ações de verificação da Legalidade Orçamentária, cabe ressaltar que a melhoria da avaliação dos gastos públicos perpassa pelo fortalecimento da contabilidade e orçamento, assim como o aprimoramento da informação de custos e do processo orçamentário conforme retrata a figura 2 elaborada por Holanda, Lattman-Weltman e Guimarães (2010). 
Figura 2: Circulo Virtuoso da Contabilidade Pública

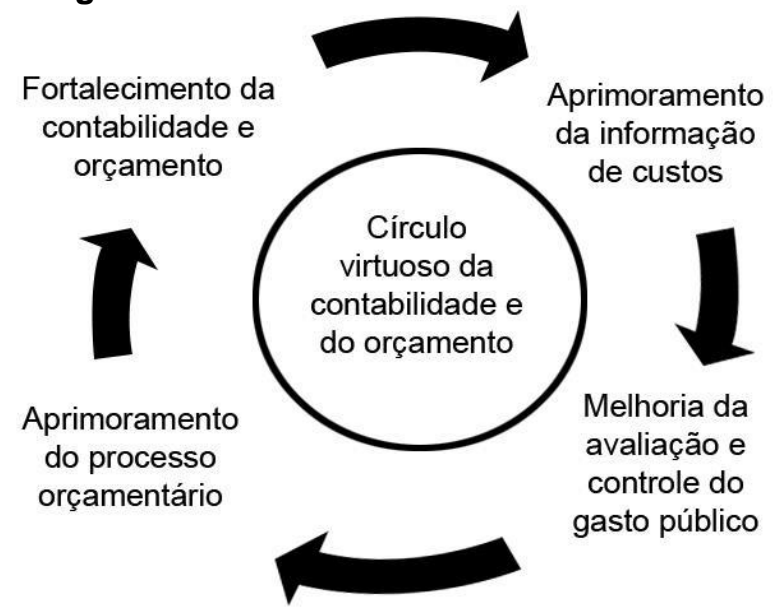

Fonte: Holanda, Lattman-Weltman e Guimarães (2010, p. 126)

De posse das informações de custos da máquina estatal, os gestores podem tomar providências para melhorar a qualidade do gasto público. Ademais, a população também terá dados suficientes para questionamentos e pressionar os gestores a tomar as providências necessárias para a melhoria dos serviços públicos oferecidos. Essa medida possibilita melhor controle da população sobre as prioridades na utilização dos recursos públicos em relação à qualidade dos serviços, caminhando para tendência de aumentar a transparência do gasto público (REZENDE, CUNHA, e BEVILACQUA, 2010).

Nesse contexto, pode-se dizer que ao conhecer os custos das políticas e programas executados pelo setor público é possível saber se o dinheiro do contribuinte, oriundo de pagamento de impostos, está sendo bem utilizado. Para isso, é possível, por exemplo, comparar custos vinculados ao desempenho escolar, analisando se há melhoria no desempenho escolar e se está sendo obtida ao menor custo possível ou se há indícios de desperdício, ou se com o mesmo recurso aplicado se poderiam obter melhores resultados (NEGREIROS et al., 2013).

Outro fator de contribuição aos mecanismos de controle de custos no setor público foi a publicação da Resolução do Conselho Federal de Contabilidade № 1.366/11 em 25 de novembro de 2011 que aprova a Norma Brasileira de Contabilidade NBC T 16.11 - Sistema de Informação de Custos do Setor Público SICSP (CONSELHO FEDERAL DE CONTABILIDADE, 2012). 
A NBC T 16.11 trata sobre a conceituação, o objeto, os objetivos e as regras básicas para mensuração e evidenciação dos custos no setor público, portanto, ela estabelece parâmetros para que os custos de bens e serviços produzidos e oferecidos à sociedade pelas entidades públicas possam ser registrados, processados e evidenciados (PACELLI, 2018).

A Norma menciona que o Sistema de Informação de Custo do Setor Público (SICSP) é obrigatório em todas as entidades do setor público. Essa obrigatoriedade decorre da relevância para o interesse público, seja do ponto de vista legal ou da sua utilidade. Do ponto de vista legal, os dispositivos citados neste trabalho determinam a apuração de custos no setor público tanto como ferramenta de transparência e prestação de contas, seja para controle interno, externo ou controle social. Do ponto de vista da utilidade, destaca-se o valor da informação de custos para fins gerenciais e para tomada de decisão.

De modo geral, os objetivos do SICSP definidos pela NBC T 16.11 (CONSELHO FEDERAL DE CONTABILIDADE, 2012) são:

a) mensurar, registrar e evidenciar os custos dos produtos, serviços, programas, projetos, atividades, ações, órgãos e outros objetos de custos da entidade;

b) apoiar a avaliação de resultados e desempenhos, permitindo a comparação entre os custos da entidade com os custos de outras entidades públicas, estimulando a melhoria do desempenho dessas entidades;

c) apoiar a tomada de decisão em processos, tais como comprar ou alugar, produzir internamente ou terceirizar determinado bem ou serviço;

d) apoiar as funções de planejamento e orçamento, fornecendo informações que permitam projeções mais aderentes à realidade com base em custos incorridos e projetados;

e) apoiar programas de controle de custos e de melhoria da qualidade do gasto.

O alcance desses objetivos está condicionado a alguns fatores como 0 tratamento conceitual adequado, abordagem tecnológica apropriada para atuar com dimensões temporais, numéricas e organizacionais, etc., permitindo a análise de séries históricas de custos sob a ótica das atividades-fim ou administrativas do setor público (NBC T 16.11). Além desses fatores há o uso de ferramentas que viabilizem acesso rápido aos bancos de dados, de forma que a criação de relatórios e a análise dos dados sejam facilitados. 
Para facilitar a leitura e entendimento, a Norma define alguns significados e definições de termos próprios da contabilidade de custos, conforme quadro 5 :

Quadro 5: Termos relacionados ao SICSP

\begin{tabular}{|c|c|}
\hline Objeto de custo & $\begin{array}{l}\text { É a unidade que se deseja mensurar e avaliar os custos. Os principais } \\
\text { objetos de custos são identificados a partir de informações dos } \\
\text { subsistemas orçamentário e patrimonial. }\end{array}$ \\
\hline $\begin{array}{l}\text { Informações do } \\
\text { Subsistema orçamentário }\end{array}$ & $\begin{array}{l}\text { A dimensão dos produtos e serviços prestados; função, atividades, } \\
\text { projetos, programas executados; centros de responsabilidade - } \\
\text { poderes e órgãos, identificados e mensurados a partir do planejamento } \\
\text { público, podendo se valer, ou não, das classificações orçamentárias } \\
\text { existentes. }\end{array}$ \\
\hline $\begin{array}{l}\text { Informações do } \\
\text { Subsistema patrimonial }\end{array}$ & $\begin{array}{l}\text { A dimensão dos produtos e serviços prestados, identificados e } \\
\text { mensurados a partir das transações quantitativas e qualitativas afetas } \\
\text { ao patrimonial da entidade consoante os Princípios de Contabilidade. }\end{array}$ \\
\hline Apropriação do custo & $\begin{array}{l}\text { É o reconhecimento do gasto de determinado objeto de custo } \\
\text { previamente definido. }\end{array}$ \\
\hline Gasto & $\begin{array}{l}\text { é o dispêndio de um ativo ou criação de um passivo para obtenção de } \\
\text { um produto ou serviço. }\end{array}$ \\
\hline Desembolso & é o pagamento resultante da aquisição do bem ou serviço. \\
\hline Investimento & $\begin{array}{l}\text { corresponde ao gasto levado para o Ativo em função de sua vida útil. } \\
\text { São todos os bens e direitos adquiridos e registrados no ativo. }\end{array}$ \\
\hline Perdas & $\begin{array}{l}\text { correspondem a reduções do patrimônio que não estão associadas a } \\
\text { qualquer recebimento compensatório ou geração de produtos ou } \\
\text { serviços, que ocorrem de forma anormal e involuntária. }\end{array}$ \\
\hline Custos & $\begin{array}{l}\text { são gastos com bens ou serviços utilizados para a produção de outros } \\
\text { bens ou serviços. }\end{array}$ \\
\hline $\begin{array}{l}\text { Custos da prestação de } \\
\text { serviços }\end{array}$ & $\begin{array}{l}\text { são os custos incorridos no processo de obtenção de bens e serviços } \\
\text { e outros objetos de custos e que correspondem ao somatório dos } \\
\text { elementos de custo, ligados à prestação daquele serviço. }\end{array}$ \\
\hline Custos reais & são os custos históricos apurados a posteriori e que foram incorridos. \\
\hline Custo direto & é todo o custo que é identificado ou associado ao objeto do custo. \\
\hline Custo indireto & $\begin{array}{l}\text { é o custo que não pode ser identificado diretamente ao objeto do } \\
\text { custo, devendo sua apropriação ocorrer por meio da utilização de } \\
\text { bases de rateio ou direcionadores de custos. }\end{array}$ \\
\hline Custo fixo & $\begin{array}{l}\text { é o que não é influenciado pelas atividades desenvolvidas, mantendo } \\
\text { seu valor constante em intervalo relevante das atividades } \\
\text { desenvolvidas pela entidade. }\end{array}$ \\
\hline Custo variável & $\begin{array}{l}\text { é o que tem valor total diretamente proporcional à quantidade } \\
\text { produzida/ofertada. }\end{array}$ \\
\hline Custo operacional & $\begin{array}{l}\text { é o que ocorre durante o ciclo de produção dos bens e serviços e } \\
\text { outros objetos de custos, como energia elétrica, salários, etc. }\end{array}$ \\
\hline Custo predeterminado & $\begin{array}{l}\text { é o custo teórico, definido a priori para valorização interna de } \\
\text { materiais, produtos e serviços prestados. }\end{array}$ \\
\hline Custo padrão (standard) & é o custo ideal de produção de determinado produto/serviço. \\
\hline Custo estimado & $\begin{array}{l}\text { é o custo projetado para subsidiar o processo de elaboração dos } \\
\text { orçamentos da entidade para determinado período; pode basear-se } \\
\text { em simples estimativa ou utilizar a ferramenta do custo padrão. }\end{array}$ \\
\hline Custo controlável & $\begin{array}{l}\text { utiliza centro de responsabilidade e atribui ao gestor apenas os custos } \\
\text { que ele pode controlar. }\end{array}$ \\
\hline Hora ocupada & $\begin{array}{l}\text { é o tempo despendido pela força do trabalho nos departamentos de } \\
\text { serviço destinados a atender às tarefas vinculadas com as áreas de } \\
\text { produção de bens ou serviços. }\end{array}$ \\
\hline Hora máquina & $\begin{array}{l}\text { corresponde à quantidade de horas que as máquinas devem funcionar } \\
\text { para realizar a produção de bens e serviços e outros objetos de custos } \\
\text { do período. É aplicada às unidades de produto ou serviço em função } \\
\text { do tempo de sua elaboração. }\end{array}$ \\
\hline
\end{tabular}




\begin{tabular}{|l|l|}
\hline Mão de obra direta & $\begin{array}{l}\text { corresponde ao valor da mão de obra utilizado para a produção de } \\
\text { bens e serviços e outros objetos de custos. }\end{array}$ \\
\hline Sobre aplicação & $\begin{array}{l}\text { é a variação positiva apurada entre os custos e metas estimados e os } \\
\text { executados. }\end{array}$ \\
\hline Sub aplicação & $\begin{array}{l}\text { é a variação negativa apurada entre os custos e metas estimados e os } \\
\text { executados. }\end{array}$ \\
\hline Custo de oportunidade & $\begin{array}{l}\text { é o custo objetivamente mensurável da melhor alternativa desprezada } \\
\text { relacionado à escolha adotada. }\end{array}$ \\
\hline Receita econômica & $\begin{array}{l}\text { é o valor apurado a partir de benefícios gerados à sociedade pela ação } \\
\text { pública, obtido por meio da multiplicação da quantidade de serviços } \\
\text { prestados, bens ou produtos fornecidos, pelo custo de oportunidade, } \\
\text { custo estimado, custo padrão, etc. }\end{array}$ \\
\hline
\end{tabular}

Fonte: Elaboração própria baseada na NBC T 16.11 (CONSELHO FEDERAL DE CONTABILIDADE, 2012).

A definição de custo da NBCT 16.11 (CONSELHO FEDERAL DE CONTABILIDADE, 2012) ratifica o conceito trazido anteriormente por Martins (2003, p. 17): "gasto relativo a bem ou serviço utilizado na produção de outros bens ou de prestação de serviços".

Nas indústrias os custos seriam os fatores utilizados diretamente na produção, entretanto, no governo, os custos seriam caracterizados pelas medidas monetárias dos sacrifícios financeiros com os quais têm de arcar a fim de atingir seus objetivos, quem podem ser a utilização de um produto ou serviço qualquer, utilizados na obtenção de outros bens ou serviços.

Para esclarecer melhor a definição acima, Machado e Holanda (2010) demonstram através da figura 3 o relacionamento entre os conceitos da contabilidade governamental e de custos.

FIGURA 3 - Correspondência dos conceitos entre a contabilidade governamental e de custos.

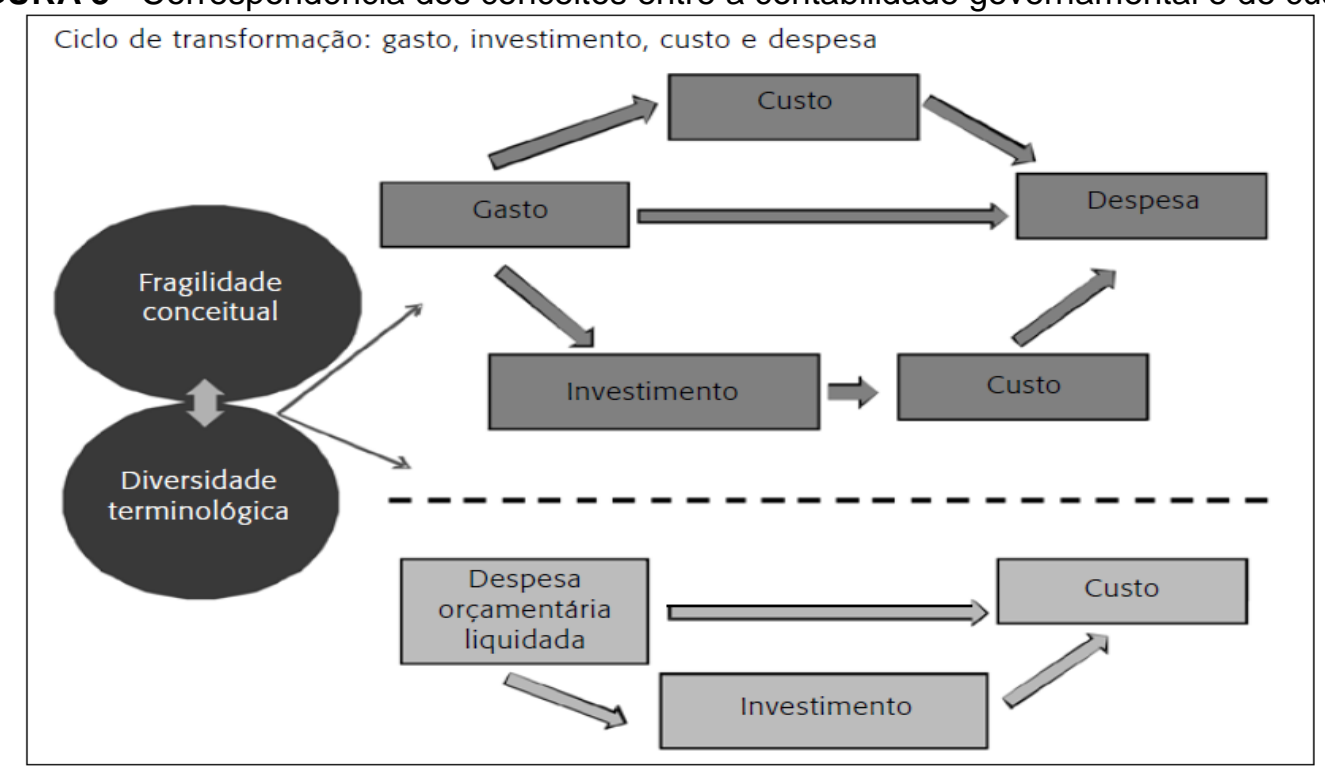

Fonte: Machado e Holanda (2010, p. 801). 
Os autores destacam o fato de que ainda existem dificuldades na aplicação desses conceitos no processo de análise dos gastos no setor público. Costa Junior (2016) explica que na contabilidade privada a distinção entre custo e despesa é bem mais descomplicada do que no setor público, pois no setor privado, a contabilidade de custo separa esses conceitos da seguinte forma: os gastos aplicados na produção até que o produto seja disponibilizado para venda é considerado custo.

No setor público as despesas orçamentárias têm um ciclo próprio, composto por quatro fases: fixação, empenho, liquidação e pagamento. A grande quantidade de fases da despesa no setor público em relação ao privado acaba por dificultar a análise de que em que ponto existirá a separação entre custos e despesas (COSTA JÚNIOR, 2016).

Quadro 6 - Contabilidade Governamental x contabilidade de custos: correspondência terminológica.

\begin{tabular}{|l|l|}
\hline \multicolumn{1}{|c|}{ Contabilidade Governamental } & \multicolumn{1}{c|}{ Contabilidade de Custos } \\
\hline Fixação & Padrão \\
\hline Empenho & Não é tradicionalmente usado \\
\hline Liquidação & Gasto (realizado) \\
\hline Pagamento & Desembolso \\
\hline
\end{tabular}

Fonte: Adaptado de Machado (2002, p. 120)

O quadro 6 demonstra que as fases de empenho e liquidação não são tradicionalmente utilizadas no setor privado, pois elas foram determinadas inicialmente pela Lei $n^{\circ}$ 4320/1964 (BRASIL, 1964) como obrigatórias para a União, Estados, Municípios e o Distrito Federal.

Pacelli (2018) destaca que o SICSP é apoiado em três elementos: Sistema de acumulação, Sistema de custeio e Método de custeio. A NBC T 16.11 (CONSELHO FEDERAL DE CONTABILIDADE, 2012, p. 4) conceitua esses três elementos da seguinte maneira:

1. Sistema de acumulação corresponde à forma como os custos são acumulados e apropriados aos bens e serviços e outros objetos de custos e está relacionado ao fluxo físico e real da produção. Elas podem ocorrer no setor público de duas maneiras, por ordem de serviço ou produção e de forma contínua. 
a) Por ordem de serviço ou produção é o sistema de acumulação que compreende especificações predeterminadas do serviço ou produto demandado, com tempo de duração limitado. Adequa-se melhor para tratamento dos custos de investimentos e de projetos específicos, por exemplo, as obras e benfeitorias.

b) De forma contínua é o sistema de acumulação que compreende demandas de caráter continuado e são acumuladas ao longo do tempo.

2. Sistema de Custeio refere-se ao modelo de mensuração e assim podem ser custeados os diversos agentes de acumulação de acordo com diferentes unidades de medida, ficando dependente das necessidades daqueles que tomam decisões. Podem utilizar as seguintes unidades de medida: custo histórico; custo-corrente; custo estimado; e custo padrão.

a) Custo Histórico baseia-se no valor original de aquisição e entrada, ou seja, histórico (Martins, 2003) ${ }^{1}$.

b) Custo-Corrente (padrão corrente) refere-se à meta fixada por um período para um determinado produto ou serviço, baseado em estudos teóricos e em pesquisas e testes práticos, buscando máxima proximidade à realidade (MARTINS, 2003) ${ }^{2}$.

c) Custo estimado é o custo projetado para subsidiar o processo de elaboração dos orçamentos da entidade para determinado período; pode basear-se em simples estimativa ou utilizar a ferramenta do custo padrão (NBCT 16.11).

d) Custo padrão (standard) é o que resulta da consideração de normas técnicas atribuídas aos vários fatores de produção, como consumo de matérias, mão de obra, máquinas, etc., para a definição do custo do produto ou do serviço (NBC T 16.11).

3. Método de custeio se refere ao "método de apropriação de custos e está associado ao processo de identificação e associação do custo ao objeto que está sendo custeado". O método deve ser escolhido conforme a disponibilidade de informações e no volume de recursos necessários para obtenção das informações ou dados. Dependendo da característica do objeto de custeio as entidades podem adotar mais de uma metodologia de

\footnotetext{
${ }^{1}$ A NBC T menciona custo histórico como uma unidade de medida do Sistema de Custeio, porém não a define, por esse motivo adotou-se a conceituação trazida pelo Professor Eliseu Martins.

${ }^{2}$ A NBC T menciona custo corrente como uma unidade de medida do Sistema de Custeio, porém não a define, por esse motivo adotou-se a conceituação trazida pelo Professor Eliseu Martins.
} 
custeamento. No item 9 são listados os principais métodos de custeio: direto, variável, por absorção, por atividade e pleno $^{3}$.

a) Custeio direto é o custeio que aloca todos os custos - fixos e variáveis - diretamente a todos os objetos de custo sem qualquer tipo de rateio ou apropriação.

b) Custeio variável que apropria aos produtos ou serviços apenas os custos variáveis e considera os custos fixos como despesas do período.

c) Custeio por absorção que consiste na apropriação de todos os custos de produção aos produtos e serviços.

d) Custeio pleno que consiste na apropriação dos custos de produção e das despesas aos produtos e serviços.

e) Custeio por atividade que considera que todas as atividades desenvolvidas pelas entidades são geradoras de custos e consomem recursos. Procura estabelecer a relação entre atividades e os objetos de custo por meio de direcionadores de custos que determinam quanto de cada atividade é consumida por eles.

Torna-se imperioso também demonstrar os atributos da informação de custos, conforme a NBC T 16.11 (CONSELHO FEDERAL DE CONTABILIDADE, 2012), pois são requisitos essenciais para que os dados extraídos do sistema de informação sejam confiáveis e atendam às finalidades as quais se destinam.

No quadro 7 são trazidos os conceitos dos atributos da informação de custos que são: relevância, utilidade, oportunidade, valor social, fidedignidade, especificidade, comparabilidade, adaptabilidade e granularidade.

\footnotetext{
${ }^{3}$ Os grandes autores da Contabilidade de Custos como os Professores Eliseu Martins, Silvério das Neves, Paulo Viceconti e Giovani Pacelli, em suas obras consideram Custeio Variável e Direto como um único método de custeio, caracterizado pelo fato de não considerar os custos fixos como custo de produção e sim como despesa, indo diretamente para o Resultado do Exercício. A distinção realizada nesta dissertação foi baseada nas definições dadas pela NBCT 16.11, por ser o principal balizador do estudo de custo do setor público no Brasil. Entretanto, não se podem desconsiderar as classificações dantes estabelecidas e de importância reconhecida pelos profissionais da contabilidade do país, que contribuíram, inclusive, para a formação conceitual da contabilidade de custos aplicada ao setor público.
} 
Quadro 7: Atributos da informação de custos

\begin{tabular}{|c|l|}
\hline Relevância & $\begin{array}{l}\text { Entendida como a qualidade que a informação tem de influenciar as } \\
\text { decisões de seus usuários auxiliando na avaliação de eventos } \\
\text { passados, presentes e futuros }\end{array}$ \\
\hline Utilidade & $\begin{array}{l}\text { Qeve ser útil à gestão tendo a sua relação custo benefício positiva } \\
\text { Oportidade de a informação estar disponível no momento adequado à } \\
\text { tomada de decisão }\end{array}$ \\
\hline Valor social & $\begin{array}{l}\text { Deve proporcionar maior transparência e evidenciação do uso dos } \\
\text { recursos públicos }\end{array}$ \\
\hline Fidedignidade & $\begin{array}{l}\text { Referente à qualidade que a informação tem de estar livre de erros } \\
\text { materiais e de juízos prévios, devendo, para esse efeito, apresentar as } \\
\text { operações e acontecimentos de acordo com sua substância e realidade } \\
\text { econômica e, não, meramente com a sua forma legal }\end{array}$ \\
\hline Especificidade & $\begin{array}{l}\text { Informações de custos devem ser elaboradas de acordo com a } \\
\text { finalidade específica pretendida pelos usuários }\end{array}$ \\
\hline Comparabilidade & $\begin{array}{l}\text { Entende-se a qualidade que a informação deve ter de registrar as } \\
\text { operações e acontecimentos de forma consistente e uniforme, a fim de } \\
\text { conseguir comparabilidade entre as distintas instituições com } \\
\text { características similares. É fundamental que o custo seja mensurado } \\
\text { pelo mesmo critério no tempo e, quando for mudada, esta informação } \\
\text { deve constar em nota explicativa }\end{array}$ \\
\hline Adaptabilidade & $\begin{array}{l}\text { Deve permitir o detalhamento das informações em razão das diferentes } \\
\text { expectativas e necessidades informacionais das diversas unidades } \\
\text { organizacionais e seus respectivos usuários. }\end{array}$ \\
\hline Granularidade & $\begin{array}{l}\text { Que o sistema deva ser capaz de produzir informaçães em diferentes } \\
\text { níveis de detalhamento, mediante a geração de diferentes relatórios, } \\
\text { sem perder o atributo da comparabilidade. }\end{array}$ \\
\hline
\end{tabular}

Fonte: Adaptado da NBC T 16.11 (CONSELHO FEDERAL DE CONTABILIDADE, 2012)

A Norma orienta, também, que os objetos de custos que foram definidos pela entidade de maneira antecipada, devem ser evidenciados ou apresentados em notas explicativas, onde será demonstrado o montante de custos dos principais objetos, quais os critérios de comparabilidade utilizados e qual o método de custeio adotado para apurar os custos. Apresentar essas informações faz parte do procedimento de Evidenciação das informações de custos, sendo, portanto, uma iniciativa de transparência perante os usuários dessas informações.

Quanto à implantação do SICSP, o item 21 da NBC T 16.11 (CONSELHO FEDERAL DE CONTABILIDADE, 2012) recomenda que ocorra de forma sistemática e gradual levando em consideração os objetivos organizacionais pretendidos, os processos decisórios que usarão as informações de custos conforme os grupos de usuários, e os critérios de transparência e controle social.

Além dessas orientações a Norma torna obrigatória a adoção dos princípios de contabilidade, principalmente no relativo à adoção do regime de competência, recomendando ajustes naqueles registros que forem realizados de forma diferente. Essa adoção foi realizada de maneira gradativa até que fosse alcançado o patamar atual. 
2.2.2 O regime de Competência para geração de informações de custos

Ao tratar sobre a implantação de sistema de custos no governo federal, Machado e Holanda (2010, p. 799) relataram que "a geração de informações de custos pressupõe a adoção do regime de competência”. E que, enquanto a contabilidade governamental não adotasse em sua plenitude o regime de competência seria necessário realizar alguns ajustes contábeis para gerar informações adequadas para análise.

Pacelli (2018) faz a diferenciação do regime de competência para o regime de caixa e destaca que são os regimes utilizados sob o enfoque patrimonial. No regime de caixa, a receita da entidade é reconhecida quando o recurso financeiro entra no caixa, e a despesa é reconhecida quando o recurso financeiro sai do caixa. Pelo regime de competência, a receita é reconhecida quando ocorre variação patrimonial aumentativa e a despesa da entidade é reconhecida quando ocorrer variação patrimonial diminutiva.

Pigatto et al (2010; p. 826) cita que no regime de competência "transações e outros eventos são reconhecidos quando ocorrem e não somente quando o caixa ou seus equivalentes são recebidos ou pagos". Portanto, as transações e eventos são registrados contabilmente e reconhecidos nas demonstrações contábeis obedecendo aos seus respectivos períodos de ocorrência.

De acordo com Gnisci (2010) o regime de competência mostrou-se mais eficaz nos países em que foi adotado, pois permite o registro, controle e disponibilização de informações de todas as transações que alteram o ativo e 0 passivo da instituição, e não somente de receitas e despesas como ocorre no regime de caixa. No regime de competência a contabilidade deve se preocupar com a capitalização e depreciação de todos os ativos e não apenas com o aspecto orçamentário. Assim, ele facilita a demonstração e evidenciação das aplicações e investimentos da gestão pública no decorrer de vários períodos, sendo considerado o regime que atende de maneira mais eficaz a disponibilização de informações de base gerencial.

O texto da Lei $n^{\circ} 4.320 / 1964$ (BRASIL, 1964) trata apenas dos custos dos serviços industriais, entretanto, Machado e Holanda (2010) comentam que nos últimos anos o estudo dos custos do setor público tem avançado significativamente, 
impulsionado pela reformulação dos sistemas contábeis brasileiros para adaptação aos sistemas de contabilidade internacional.

Tal adaptação dos sistemas contábeis para incorporação do Regime de Competência traz consigo mudanças significativas nos sistemas contábeis, financeiros, orçamentários e patrimoniais, pois envolve questões políticas que refletirão reformas de cunho institucional saneando necessidades permanentes do Estado Brasileiro. Por esses motivos, tal processo de reconfiguração tem sido tratado como uma questão de Estado e não meramente técnico (GNISCI, 2010).

No Brasil, a Nova Norma Brasileira de Contabilidade NBC TSP, de 23 de setembro de 2016 (CONSELHO FEDERAL DE CONTABILIDADE, 2016), que estabeleceu a Estrutura Conceitual para Elaboração e Divulgação de Informação Contábil de Propósito Geral pelas Entidades do Setor Público, definiu que o regime de competência deve basear a elaboração e a divulgação dos Relatórios Contábeis de Propósito Geral das Entidades do Setor Público, os denominados RCPGs. A Estrutura Conceitual também menciona que a estrutura das demonstrações contábeis está voltada para a informação contábil baseada no regime de competência (CONSELHO FEDERAL DE CONTABILIDADE, 2016).

O Guia Rápido do SIC (BRASIL. Secretaria do Tesouro Nacional, 2017b, p. 9) corrobora nesse sentido, afirmando que "para que as informações de custos sejam geradas de maneira correta, é obrigatória sua apuração com base no regime de competência, podendo ser mensurada por meio de ajustes nas informações orçamentárias". Inicialmente, a informação de custo surgirá a partir de ajustes efetuados na informação inicial obtida do SIAFI, pois, o estágio da despesa orçamentária que mais se aproxima da informação de custo é o da liquidação. Para facilitar esse entendimento dos estágios das despesas sob a abordagem orçamentária é necessário mencionar sua definição sob a égide da Lei $n^{\circ} 4.320 / 64$ (BRASIL, 1964) no seu art. 35 que estabelece: "Pertencem ao exercício financeiro: I - as receitas nele arrecadadas; II - as despesas nele legalmente empenhadas".

A despesa orçamentária possui três estágios: empenho, liquidação e pagamento. $\mathrm{O}$ empenho é $\mathrm{o}$ ato emanado de autoridade competente que cria para $\mathrm{o}$ Estado obrigação de pagamento pendente ou não de implemento de condição, conforme descrito no Art. 58 da supracitada Lei. Consistindo, portanto, na reserva de dotação orçamentária para um fim específico. 
O estágio de liquidação é a verificação do direito adquirido pelo credor tendo por base os títulos e documentos comprobatórios do respectivo crédito. Essa verificação tem por fim apurar a origem, o objeto, a importância exata e a quem se deve pagar tal importância para extinguir a obrigação, conforme estabelecido no Art. 63, § 1ํ, I, II e III, da Lei no 4.320/1964 (BRASIL, 1964).

Esta etapa representa o momento em que a despesa empenhada está pronta para pagamento e, de acordo com o Modelo Conceitual de custos aplicado ao setor público é o estágio da despesa que mais se aproxima da informação de custo, ou seja, o fato gerador da despesa, sendo esse o ponto de partida da informação que deve alimentar o sistema de custos (BRASIL. Secretaria do Tesouro Nacional, 2018b).

O último estágio da despesa é o pagamento, a entrega de numerário ao credor por meio de emissão de ordem bancária, cheque nominativo, ordens de pagamentos ou crédito em conta, e só pode ser efetuado após a regular liquidação da despesa, nos termos dos artigos 64 e 65 da Lei n 4320/64 (BRASIL, 1964).

Após esse entendimento, ao verificar que o termo "liquidação" na contabilidade pública corresponde ao conceito de "gasto" na contabilidade de custos, pode-se utilizar a despesa orçamentária liquidada como fato gerador para a construção do Sistema de Informações de Custos. As despesas orçamentárias liquidadas serão custos quando relativas a bens ou a serviços para utilização imediata. Quando a execução representar a aquisição elementos que serão ativados (estoques, imobilizado etc.), o momento do custo ocorrerá a posteriori (BRASIL. Secretaria do Tesouro Nacional, 2017b).

O Guia Rápido do SIC (BRASIL. Secretaria do Tesouro Nacional, 2017b) destaca que fenômenos puramente econômicos, como a depreciação, não são objetos do Orçamento. Assim, esses registros devem ser adicionados aos valores orçamentários para que se possa gerar informações de custos que atendam ao regime de competência.

De maneira diferente, nas aquisições de veículo por órgão público, por exemplo, tem-se uma despesa de capital apresentada na execução orçamentária, mas não se reconhece esse gasto como custo nesse momento, pois se classifica como um investimento. Nesse caso, o custo será reconhecido ao longo do período em que o veículo gerar benefícios para o órgão, através das cotas de depreciação do bem (BRASIL. Secretaria do Tesouro Nacional, 2017b). 
Situação semelhante ocorre dentro da despesa executada quando se encontram valores das aquisições de materiais de consumo que serão estocados, pois só devem ser considerados como custo no momento de seu consumo. Assim, no momento da aquisição são excluídos da apuração de custos e, quando há requisição para consumo são adicionados para compor o custo do período (BRASIL. Secretaria do Tesouro Nacional, 2017b)

Figura 4: Ajustes patrimoniais para geração de informação de custos

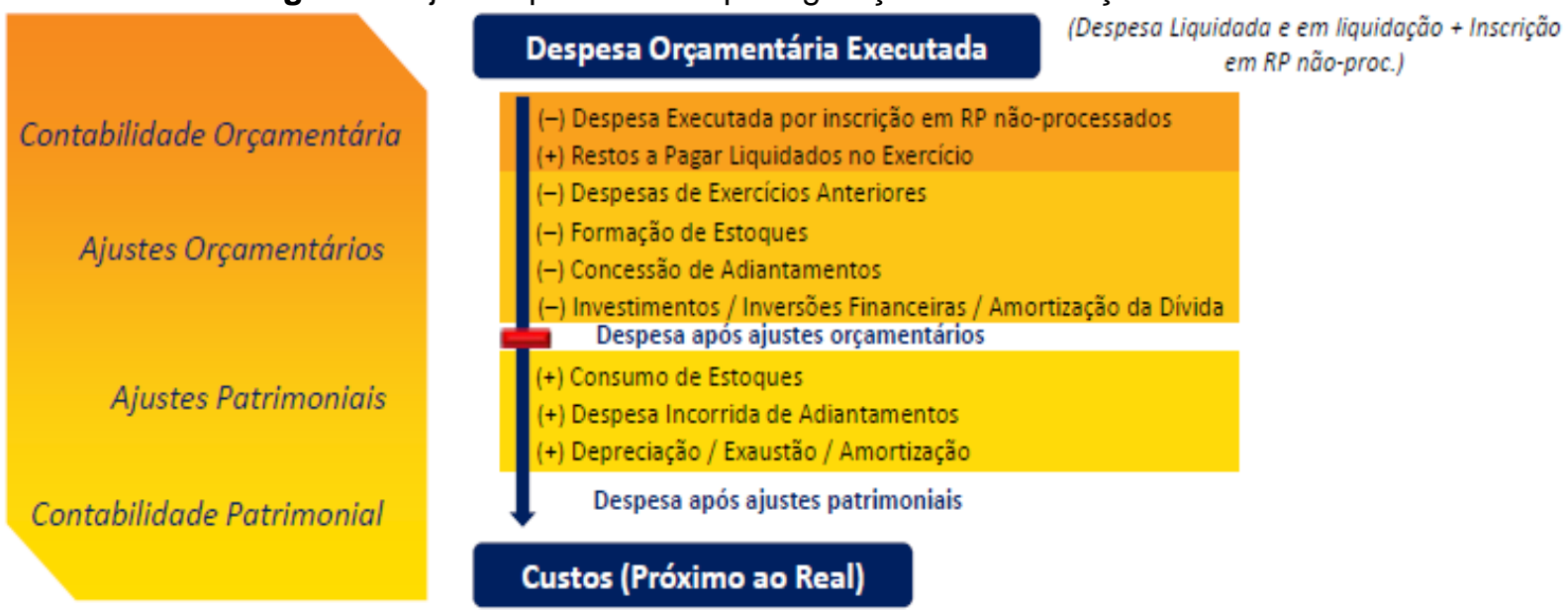

Fonte: Brasil. Secretaria do Tesouro Nacional (2017d, p.39).

Conforme descrito na figura 4 são realizados os ajustes contábeis em duas etapas. Primeiramente, se identificam as informações baseadas em contas contábeis que trazem a informação orçamentária e não orçamentária, ajustando-se por acréscimo ou exclusão os valores, conforme conceitos específicos da contabilidade de custos. E posteriormente, são excluídas as informações que estejam nas contas contábeis, mas que não compõem a informação de custo (BRASIL. Secretaria do Tesouro Nacional, 2017a).

Os ajustes patrimoniais demonstrados são necessários para gerar informações de custos fidedignas e mais próximas da realidade, baseada no regime contábil da competência.

Essa sistemática passou a ser utilizada para gerar dados relevantes através do Sistema de Informação de Custos do Governo Federal - SIC a partir da homologação da primeira versão em março de 2010. 


\subsection{Sistema de Informações de Custos do Governo Federal - SIC}

De acordo com a definição do Guia Rápido do SIC (BRASIL. Secretaria do Tesouro Nacional, 2017b, p. 1), o SIC é uma ferramenta tecnológica baseada em um modelo conceitual e sistêmico que consegue integrar os dados dos principais sistemas estruturantes do Governo Federal (Figura 5) em uma única base de dados, e organiza todas as informações de cunho físico e financeiro oriundas desses sistemas.

Para que se pudesse alcançar a primeira versão do SIC foram necessários esforços de diversos atores: ministérios e entidades governamentais, a comunidade acadêmica nacional e internacional, órgãos de controle externo e etc., todos sendo articulados através da Secretaria Executiva do Ministério da Fazenda.

Inicialmente, foram relevantes os trabalhos da Comissão Interministerial por volta do ano de 2005, cuja missão era subsidiar a implantação do SIC através da proposição de diretrizes, métodos e procedimentos e elaboração de estudos no tema. Essa Comissão foi a primeira iniciativa após o Acórdão n 1078/2004 do TCU (BRASIL. Tribunal de Contas da União, 2004) que determinou providências por parte da administração pública federal com a maior brevidade possível para dispor de um sistema de custo, considerando a Lei de Responsabilidade Fiscal (BRASIL, 2000) e as determinações da Lei de Diretrizes Orçamentárias de 2004 (MONTEIRO et al. 2010).

Conforme Monteiro et al. (2010), em 2008 foi instituída a Câmara Técnica de Qualidade do Gasto, no âmbito do Comitê Técnico de Orçamento conduzido pela Secretaria de Orçamento Federal, do Ministério do Planejamento, Orçamento e Gestão (MPOG), para que fosse dada continuidade aos trabalhos da Comissão Interministerial. No ano seguinte, foi criado o grupo técnico na Secretaria do Tesouro Nacional do Ministério da Fazenda para produzir a versão inicial do SIC juntamente com o Serviço de Processamento de Dados do Governo Federal - SERPRO e a colaboração do MPOG.

Os passos seguintes foram: buscar a participação e cooperação dos órgãos gestores dos sistemas que dariam suporte de dados ao SIC, realizar visitas técnicas para conhecer sistemas de custos de outros órgãos como o Instituto Nacional de Metrologia, Qualidade e Tecnologia - INMETRO e o Banco Central do Brasil - Bacen 
e introduzir o universo do SIC no meio acadêmico e órgãos federais através de seminários "técnicos conceituais" (MONTEIRO et al. 2010. p. 6).

O professor Dr. Victor Branco de Holanda, um dos idealizadores e multiplicador do SIC através dos Seminários de Custos no Setor Público, mencionou que quando a informação de custos na administração pública estiver sendo utilizada de fato como base para fins de elaborar melhores planos, projetos, escolher entre alternativas mais econômicas e realizar comparações visando resultados a baixos custos, então se produzirá uma "verdadeira revolução no setor público brasileiro" (HOLANDA; LATTMAN-WELTMAN; GUIMARÃES, 2010, p. 118). Em um dos seminários o professor supramencionado ilustrou, através da figura 5 , que essa revolução perpassa por uma mudança cultural e que a implementação do SIC servirá de contribuição para uma gestão mais racional do Orçamento Federal.

Figura 5: Mudança cultural na gestão através do SIC

\section{Sistema de Informação de Custos do Governo Federal}

\section{Mudança cultural}

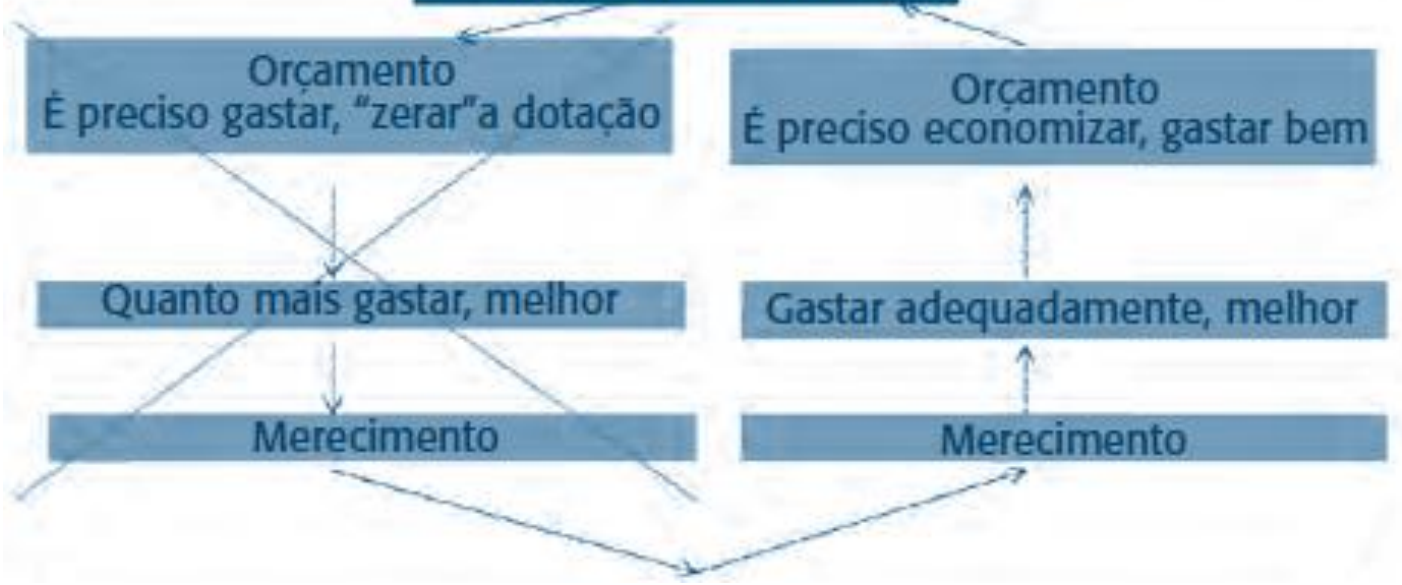

Fonte: Holanda; Lattman-Weltman; Guimarães (2010, p. 118).

Para tanto, os eventos de treinamento de multiplicadores e capacitação dos usuários foram iniciados após a etapa de homologação do sistema em 2010. No ano de 2011 foi publicada a Portaria STN n¹57 (BRASIL. Secretaria do Tesouro Nacional, 2011a) que dispunha sobre a criação do SIC e veio normatizar as atribuições e abrangências do sistema. No mesmo ano, a Portaria STN $\mathrm{n}^{\circ} 716$ (BRASIL. Secretaria do Tesouro Nacional, 2011b) veio dispor sobre as competências dos Órgãos Central e Setorial do Sistema de Custos do Governo 
Federal. Por fim, foi publicada em 30 de dezembro de 2011 a Portaria STN n 864 (BRASIL. Secretaria do Tesouro Nacional, 2011c), que criou o Macroprocesso do Sistema de Custos do Governo Federal - MPCUST que direciona as atividades inerentes aos Órgãos Setoriais.

Pacelli (2018) destaca que a STN fez uma importante distinção entre "Sistema de Custos do Governo Federal" e "Sistema de Informações de Custos" para que não houvesse distorção de entendimentos sobre os conceitos, conforme o quadro 8.

Quadro 8 - Sistema de Custos do Governo Federal versus Sistema de Informações de Custos.

\begin{tabular}{|c|l|}
\hline $\begin{array}{c}\text { Sistema de Custos do } \\
\text { Governo Federal }\end{array}$ & $\begin{array}{l}\text { Sistema Estruturante do Governo Federal que é composto pela } \\
\text { Secretaria do Tesouro Nacional como órgão central e os órgãos } \\
\text { setoriais. }\end{array}$ \\
\hline $\begin{array}{c}\text { Sistema de } \\
\text { Informações de Custos } \\
\text { - SIC }\end{array}$ & $\begin{array}{l}\text { Sistema Informacional do Governo Federal que tem por objetivo o } \\
\text { acompanhamento, a avaliação e a gestão de custos dos programas e } \\
\text { das unidades da Administração Pública Federal e o apoio aos gestores } \\
\text { no processo decisório. }\end{array}$ \\
\hline
\end{tabular}

Fonte: Adaptado de Pacelli (2018, p. 1282)

A Portaria STN n¹57 (BRASIL. Secretaria do Tesouro Nacional, 2011a) definiu a estrutura do Sistema de Custos do Governo Federal, na qual a Secretaria do Tesouro Nacional do Ministério da Fazenda figura como Órgão Central, e os Órgãos Setoriais são as unidades de gestão interna dos Ministérios do Poder Executivo e da Advocacia-Geral da União, que são os responsáveis pelo acompanhamento de custos no SIC. As unidades de gestão interna dos Poderes Legislativo e Judiciário e o Ministério Público da União poderão integrar o Sistema de Custos do Governo Federal caracterizados também como Órgãos Setoriais.

\subsubsection{Funcionamento e objetivos do SIC}

De acordo com Monteiro et al. (2010, p.2) o SIC vem "fornecer informações para subsidiar decisões governamentais de alocação mais eficiente do gasto público". O sistema utiliza os principais sistemas estruturantes de governo como fonte dos dados para a geração de informações, principalmente os capturados pelos sistemas de informação contábeis e financeiros. 
Figura 6: Sistemas Estruturantes do Governo Federal - Visão Sistêmica

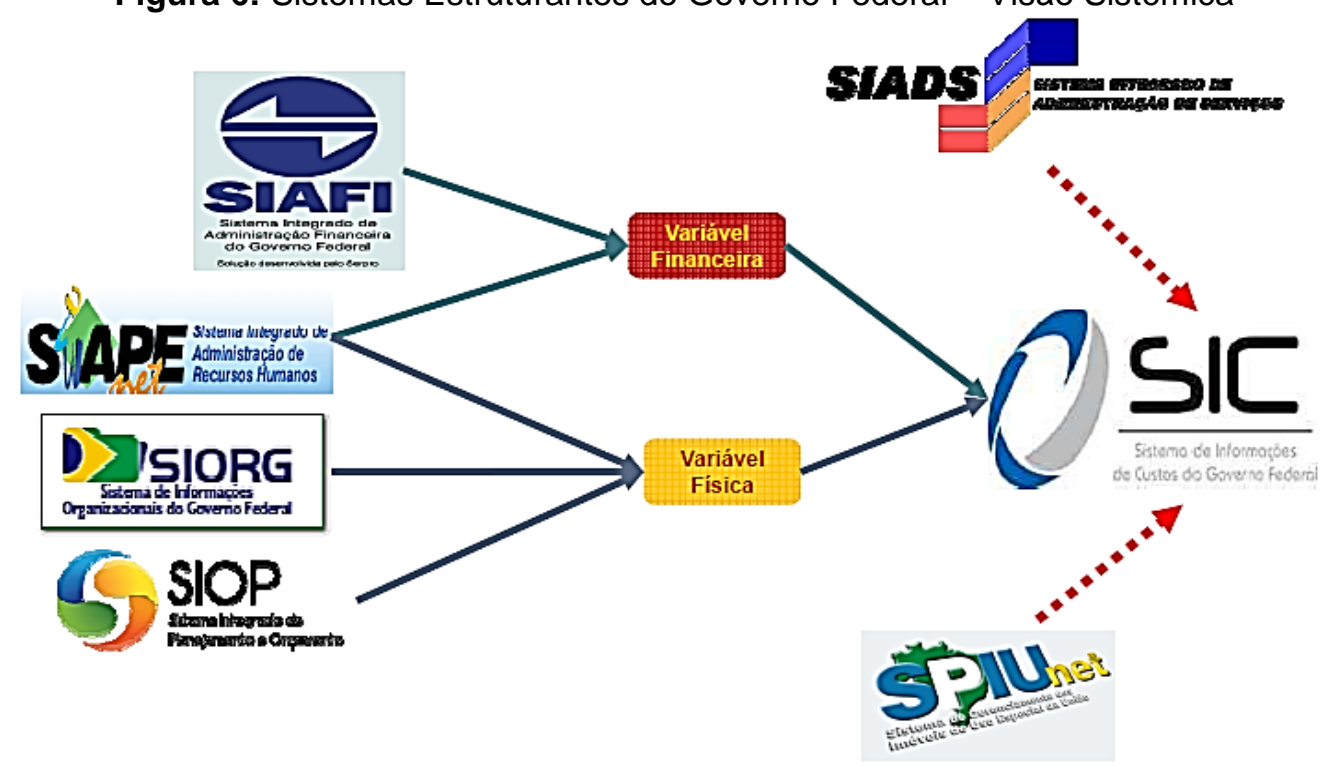

Fonte: Brasil. Secretaria do Tesouro Nacional (2017d, p. 48)

Os principais sistemas estruturantes do Governo Federais mencionados SIORG, SIAPE, SIAFI, SIOP, SIADS e SPIUNET, conforme figura 6, têm suas informações consolidadas em uma única base de dados através do SIC. Após o tratamento contábil dos dados são fornecidos os relatórios de interesse dos usuários. Demonstra-se no quadro 9 as funções dos sistemas estruturantes dentro do sistema público federal que auxiliam no suporte de dados ao SIC.

Quadro 9: Principais Sistemas Estruturantes do Governo Federal

\begin{tabular}{|c|l|l|c|}
\hline SIAFI & $\begin{array}{l}\text { Sistema Integrado } \\
\text { de Administração } \\
\text { Financeira }\end{array}$ & $\begin{array}{l}\text { Principal instrumento utilizado para registro, acompanhamento e } \\
\text { controle da execução orçamentária, financeira e patrimonial do } \\
\text { Governo Federal. }\end{array}$ \\
\hline SIORG & $\begin{array}{l}\text { Sistema de } \\
\text { Organização e } \\
\text { Inovação } \\
\text { Institucional }\end{array}$ & $\begin{array}{l}\text { Fonte oficial de informações sobre a estrutura organizacional } \\
\text { dos órgãos e entidades do Governo Executivo Federal - } \\
\text { Administração Direta, Autarquias e Fundações }\end{array}$ \\
\hline SIAPE & $\begin{array}{l}\text { Sistema Integrado } \\
\text { de Administração } \\
\text { de Recursos } \\
\text { Humanos }\end{array}$ & $\begin{array}{l}\text { Integra todas as plataformas de gestão da folha de pessoal dos } \\
\text { servidores públicos. É responsável pela produção das folhas de } \\
\text { pagamento dos mais de 200 órgãos federais. }\end{array}$ \\
\hline SPIUNET & $\begin{array}{l}\text { Sistema Integrado } \\
\text { de Planejamento e } \\
\text { Orçamento }\end{array}$ & $\begin{array}{l}\text { Sistema de Gestão } \\
\text { dos Imóveis de } \\
\text { Uso Especial da } \\
\text { União }\end{array}$ & $\begin{array}{l}\text { Faz a gerência da utilização dos imóveis da União denominados } \\
\text { "Bens de Uso Especial". Mantém cadastro de imóveis e } \\
\text { usuários, emite relatórios gerenciais e utiliza elementos gráficos } \\
\text { como mapas e fotos dos imóveis. }\end{array}$ \\
\hline SIADS & $\begin{array}{l}\text { Sistema Integrado que } \\
\text { de Administração } \\
\text { de Serviços }\end{array}$ & $\begin{array}{l}\text { Possibilita o controle de estoques de materiais, bens } \\
\text { patrimoniais e serviços de transporte. Permite o controle de } \\
\text { depreciação dos bens, viabiliza a realização de inventário } \\
\text { eletrônico e automação do registro contábil, ao registrar o ato e } \\
\text { fato das ações administrativas no SIAFI. }\end{array}$ \\
\hline
\end{tabular}

Fonte: Elaboração própria a partir de consulta aos sites dos sistemas estruturantes (2018). 
Dos sistemas estruturantes do Governo Federal, o SIOP, SIAPE e SIADS contribuem fornecendo ao SIC tanto as variáveis (ou dimensões) físicas quanto financeiras. O SPIUNET e SIORG dão suporte através das variáveis físicas e o SIAFI fornece as informações de cunho estritamente financeiro. Conforme informações obtidas na Secretaria do Tesouro Nacional (BRASIL. Secretaria do Tesouro Nacional, 2017d), atualmente, o SIC ainda não se utiliza dos dados dos sistemas SPIUNET e SIADS, pois ainda estão sendo realizados os ajustes para que brevemente o funcionamento seja pleno.

Conforme o Guia Rápido do SIC (BRASIL. Secretaria do Tesouro Nacional, 2017b, p. 5), a metodologia do sistema está baseada em um conceito chamado em inglês de data warehouse (DW), "um depósito de dados orientado por assunto, integrado, histórico, extraídos dos sistemas transacionais, otimizados para processamento de consulta, organizados em tabelas". Conforme visualizado na figura 6 possibilita a criação de uma visão única e centralizada de dados que estavam dispersos em vários bancos, o que permite acesso rápido e consistente.

Quanto aos objetivos, o SIC foi idealizado para gerar informações de custos fidedignas que possam auxiliar o gestor público nas tomadas de decisão, e também para controlar e avaliar o grau de eficiência, eficácia e da efetividade dos programas de governo executados e em execução. Busca-se inferir, mensurar, resumir e relatar dados internos relativos às entidades públicas (MACHADO, 2002).

Conforme Monteiro et al. (2010) o SIC possui um caráter gerencial, não sendo mais um sistema operacional de administração financeira e nem substituindo os atuais sistemas contábeis. Propiciará melhorias na qualidade do gasto público através da efetiva mensuração do desempenho governamental. Para isso pode ser utilizado tanto pelos órgãos executores das políticas públicas quanto pelos órgãos centrais de planejamento e controle.

O SIC tem a possibilidade de fornecer informações para subsidiar as decisões governamentais relacionadas à alocação mais eficiente do gasto público, realizando a avaliação da eficiência do uso dos recursos, a eficácia na obtenção das metas dos gestores e a efetividade das políticas públicas na resolução dos problemas apresentados pela sociedade (MACHADO, 2002).

O SIC deve permitir a comparação de custos em todos os poderes e órgãos considerando as peculiaridades intrínsecas a cada um em razão de suas 
necessidades e expectativas das unidades em termos gerenciais e operacionais (Machado, 2010).

Machado e Holanda (2010, p. 797) relacionam de forma mais ampla as principais finalidades do Sistema de Informações de Custos do Governo Federal:

- Ampliação da eficiência alocativa, de suma importância para subsidiar o processo de decisão sobre alocação dos recursos públicos às necessidades e objetivos da gestão. Auxilia na avaliação se determinados bens ou serviços produzidos pelo governo justificam os custos incorridos, ou se existem alternativas a custos menos elevados;

- Maior eficiência operacional para viabilizar o alcance de uma relação custo x benefício dentro dos parâmetros definidos pela gestão no que se refere à produção de bens e serviços pelo Estado. Facilita a identificação de ineficiências e oportunidades de redução de gastos. Propicia a avaliação do resultado e desempenho, bem como benchmarking e identificação de atividades de baixo valor agregado;

- Estabelecimento de preços públicos e taxas, visando promover equidade e justiça na cobrança de bens ou serviços disponibilizados pelo Estado. Conhecer o custo dos produtos é essencial para que se estabeleça o preço justo a ser cobrado e/ou se conheça o resultado financeiro obtido, se positivo ou não.

- Auxiliar no processo integrado de planejamento-orçamento;

- Produzir subsídios para a tomada de decisão sobre a manutenção da produção de determinado bem, serviço ou atividade, ou a entrega do mesmo a organizações externas;

- Otimização das informações de gestão de resultados e de desempenho; e

- Formação de melhores ferramentas de controle voltadas para resultados.

Quanto aos principais usuários do SIC, Machado e Holanda (2010) destacam que são:

- Secretaria do Tesouro Nacional (STN) - órgão responsável pelo desenvolvimento e implantação do SIC;

- Secretaria de Orçamento Federal (SOF/Ministério da Fazenda) - Órgão que coordena a alocação de recursos públicos federais no âmbito do sistema federal de planejamento e orçamento; 
- Secretarias-executivas (Secex) - Unidades responsáveis por auxiliar os ministros de Estado no processo de supervisão e coordenação estratégica dos órgãos e entidades vinculados a cada ministério;

- Subsecretarias de Planejamento, Orçamento e Administração (Spoas) órgãos setoriais responsáveis, a nível federal, pela operacionalização dos sistemas de planejamento, orçamento, finanças, contabilidade, pessoal civil, de administração dos recursos de informação e informática, arquivo, serviços gerais no âmbito de cada órgão/entidade;

- Ordenadores de despesas (OD) - autoridades responsáveis pela autorização de despesas no âmbito dos órgãos e entidades públicas federais;

- Tribunal de Contas da União (TCU) - Responsável pelo julgamento das contas dos administradores públicos e demais responsáveis por dinheiro, bens e valores públicos federais. Atua no exercício da fiscalização contábil, financeira, orçamentária, operacional e patrimonial da União e das entidades da administração direta e indireta. Verifica os critérios de legalidade, legitimidade e economicidade e a aplicação das subvenções e da renúncia de receitas;

- Sociedade - pesquisadores e analistas especializados e o cidadão que possua interesse pelo controle social dos gastos públicos.

Dentre os usuários apontados, se faz mister destacar que o TCU no seu papel de órgão fiscalizador e julgador passou a exigir dos órgãos sob sua jurisdição (sendo a UFRA um deles), a apresentação da sistemática de custos que utilizada, conforme detalhamento no tópico seguinte, reforçando a importância da implementação da gestão de custos e da utilização do SIC.

\subsection{Informações de Custos das Unidades Prestadoras de Contas ao TCU}

Dentre as competências do Tribunal de Contas da União, prevista constitucionalmente no art. 71, Inciso II, encontra-se: "julgar as contas dos administradores e demais responsáveis por dinheiro, bens e valores públicos" (BRASIL, 1988). Assim, as Unidades Prestadoras de Contas ao TCU - UPC, que estiverem sobre sua jurisdição, devem apresentar anualmente o Relatório de Gestão - RG dos responsáveis pelas Unidades da Administração Pública Federal, o que engloba, portanto, as Instituições Federais de Ensino Superior - IFES. 
O dever de prestar contas ao TCU está amparado pelo art. 70 da Constituição Federal do Brasil que determina quem está obrigado a prestar contas dos recursos públicos e quais aspectos serão fiscalizados, conforme segue:

\begin{abstract}
Art. 70. A fiscalização contábil, financeira, orçamentária, operacional e patrimonial da União e das entidades da administração direta e indireta, quanto à legalidade, legitimidade, economicidade, aplicação das subvenções e renúncia de receitas, será exercida pelo Congresso Nacional, mediante controle externo, e pelo sistema de controle interno de cada Poder.

Parágrafo único. Prestará contas qualquer pessoa física ou jurídica, pública ou privada, que utilize, arrecade, guarde, gerencie ou administre dinheiros, bens e valores públicos ou pelos quais a União responda, ou que, em nome desta, assuma obrigações de natureza pecuniária. (BRASIL, 1988, grifo nosso).
\end{abstract}

A Prestação de Contas da Administração Pública Federal ao Tribunal de Contas da União apresentada através dos Relatórios de Gestão é normatizada pela Resolução TCU n²34/2010 (BRASIL. Tribunal de Contas da União, 2010a), Resolução TCU n² 244/2011 (BRASIL. Tribunal de Contas da União, 2011), IN TCU $n^{\circ}$ 63/2010 (BRASIL. Tribunal de Contas da União, 2010b), e IN TCU n 72/2013 (BRASIL. Tribunal de Contas da União, 2013), assim como as Decisões Normativas publicadas em cada exercício, ditando exigências específicas para a elaboração do Relatório de Gestão daquele ano.

Conforme o artigo da CF supracitado, os Relatórios de Gestão devem demonstrar os aspectos contábil, financeiro, orçamentário e patrimonial da União e da Administração Direta e Indireta.

Considerando a obrigatoriedade constitucional, a Secretaria do Tesouro Nacional emitiu a Portaria STN n 157, de 09 de março de 2011 (BRASIL. Secretaria do Tesouro Nacional, 2011a), que instituiu o Sistema de Custos do Governo Federal definindo os responsáveis pelo acompanhamento de custos no Sistema de informações de Custos - SIC. Também emitiu a Portaria STN n 716, de 24 de Outubro de 2011 (BRASIL. Secretaria do Tesouro Nacional, 2011b), que constitui o SIC como sistema informacional do Governo Federal para acompanhamento, avaliação e a gestão dos custos dos programas e das unidades da Administração Pública Federal e o apoio aos gestores no processo decisório.

O SIC foi disponibilizado pelo governo como uma opção de instrumento gerencial para auxílio à tomada de decisão dos gestores, dessa maneira, o TCU 
passou a exigir, a partir do exercício de 2014, informações relativas à apuração dos custos dos programas e das unidades administrativas de cada UPC.

A partir de então, dentre as informações prestadas anualmente através do Relatório de Gestão ao TCU, apresenta-se um tópico dedicado à "Sistemática de Apuração de Custos no âmbito da Unidade", integrante da seção "Desempenho Financeiro e Informações Contábeis".

De acordo com as orientações do TCU, esse tópico do Relatório de Gestão tem por objetivo "oferecer informações acerca do estágio de desenvolvimento da sistemática de apuração de custos dos programas e unidades administrativas, bem como dos bens e serviços resultantes da atuação da unidade prestadora de contas". A ênfase deve ser dada principalmente aos custos decorrentes da execução dos seus objetivos estratégicos. Para preenchimento das informações de custos no relatório relativo ao exercício de 2016, o TCU exige que sejam explicitados, no mínimo, as informações abaixo:

a) Identificação da estrutura orgânica da unidade responsável pelo gerenciamento de custos (subunidade, setor, etc.), bem como da setorial de custos a que se vincula, se for o caso;

b) Identificação das subunidades administrativas da UPC das quais os custos são apurados;

c) Descrição sucinta do sistema informatizado de apuração dos custos;

d) Práticas de tratamento e alocação utilizados no âmbito das subunidades ou unidades administrativas para geração de informação de custos;

e) Impactos observados na atuação da UPC, bem como no processo de tomada de decisões, que podem ser atribuídos à instituição do gerenciamento de custos;

f) Relatórios utilizados pela UPC para análise e custos e tomada de decisão (TCU, 2016, p.1).

As instruções fornecidas pelo TCU orientam que não há uma estrutura definida para o preenchimento, ficando a critério do gestor a forma mais eficiente de apresentação dos dados, sem deixar de atender alguns aspectos exigidos quanto à natureza da informação.

Na Portaria de orientação emitida pelo TCU, também é considerado o fato de algumas unidades jurisdicionadas não utilizarem o Sistema de Informação de Custos, como os poderes Legislativo e Judiciário e o Ministério Público da União.

Para as unidades integrantes do Poder Executivo que não usam o SIC como principal ferramenta da sistemática de apuração de custos, o TCU requer que sejam 
apresentadas justificativas para a não adoção do sistema disponibilizado, todavia, sem deixar de exigir as informações do sistema de custos adotado pela unidade.

O TCU orienta também, que mesmo que a UPC não possua localmente uma unidade direcionada à atividade de apuração de custos, e que esta atividade seja abrangida por uma setorial superior, a unidade deverá prestar as informações relevantes que forem aplicáveis a sua realidade, o que não a isenta, portanto, de trabalhar suas informações gerenciais de custos.

Essa exigência das informações de custos tem o intuito de permitir uma ampla visão do uso da sistemática de apuração de custos pela unidade, da mesma forma que é feita a interação com a setorial de custos do órgão. Busca-se, principalmente, estimular os atores envolvidos na missão de tratar de custos localmente, dentro da unidade jurisdicionada, para que os recursos públicos sejam utilizados de forma racionalizada e possam atender eficientemente aos anseios dos cidadãos.

No âmbito da UFRA, o relatório de gestão do exercício de 2016 menciona que naquele ano estava sendo promovida pesquisa e capacitação aos servidores da área contábil para que fossem iniciadas as práticas relativas ao gerenciamento dos custos dos seus programas, unidades administrativas e dos serviços oferecidos pela instituição. No relatório de gestão do ano de 2017, a UFRA (UNIVERSIDADE FEDERAL RURAL DA AMAZÔNIA, 2017b) informa que o acesso ao SIC lhe havia sido disponibilizada pelo MEC, e que a partir daí seriam designados os servidores que fariam a apuração das informações de custos e reforça a continuidade dos esforços relacionados às pesquisas e capacitações nesse tema.

Entretanto, a adoção da sistemática de custos em um órgão público vai além do acesso ao sistema informatizado que realiza o cálculo dos custos, é importante que se conheça a estrutura do órgão e as suas reais necessidades gerenciais, para que se possa definir o método de custeio mais adequado e os objetos de custo que se prescinde mensurar. Nesse pensamento, no tópico 2.5 apresentam-se os métodos de custeios e sua aplicabilidade, e posteriormente, as teorias relacionadas aos objetos de custo e os critérios de escolha. 


\subsection{Métodos de Custeio}

Método de custeio diz respeito à composição do valor de custo de um evento, atividade, produto, atributo, etc., ou seja, de uma entidade objeto de custeio de interesse do gestor. A escolha do método que a empresa ou entidade pública utilizará dependerá, em boa parte, do propósito da utilização do sistema (MARTINS; ROCHA, 2010 apud ROMANO, 2015).

Stark (2007) apud Faria (2009, p.8) afirma que "o termo custo, por si só, não possui nenhum significado se não fizer referência a algum objeto, que habitualmente é o produto". Ele alerta para a necessidade de distinguir método de custeio com forma de custeio e sistema de acumulação de custos. Método de custeio indica quais custos farão parte da apuração do custo dos produtos; o sistema ou forma de custeio está ligado à dimensão da unidade de mensuração e indica as opções de mensuração após adotar um método de custeio.

Martins (2003, p.37) define Custeio como "Apropriação de Custos", e que os custos serão alocados de acordo com o método de custeio selecionado. Os métodos de custeio listados por ele são: Absorção, Variável ou Direto, ABC ou Custeio Baseado em atividades, RKW ou Custeio Pleno e Padrão, definidos a seguir.

a) Custeio por Absorção

Mauss e Souza (2008) apud Romano (2015) definem custeio por Absorção como o método que absorve todos os custos de produção, e somente os de produção, de produtos ou serviços produzidos em determinado período. Nesse método apenas os custos de produção são considerados como custo do produto elaborado, os demais gastos são classificados contabilmente como despesas.

A definição de Martins (2003) sobre custeio por absorção corrobora a anterior, afirmando que este método deriva da aplicação dos Princípios de contabilidade aceitos convencionalmente, nascido da situação histórica. O autor reforça que este método de custeio é exigido pelo fisco para as empresas da iniciativa privada, pois agrega ao produto fabricado os custos diretos e indiretos.

No setor público o custeio por absorção não é obrigatório como na área privada, entretanto, é um método bastante conhecido pelos profissionais da 
contabilidade e sua implementação tende a ser realizada de forma mais simples, comparativamente aos demais métodos.

Quadro 10: Vantagens e Desvantagens do Método de Custeio por Absorção

\begin{tabular}{|l|l|}
\hline \multicolumn{1}{|c|}{ Vantagens } & \multicolumn{1}{c|}{ Desvantagens } \\
\hline É bastante utilizado e de fácil aplicação & $\begin{array}{l}\text { Não realiza apuração acurada dos custos aos } \\
\text { objetos de custeio }\end{array}$ \\
\hline $\begin{array}{l}\text { Aceito pelas legislações societária e tributária e } \\
\text { atende aos princípios contábeis geralmente } \\
\text { aceitos }\end{array}$ & Rateios de custos arbitrários e subjetivos \\
\hline $\begin{array}{l}\text { Apuração do custo global de cada produto ou } \\
\text { serviço, pois absorve todos os custos de } \\
\text { produção. }\end{array}$ & $\begin{array}{l}\text { É frágil para eliminação de desperdícios e } \\
\text { adoção de procedimentos de melhoria contínua }\end{array}$ \\
\hline $\begin{array}{l}\text { Agrega todos os custos, tanto diretos como } \\
\text { indiretos, ao objeto de custo }\end{array}$ & $\begin{array}{l}\text { Estabelecimento de estratégias que assegurem } \\
\text { vantagem competitiva }\end{array}$ \\
\hline $\begin{array}{l}\text { Apuração do custo de cada departamento ou } \\
\text { centro de custo }\end{array}$ & $\begin{array}{l}\text { Não possibilita um conhecimento adequado das } \\
\text { reais causas geradoras dos custos }\end{array}$ \\
\hline Permite elaborar planejamento de longo prazo & \\
\hline Implementação mais simples e menos custosa & \\
\hline
\end{tabular}

Fonte: Mauss e Souza (2008) apud Romano (2015, p. 24).

Atualmente, o Governo Federal disponibiliza dados de custos das unidades organizacionais no Portal de Custos do Governo Federal utilizando o método por absorção, sob o argumento que "os custos indiretos são alocados às unidades administrativas, desde que o consumo dos recursos seja relacionado significativamente aos servidores públicos". E que dessa maneira, "não havendo relação entre insumos consumidos e servidores, o elemento de custo não será rateado" (BRASIL. Secretaria do Tesouro Nacional, 2017c, p.9).

b) Custeio Variável

Em relação ao Custeio do tipo Variável, Martins (2003) o define como o método onde são alocados aos produtos os custos variáveis, ficando os fixos separados e considerados como despesas do período, indo diretamente para o Resultado do Exercício; os custos variáveis vão para os estoques como consequência.

Esse método possui bastantes benefícios informacionais internos à organização, entretanto, fere o Regime Contábil da Competência e não é aceito para efeitos de Balanços e Resultados, portanto, não reconhecido pelos Contadores, Auditores Independentes e tampouco pelo fisco. 
Machado (2002) reforça que o uso do Custeio Variável tem sido indicado apenas para relatórios voltados à administração interna, com a finalidade de evidenciar a margem de contribuição por produto, para a tomada de decisão sobre produção, preços praticados aos consumidores, preços especiais voltados a novos mercados.

Quadro 11: Vantagens e Desvantagens do Método de Custeio Variável

\begin{tabular}{|c|c|}
\hline Vantagens & Desvantagens \\
\hline $\begin{array}{l}\text { Não utiliza rateios arbitrários para apropriar } \\
\text { custos diretos }\end{array}$ & $\begin{array}{l}\text { Dificuldade em classificar corretamente os } \\
\text { custos fixos e variáveis }\end{array}$ \\
\hline $\begin{array}{l}\text { Considera as despesas operacionais que } \\
\text { possam ser diretamente associadas aos } \\
\text { produtos ou serviços }\end{array}$ & $\begin{array}{l}\text { Subestima os custos fixos, que estão } \\
\text { associados à capacidade de produção e } \\
\text { planejamento a longo prazo }\end{array}$ \\
\hline Conhecimento da margem de contribuição & $\begin{array}{l}\text { Deficiência no planejamento a longo prazo pode } \\
\text { acarretar em problemas na continuidade da } \\
\text { organização }\end{array}$ \\
\hline $\begin{array}{l}\text { Identificação do mix mais adequado de serviços } \\
\text { a prestar }\end{array}$ & $\begin{array}{l}\text { Fere os princípios contábeis geralmente aceitos } \\
\text { e não é aceito pelas legislações societária e } \\
\text { tributária }\end{array}$ \\
\hline $\begin{array}{l}\text { Maior facilidade em custear serviços, visto que } \\
\text { os dados são próximos da responsabilidade dos } \\
\text { gerentes }\end{array}$ & $\begin{array}{l}\text { Exclusão dos custos fixos indiretos para } \\
\text { valoração de estoques causa sua subavaliação }\end{array}$ \\
\hline $\begin{array}{l}\text { Maior clareza no planejamento dos resultados e } \\
\text { na tomada de decisões }\end{array}$ & $\begin{array}{l}\text { Margem de contribuição pode não permanecer a } \\
\text { mesma em diferentes níveis de atividade }\end{array}$ \\
\hline \multicolumn{2}{|l|}{$\begin{array}{l}\text { Fundamenta decisões de curto prazo, } \\
\text { principalmente no que diz respeito à ociosidade }\end{array}$} \\
\hline $\begin{array}{l}\text { Avaliação mais precisa do desempenho } \\
\text { divisional e global da organização }\end{array}$ & \\
\hline
\end{tabular}

Fonte: Mauss e Souza (2008) apud Romano (2015, p. 24)

Ademais, o Custeio Variável é bastante discutido em relação à sua ampla utilização para relatórios externos. Inúmeros são os argumentos que surgiram a seu favor e contrários, entretanto, Machado (2002) afirma que todos os argumentos que surgiram apenas tangenciam a verdadeira problemática existente entre o Custeio por Absorção e o Custeio Variável, que é a definição se os custos fixos de fabricação são custos do produto fabricado ou do período durante o qual foram incorridos.

c) Custeio Direto

Custeio Direto é aquele que apropria aos produtos apenas os custos diretos, sejam fixos ou variáveis, exige-se apenas que eles sejam perfeitamente identificáveis com o produto. Tal conceito apresenta o produto como foco exclusivo 
do objeto de custeio. Porém, sendo necessário apurar custos de novos agentes de acumulação, este método servirá também para apropriar os custos diretos, sejam eles fixos ou variáveis, independente do objeto de custo, o que importa é que seja de interesse do gestor. Este método de apropriação de custos não permite qualquer tipo de rateio (MACHADO, 2002).

No Custeio Direto, os custos fixos são agregados ao objeto de custeio por serem diretamente identificáveis a este. O Custeio Direto evita os rateios de custos que podem levar a valores infundados, do contrário, leva ao objeto de custeio os custos fixos que o são próprios, além dos custos e despesas variáveis. Vários autores consideram os Métodos de Custeio Variável e Direto como sinônimos, entretanto, para este trabalho serão conceituadas distintivamente, haja vista as definições trazidas pela NBC $\mathrm{T} 16.11$ (CONSELHO FEDERAL DE CONTABILIDADE, 2012), detalhadas no tópico 2.2.1.

Machado e Holanda (2010) defendem a adoção do método de custeio direto no setor público com três argumentos: o primeiro advém do fato desse método não conter qualquer tipo de rateio, permitindo, com isso, analisar o desempenho dos gestores e das políticas públicas com maior objetividade e sem polêmicas a respeito de transferência de custos gerais. O segundo argumento menciona que esse método está entranhado no sistema de planejamento, orçamento e contabilização da execução orçamentária, fator que facilitaria a implantação de um sistema integrado de custos. O último faz relação ao custo-benefício da informação, pois o método de custeio direto facilitaria a uma implantação rápida e com baixo custo de treinamento, considerando que esse método é de uso prático aos profissionais contábeis e gestores.

d) Custeio por Atividades - ABC

O método de custeio $A B C$ ou por Atividades apropria todos os custos e despesas ao produto após análise de todos os processos e atividades necessários, utilizando-se direcionadores de custos em dois estágios: o primeiro, onde o produto consome atividades, o segundo, onde as atividades consomem recursos. Nele é possível alocar todos os custos diretos e indiretos, apesar do seu diferencial ser 0 tratamento aos custos indiretos. É possível obter melhor visualização dos custos através da analise das atividades executadas dentro da empresa e suas respectivas 
relações com os produtos, além da necessidade de definir os direcionadores de custos (GONÇALVES; PARCIANELLO; SOARES, 2015).

Machado (2002) corrobora afirmando que o método ABC primeiro direciona os recursos consumidos nas atividades, de acordo com sua medida de consumo, e após, direciona os custos das atividades aos objetos de custos em conformidade com uma medida de produto da atividade.

Conforme Martins (2003), o Custeio Baseado em Atividades procura reduzir sensivelmente as distorções provocadas por rateios dos custos indiretos realizados de maneira arbitrária. A principal diferença deste método de custeio para os demais é o tratamento dado aos custos indiretos. A utilidade do método $A B C$ não se limita ao custeio de produtos, é uma ferramenta poderosa a ser utilizada na gestão de custos.

Baseado nas definições dos métodos de custeio de Martins (2003), Gnisci (2010) destaca um conjunto de vantagens e desvantagens relacionadas à utilização desta metodologia:

Quadro 12: Vantagens e Desvantagens do Método de Custeio ABC

\begin{tabular}{|l|l|}
\hline \multicolumn{1}{|c|}{ Vantagens } & \multicolumn{1}{c|}{ Desvantagens } \\
\hline $\begin{array}{l}\text { Alinhamento com os Princípios Fundamentais } \\
\text { de Contabilidade }\end{array}$ & Alto custo de implementação \\
\hline $\begin{array}{l}\text { Facilidade de adaptação à temática } \\
\text { empresarial de serviços, pela dificuldade de } \\
\text { definição do que sejam custos, gastos e } \\
\text { despesas nessas organizações }\end{array}$ & $\begin{array}{l}\text { Alto nível de controles internos a serem } \\
\text { implantados e avaliados }\end{array}$ \\
\hline Menor necessidade de rateios arbitrários & Constante necessidade de reavaliação e revisão \\
\hline $\begin{array}{l}\text { Informações gerenciais relativamente mais } \\
\text { fidedignas por meio da redução do rateio }\end{array}$ & Consideração de muitos dados \\
\hline $\begin{array}{l}\text { Obriga a implantação, permanência e revisão } \\
\text { de controles internos }\end{array}$ & Informações de difícil extração \\
\hline $\begin{array}{l}\text { Proporciona melhor visualização dos fluxos } \\
\text { dos processos }\end{array}$ & $\begin{array}{l}\text { Dificuldade de envolvimento e comprometimento } \\
\text { dos empregados da empresa }\end{array}$ \\
\hline $\begin{array}{l}\text { Identifica, de forma mais transparente, onde } \\
\text { os itens em estudo estão consumindo mais } \\
\text { recursos }\end{array}$ & $\begin{array}{l}\text { Necessidade de reorganização da empresa antes } \\
\text { de sua implantação }\end{array}$ \\
\hline $\begin{array}{l}\text { Identifica o custo de cada atividade em relação } \\
\text { aos custos totais da entidade }\end{array}$ & $\begin{array}{l}\text { Dificuldade na integração das informações entre } \\
\text { departamentos }\end{array}$ \\
\hline $\begin{array}{l}\text { Pode ser empregado em diversos tipos de } \\
\text { empresas (industriais, comerciais, de serviços, } \\
\text { com ou sem fins lucrativos) }\end{array}$ & $\begin{array}{l}\text { Falta de pessoal competente, qualificado e } \\
\text { experiente para implantação e acompanhamento }\end{array}$ \\
\hline $\begin{array}{l}\text { Pode, ou não, ser um sistema paralelo ao } \\
\text { sistema de contabilidade }\end{array}$ & $\begin{array}{l}\text { Necessidade de formulação de procedimentos } \\
\text { padrões }\end{array}$ \\
\hline $\begin{array}{l}\text { Pode fornecer subsídios para gestão } \\
\text { econômica, custo de oportunidade e custo de } \\
\text { reposição }\end{array}$ & $\begin{array}{l}\text { Maior preocupação em gerar informações } \\
\text { estratégicas do que em usá-las }\end{array}$ \\
\hline $\begin{array}{l}\text { Possibilita a eliminação ou redução das } \\
\text { atividades que não agregam valor ao produto }\end{array}$ & \\
\hline Fonte: Gnisci 2010, p 35) & \\
\hline
\end{tabular}

Fonte: Gnisci (2010, p. 35) 
Ao se tratar sobre gestão pública, é necessário conceituar atividade como um processo que combina, adequadamente, pessoas, tecnologias, materiais, métodos e seu ambiente, com foco na produção de produtos. Portanto, no método $A B C$, deve ser verificada a ponderação das atividades envolvidas no processo de produção de mercadoria ou de serviço gerado pela administração pública, que seja então reconhecida como objeto de custeio (GNISCI, 2010).

Machado e Holanda (2010) mencionam que o custeio por atividades no setor público possibilita que sejam acompanhados os avanços relativos à gestão por atividades, preocupando-se principalmente com a capacidade não utilizada e com atividades que não agregam valor, buscando reduzir desperdícios e eliminar as atividades desnecessárias. Sua adoção no setor público não encontraria maiores dificuldades, pois toda ação governamental é decomposta em atividades/projetos, sendo, portanto, o elemento-chave nos sistemas de orçamento e de contabilidade.

e) Custeio RKW ou Pleno

O método RKW (Reichskuratorium für wirtschaftlichkeit) ${ }^{4}$ surgiu de técnica disseminada na Alemanha, com o fundamento de usar os custos para fixar preços. A fixação do preço é realizada com base na alocação não somente dos custos, mas também das despesas aos produtos, somando-se então a margem desejada de lucro. Esse método rateia os custos de produção e todas as despesas da empresa, inclusive as financeiras, a todos os produtos. Utilizando este método, chega-se aos custos de "produzir e vender", onde bastaria acrescentar o lucro desejado para obter o preço de final de venda (NEVES; VICECONTI, 2003; GONÇALVES; PARCIANELO; SOARES, 2015).

Martins (2003) ratifica que o método RKW possui técnicas semelhantes às demais estudadas em Custos, principalmente no se refere à apropriação dos custos indiretos de produção, ou seja, o calculado é baseado na alocação dos custos e despesas aos diversos departamentos da empresa e posteriormente executar o rateio de forma que todos os custos e despesas recaiam exclusivamente sobre os produtos fabricados.

\footnotetext{
${ }^{4}$ A tradução de forma literal seria Conselho Administrativo do Império para a Eficiência Econômica.
} 
Neves e Vicenconti (2003) relembram que o método RKW foi utilizado no Brasil na época que existia o CIP - Conselho Interministerial de Preços, que foi o órgão que controlou os preços das empresas nas décadas de 60 e 70. A vantagem maior do RKW é agilidade de calcular o efeito de qualquer aumento de um item de custo ou despesa nos preços dos produtos.

Não foram encontradas experiências ou bibliografias que tratem da utilização deste método na área pública.

\section{f) Custeio Padrão}

Martins (2003) afirma que a institucionalização do Custo-padrão é a maneira mais eficaz de se planejar e controlar custos, que pode ser usado com o Custeio por Absorção e também com o Custeio Variável. Diz respeito ao valor que a empresa fixa como meta para o próximo período para um determinado produto ou serviço, mesmo consciente das dificuldades que enfrentará para alcançar essas metas.

A maior utilidade do Custo-padrão é servir como parâmetro para o controle dos custos reais e um instrumento importante para identificar suas ineficiências. Para alcançar esse objetivo, o Custeio-Padrão não precisa servir de base para os registros contábeis da empresa. As comparações entre o Custo-Real e o Padrão podem ser realizadas de maneira extracontábil, por relatórios especiais (NEVES; VICECONTI, 2003).

O método de Custeio Padrão conforme Gonçalves, Parcianelo e Soares (2015) é determinado a partir de cálculos realizados na etapa de pré-produção, ou seja, é uma presunção dos cálculos da fase de produção.

Machado e Holanda (2010) relatam a importância do custo-padrão para evitar as simples estimativas do custo orçado. Recomenda-se estabelecer padrões para todas as atividades e produtos a serem executados pelo setor público, não na fase inicial do processo de implantação de custos, mas um ideal a ser perseguido pelas instituições. 


\subsection{Objetos de Custo}

Machado (2002) destaca que o objetivo principal das entidades públicas é a produção de bens e serviços para fornecê-los à comunidade. Assim, os bens e serviços devem ser o objeto maior dos estudos dos custos do setor público.

De acordo com a Secretaria do Tesouro Nacional (BRASIL. Secretaria do Tesouro Nacional, 2017d) os objetos de custos têm como finalidade classificar a origem do custo e realizar a sua alocação adequadamente. Possibilita associar uma despesa a um determinado objeto de custos, identificando processos, atividades, produtos ou departamentos, permitindo o levantamento dos objetos do setor público.

O objeto será definido conforme a necessidade latente da organização, e possibilita ao gestor utilizar essa ferramenta de análise com alto grau de detalhamento. Isso ocorre por meio da liquidação da despesa que permite que seja feita a associação ao objeto de custo pretendido. Também é permitida a associação do custo a mais de um tipo de objeto de custo, de acordo com o interesse da unidade (BRASIL. Secretaria do Tesouro Nacional, 2017d).

Um objeto de custo é aquilo de que se deseja obter as informações, quer seja um processo, um bem ou serviço, e será o ponto de convergência dos gastos. $O$ objeto de custo é, portanto, o núcleo das macroatividades da organização, ou vários subitens que compõem esse núcleo. Nesse entendimento, pode-se dizer que o objeto de custo também pode ser um departamento (MORGAN; ROSA, 2006).

A Secretaria do Tesouro Nacional (BRASIL. Secretaria do Tesouro Nacional, 2017d) teceu algumas considerações importantes sobre a melhor forma de definição e composição de um objeto de custo na Administração Pública:

- Deve ocorrer a interação entre todas as áreas do órgão;

- A estrutura do órgão deve ser bem conhecida com a identificação das unidades que o compõe;

- Definir, com maturidade, os objetos de custo a serem analisados pelo órgão;

- Submeter os objetos definidos à autoridade que irá utilizá-los;

- Definir uma política de implantação desses objetos contendo principalmente data, UG pioneira, período de teste, alimentação da tabela, instrução, capacitação interna, etc.;

- Trabalhar em conjunto com a contabilidade é imprescindível. 
A importância do uso da informação de custos a partir dos objetos de custos possibilita, por exemplo, formular a proposta orçamentária do órgão e demais relatórios de propósitos semelhantes baseados em dados mais precisos. Como uma ferramenta de controle pode auxiliar sobremaneira a combater desvios, uso indevido e possíveis desperdícios de recursos públicos. Também possibilita saber o que custa e quanto custa tudo o que é produzido pelo órgão, auxiliando a tomada de decisão no tocante ao processo de criação de novas unidades e/ou produtos.

A Secretaria do Tesouro Nacional (BRASIL. Secretaria do Tesouro Nacional, 2017d) menciona alguns possíveis objetos de custos do setor público:

- Programas

- Ação Projeto / Atividade

- Produto da Ação

- Produto / Serviço

- Processos

- Órgão

- Unidade Gestora

- Departamento

- Macroprocessos

- Custos por Cliente Atendido

- Custos por Processos

A partir da análise dos dados desses ou de outros objetos de custos obtidos através dos relatórios do SIC os gestores terão maior suporte, por exemplo, nas decisões relativas à avaliação, comparação e revisão do Plano Plurianual - PPA ${ }^{5}$ a cada quatro anos, conforme demonstrado na figura 7.

${ }^{5}$ Conforme a Constituição Federal Brasileira no seu art. 165, §1ํㅜ o plano plurianual -PPA estabelecerá de forma regionalizada as diretrizes, objetivos e metas da administração pública federal para as despesas de capital e outras dela decorrentes e para as relativas aos programas de duração continuada. A elaboração do PPA é uma das etapas do processo orçamentário das organizações públicas. 
Figura 7: Ciclo Orçamentário - SIC

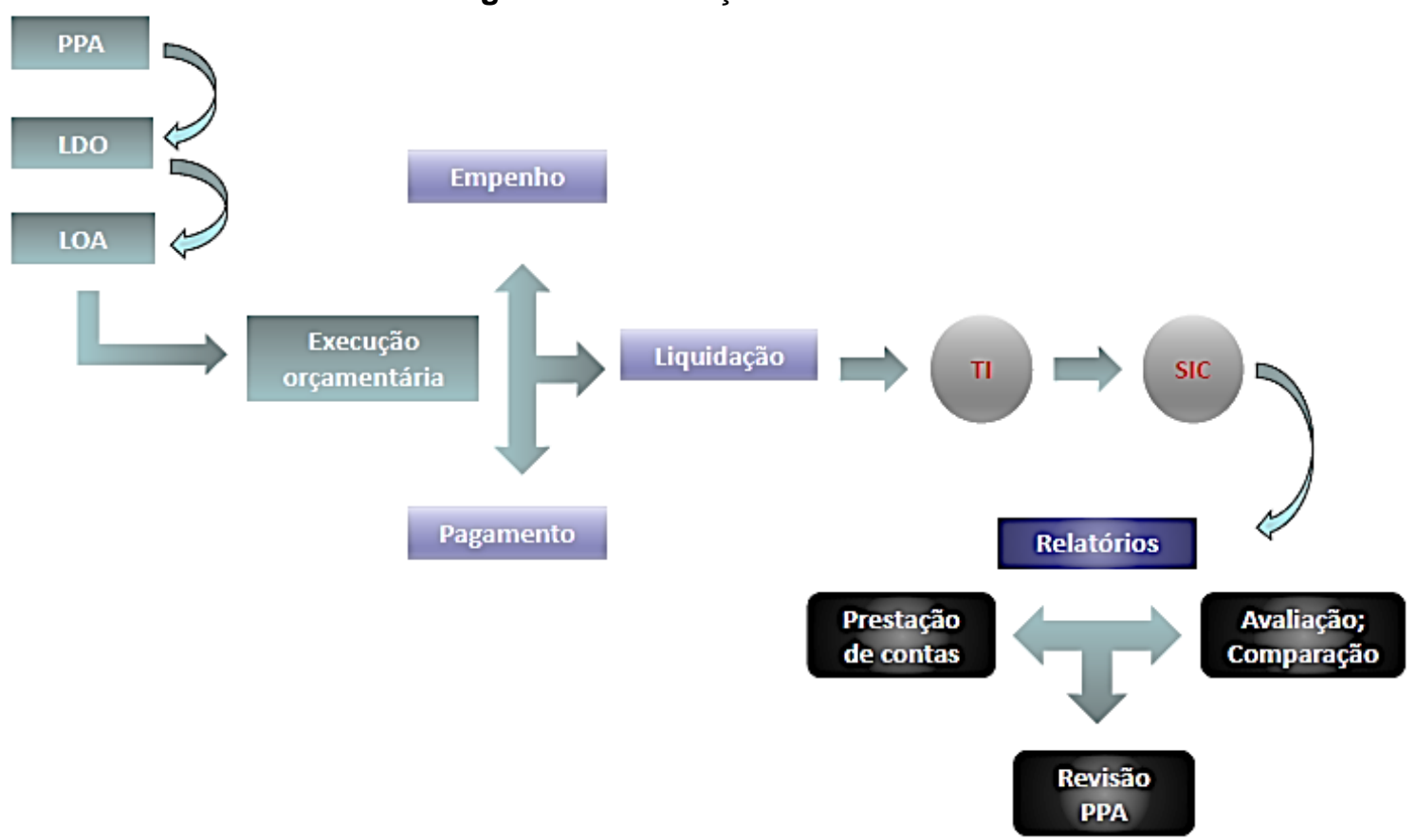

Fonte: Brasil. Secretaria do Tesouro Nacional (2017d).

Ao tratar sobre a avaliação das chamadas peças orçamentárias - PPA, LDO e $\mathrm{LOA}^{6}$ a partir das informações dos relatórios de custos conforme demonstra o ciclo orçamentário do SIC, cabe mencionar que os objetos de custos devem estar previamente definidos no SIC e os dados alocados devidamente alinhados ao conteúdo das peças orçamentárias para que se tenha melhor proveito dos relatórios por parte dos gestores e usuários da informação.

A seguir, no Capítulo III desta pesquisa são apontados os aspectos metodológicos e em seguida será apresentada a análise dos dados da Universidade Federal Rural da Amazônia e da implantação da sistemática de em outros órgãos públicos.

\footnotetext{
${ }^{6}$ Conforme Brasil. Ministério do Planejamento, Desenvolvimento e Gestão (2015a; 2015b) a Lei Orçamentária Anual - LOA define as prioridades contidas no PPA e as metas que deverão ser atingidas pelo governo naquele ano. Disciplina todas as ações governamentais. Todas as despesas públicas devem estar registradas nas Leis Orçamentárias, sejam do governo federal, estadual ou municipal. A Lei de Diretrizes Orçamentárias - LDO estabelece, principalmente, as metas e prioridades para o exercício financeiro seguinte e orienta a elaboração da LOA.
} 


\section{PROCEDIMENTOS METODOLÓGICOS}

Neste capítulo, demonstra-se os procedimentos metodológicos e técnicos da pesquisa, bem como as fontes de dados secundários. Quanto à sua finalidade, a pesquisa é do tipo aplicada, pois busca demonstrar a viabilidade da utilização e os caminhos para a implementação das Informações de Custos como mecanismo de apoio à tomada de decisões na UFRA (KAUARK; MANHÃES; MEDEIROS, 2010).

A análise de custos das entidades privadas ou públicas são prerrogativas do profissional contábil, entretanto, as pesquisas dessa temática perpassam por todas as demais áreas que compõem a organização, como a Administração e a Economia, por isso, esta pesquisa pode ser classificada como interdisciplinar, pois, de acordo com Farias Filho e Cordeiro (2013) é um estudo onde temas de diferentes disciplinas acadêmicas sejam pesquisados tendo uma mesma teoria dando suporte analítico e metodológico.

A presente dissertação, do ponto de vista dos objetivos, é classificada como uma pesquisa exploratória, pois busca aprofundar os aspectos técnicos e legais da utilização da informação de custos no setor público. Gil (1999) explica que esse tipo de pesquisa é realizado especialmente quando o tema é pouco explorado e a formulação de hipóteses é realizada de maneira imprecisa.

A pesquisa do tipo exploratória é comumente utilizada quanto o tema é demasiadamente genérico e requer delimitação e esclarecimentos, exigindo, principalmente, revisão de literatura e discussão com especialistas. Essas características são facilmente identificadas quando se buscam estudos de custos do setor público e sua utilização nas decisões de gestão. Nesse trabalho serão exploradas as experiências de outras entidades que possam servir de modelo para a utilização das informações de custos para as tomadas de decisão na UFRA. Assim como a demonstração do funcionamento do SIC, ferramenta de obtenção das informações.

Quanto à abordagem do problema será feita através de análise qualitativa, pois, conforme Calar, Manhães e Medeiros (2010), a interpretação dos fenômenos e a atribuição de significados são características desse tipo de análise. A demonstração da utilização das ferramentas disponibilizadas pelo Sistema de Informação de Custos, assim como a análise das melhores práticas de órgãos da 
mesma esfera, requer observação empírica, não podendo, portanto, ser mensurada quantitativamente.

Para identificar os principais benefícios da adoção das informações de custos e apresentar as melhores práticas de gestão de custos de outros órgãos, que utilizam o SIC, foram demonstradas as práticas reconhecidamente exitosas de órgãos públicos brasileiros no âmbito federal. Esses relatos foram coletados através de outras pesquisas acadêmicas e de documentos oficiais do Governo Federal.

Através das experiências relatadas foram demonstradas as ferramentas e funcionalidades para obtenção das informações de custos através do SIC, de suma importância para auxiliar o processo decisório por parte dos gestores da UFRA e consequentemente melhorar os indicadores de eficiência, efetividade e economicidade.

As sugestões e estratégias propostas quanto à utilização da Informação de Custos na UFRA foram feitas também com base nas orientações dadas pelos órgãos de controle e fiscalização como o TCU, pela Secretaria do Tesouro Nacional, pelo Ministério da Educação, por especialistas no tema e gestores de outras entidades públicas.

Por fim, os procedimentos técnicos utilizados foram análise documental e bibliográfica, pois foram utilizadas leituras de obras literárias, documentos de órgãos oficiais, relatórios e artigos que tratam do tema pesquisado. O sítio do TCU na internet que contém os relatórios de gestão das suas unidades jurisdicionadas também foi fonte de informações sobre os órgãos da esfera federal que utilizam o SIC e implementaram ações concretas relacionadas ao tema.

Dessa forma, apresenta-se a estrutura organizacional da UFRA e seus dados de cunho orçamentário relativos aos anos de 2015 a 2017, para que se reforce pelo volume de recursos geridos anualmente, a necessidade de adoção de ferramentas de controles de custos. Ademais, serão apresentadas duas experiências bem sucedidas em implementação de estrutura de gestão de custos no setor público, uma utilizando o método de custeio $A B C$ e outra o método por Absorção.

A partir da ponderação dos relatos de experiência demonstrados, das orientações oriundas dos órgãos normativos e de controle e das especificidades da estrutura da UFRA, apresentamos um roteiro de implementação e uma proposta de estrutura de gestão de custos na UFRA. 


\section{ANÁLISE DE DADOS}

\subsection{Caracterização do objeto de estudo}

A Universidade Federal Rural da Amazônia, pessoa jurídica de direito público, foi criada pela Lei $n^{\circ}$ 10.611, de 23 de dezembro de 2002 (BRASIL, 2002), é uma instituição pública de ensino superior vinculada e mantida pelo Ministério da Educação e sua sede localiza-se na cidade de Belém no estado do Pará.

Possui em sua estrutura quatro Institutos de caráter inter, multi e transdisciplinar em áreas do conhecimento, que são: Instituto Sócio Ambiental e Recursos Hídricos (ISARH); Instituto Ciberespacial (ICIBE); Instituto de Ciências Agrárias (ICA); e Instituto de Saúde e Produção Animal (ISPA). Além de três Fazendas Escolas, que servem como local de prática e experimentação científica, localizadas nos municípios paraenses de Igarapé-Açu, Castanhal e Benfica.

Sua estrutura administrativa atual dispõe de sete (7) Pró-Reitorias: de Administração e Finanças (PROAF), de Gestão de Pessoas (PROGEP), de Planejamento e Desenvolvimento Institucional (PROPLADI), de Extensão (PROEX), de Pesquisa e Desenvolvimento Tecnológico (PROPED), de Assuntos Estudantis (PROAES) e de Ensino (PROEN).

Apoiada pelo Plano de Reestruturação e Expansão das Universidades Federais (REUNI), criado pelo Decreto n 6.096 de 14 de abril de 2007 (BRASIL, 2007), a UFRA promoveu sua reestruturação acadêmica e criação de novos cursos de graduação, assim como a implantação de um campus no Município de Paragominas. Os campi localizados em Capanema e Tomé-Açu foram criados com recursos do Ministério da Educação (MEC) oriundos do Plano Nacional da Educação (PNE 2011-2020), que deve continuar apoiando a expansão da UFRA em busca da sua consolidação até 2024, com sete campi, nos municípios de Belém, Capanema, Capitão Poço, Paragominas, Parauapebas, Tomé-Açu e Tailândia (UNIVERSIDADE FEDERAL RURAL DA AMAZÕNIA, 2017a).

Para ilustrar a estrutura administrativa apresenta-se a figura 8 que demonstra o organograma atual da UFRA. Ressalta-se que não há hierarquia entre as unidades que estão subordinadas ao Reitor, foram divididas em duas camadas apenas por questão de visualização, portanto, encontram-se no mesmo nível de subordinação. 
Figura 8: Organograma da UFRA

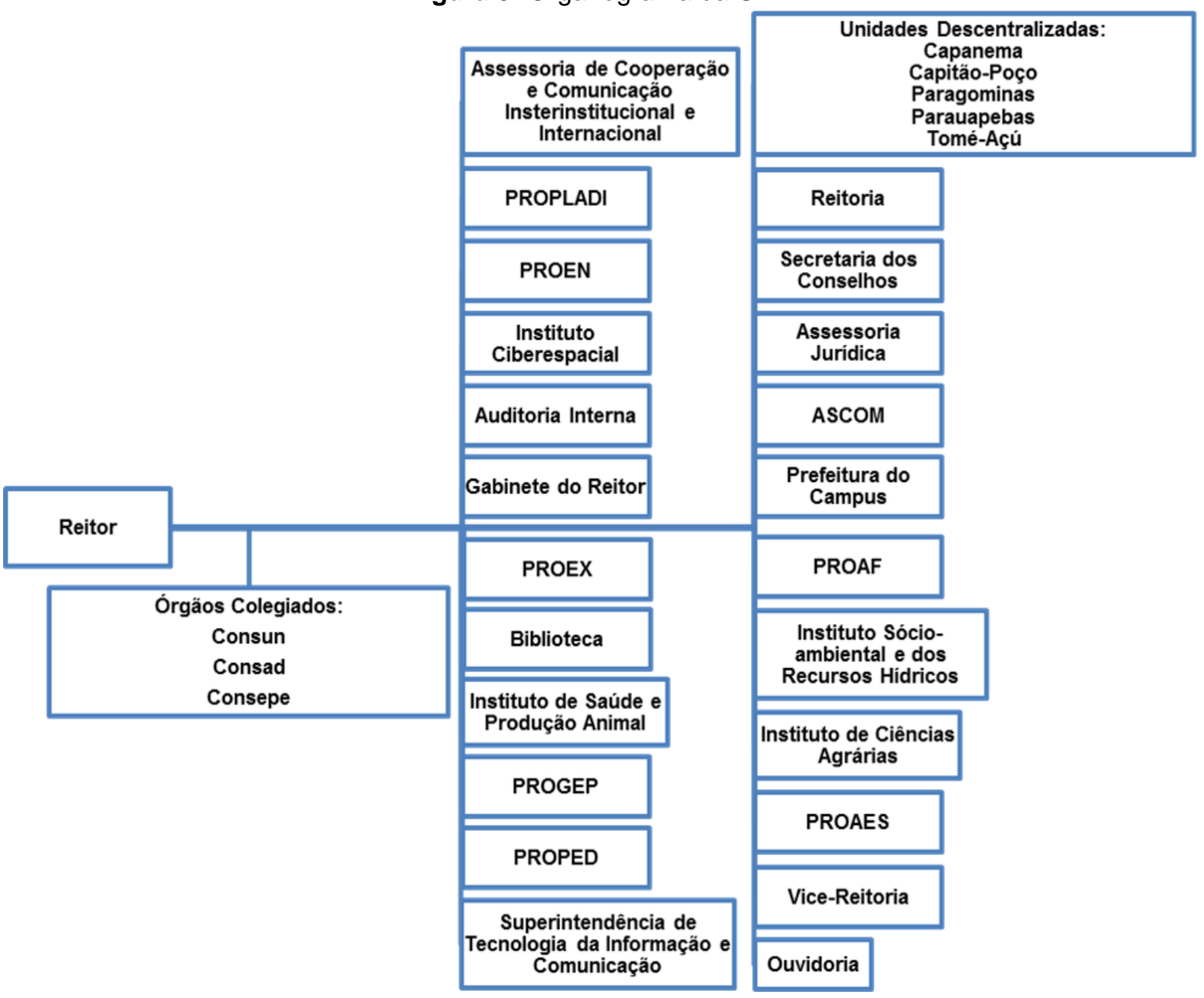

Fonte: Adaptado de Brasil. Sistema de Informações Organizacionais (2018).

A presença de um campus da UFRA no Município de Tailândia-PA, prevista no plano de expansão do seu planejamento estratégico, ainda está em processo de implantação, e prejudicada em parte pelas restrições no orçamento de capital sofridas nos últimos exercícios pelas IFES, conforme será detalhado no tópico seguinte, por essa razão não está contemplado no organograma.

Em seu Planejamento Estratégico 2014-2024, além da expansão física, como uma política de gestão a UFRA também pretende avançar na geração de informação, produção de indicadores consistentes e reveladores do desempenho em todas as áreas, com vistas a integrar a instituição com a sociedade (UNIVERSIDADE FEDERAL RURAL DA AMAZÔNIA, 2014). Ademais, considera-se que a busca da consolidação da UFRA requer que as informações de custos e os indicadores de desempenho sejam utilizados como instrumentos adicionais no 
gerenciamento dos seus recursos orçamentários, e assim alcançar os objetivos determinados em seu plano de longo prazo.

\subsubsection{Desempenho Orçamentário da UFRA no período de 2015 a 2017}

Para auxiliar na análise dos dados orçamentários da UFRA, foram extraídas as informações dos exercícios de 2015 a 2017 através dos relatórios de gestão dos anos de 2016 e 2017, com o intuito de demonstrar o planejamento e a execução das despesas da UFRA de uma maneira geral, as formas de contratação, assim como analisar a evolução desses valores ao longo dos anos mencionados e evidenciar os totais de cada grupo de despesa. Essas informações servirão de fonte para apontar os grupos de despesa que requerem maior atenção e o estudo de custos poderá servir de auxílio para o melhor desempenho daquele grupo.

Foi utilizada a técnica da Análise Horizontal ${ }^{7}$ para demonstrar a evolução das despesas em relação ao primeiro ano tomado como referência, que neste trabalho é o ano de 2015, considerando que uma grande quantidade de anos analisados não contribuiria para uma análise objetiva dos dados extraídos. Ademais, com a implantação no Novo Plano de Contas Aplicado ao Setor Público (PCASP), no ano de 2015, a tarefa de análise das informações obtidas será facilitada pela uniformidade existente entre as contas contábeis nos três anos.

A análise das informações orçamentárias, bem como, a adequação dessas informações às premissas de custos do setor público, atendem ao disposto na NBC T 16.11 (CONSELHO FEDERAL DE CONTABILIDADE, 2012, grifo nosso) no item 20, que orienta:

\footnotetext{
O SICSP deve estar integrado com o processo de planejamento e orçamento, devendo utilizar a mesma base conceitual se se referirem aos mesmos objetos de custos, permitindo assim o controle entre o orçado e o executado. No início do processo de implantação do SICSP, pode ser que o nível de integração entre planejamento, orçamento e execução (consequentemente custos) não esteja em nível satisfatório. O processo de mensurar e evidenciar custos deve ser realizado sistematicamente, fazendo da informação de custos um vetor de alinhamento e aperfeiçoamento do planejamento e orçamento futuros.
}

7 Conforme Montoto (2015, p.1021), a análise das demonstrações financeiras ocorre pela comparação de valores entre contas ou grupos de contas em determinado período ou em exercícios diferentes. Quando a composição dos dados analisados for relativa a exercícios diferentes se está realizando uma análise horizontal. 
A princípio verificou-se a evolução do orçamento da UFRA dos exercícios de 2015 a 2017 separados por grupo de despesa. Os dados apresentados, na tabela 3, apontam redução significativa (55\%) no orçamento de investimentos e pouco crescimento nos recursos para custear as despesas correntes (4\%) no exercício de 2017, comparativamente ao exercício de 2015.

Tabela 1 - Evolução do orçamento anual da UFRA por grupo de despesa

\begin{tabular}{lccccr}
\hline \multicolumn{5}{c}{ Orçamento Fiscal e da Seguridade Social } \\
\hline Exercício & $\mathbf{2 0 1 7}$ & \multicolumn{1}{c}{ AH } & $\mathbf{2 0 1 6}$ & AH & \multicolumn{2}{c}{$\mathbf{2 0 1 5}$} \\
$\begin{array}{l}\text { Pessoal e Encargos } \\
\text { Sociais }\end{array}$ & 144.115 .540 & $30 \%$ & 124.936 .680 & $12 \%$ & 111.189 .360 \\
Outras Despesas & & & & & \\
Correntes & 40.032 .025 & $4 \%$ & 37.727 .673 & $-2 \%$ & 38.512 .941 \\
Investimentos & 3.721 .784 & $-55 \%$ & 7.534 .221 & $-9 \%$ & 8.249 .656 \\
Total & 187.869 .349 & $19 \%$ & 170.198 .574 & $8 \%$ & 157.951 .957 \\
\hline
\end{tabular}

Fonte: Elaboração Própria, 2018

A evolução do orçamento da UFRA, após verificação dos dados dos últimos exercícios financeiros encerrados, apresenta perdas relevantes no grupo de despesa de Investimentos. Essas restrições orçamentárias sofridas pela Administração Federal como um todo, frustraram em parte as pretensões de crescimento da UFRA, entretanto, esse fato deve servir de incentivo à gestão da UFRA para avançar nos estudos relacionados à melhoria da qualidade do gasto, pois, a partir disso, o crescimento pretendido pode ser alcançado mediante um cenário de melhor distribuição de recursos e otimização de despesas.

Nesse pensamento, e buscando-se identificar a distribuição detalhada do orçamento, o Quadro 13 analisa o orçamento aprovado para a UFRA por Função, Subfunção e Programa Orçamentário dos anos de 2015 a 2017.

No detalhamento apresentado por "função" relativo ao exercício de 2017 em comparação aos exercícios de 2016 e 2015, pode-se identificar a previsão orçamentária dos gastos com Previdência Social e Educação, e no detalhamento por "Subfunção" como esses valores são distribuídos. É relevante observar que o orçamento para o "Programa de Gestão e Manutenção do MEC" obteve crescimento significativo de 28\% ao comparar os exercícios de 2015 e 2017, o ressalta a importância da gestão efetiva deste recurso. 
Quadro 13: Evolução do orçamento anual da UFRA detalhado Evolução do Orçamento da UFRA aprovado na LOA

\begin{tabular}{|c|c|c|c|c|c|}
\hline Exercício Financeiro & 2017 & $\mathbf{A H}$ & 2016 & $\mathbf{A H}$ & 2015 \\
\hline$\overline{\text { Total }}$ & 187.869 .349 & $19 \%$ & 170.198 .574 & $8 \%$ & 157.951 .957 \\
\hline \multicolumn{6}{|c|}{ Programa } \\
\hline $\begin{array}{l}\text { Previdência de Inativos e } \\
\text { Pensionistas da União }\end{array}$ & 33.193 .729 & $31 \%$ & 29.452 .761 & $16 \%$ & 25.427 .402 \\
\hline $\begin{array}{l}\text { Operações Especiais: } \\
\text { Sentenças Judiciais }\end{array}$ & 535.168 & $652 \%$ & - & $-100 \%$ & 71.155 \\
\hline $\begin{array}{l}\text { Operações } \quad \text { Especiais: } \\
\text { Participação Organismos }\end{array}$ & 25.000 & $100 \%$ & 20.000 & $100 \%$ & - \\
\hline Educação Básica & - & $-100 \%$ & - & $-100 \%$ & 636.494 \\
\hline Educação Superior & - & $-100 \%$ & - & $-100 \%$ & 40.376 .338 \\
\hline $\begin{array}{l}\text { Educação de qualidade } \\
\text { para todos }\end{array}$ & 36.695 .481 & $100 \%$ & 39.465 .858 & $100 \%$ & - \\
\hline $\begin{array}{l}\text { Programa de Gestão e } \\
\text { Manutenção do MEC }\end{array}$ & 117.419 .971 & $28 \%$ & 101.259 .955 & $11 \%$ & 91.440 .568 \\
\hline \multicolumn{6}{|c|}{ Função } \\
\hline Previdência Social & 33.193 .729 & $31 \%$ & 29.452 .761 & $16 \%$ & 25.427 .402 \\
\hline Educação & 154.115 .452 & $16 \%$ & 140.725 .813 & $6 \%$ & 132.453 .400 \\
\hline Encargos Especiais & 560.168 & $687 \%$ & 20.000 & $-72 \%$ & 71.155 \\
\hline \multicolumn{6}{|c|}{ Subfunção } \\
\hline Administração Geral & - & $-100 \%$ & 15.456 .123 & $25 \%$ & 12.350 .000 \\
\hline $\begin{array}{l}\text { Formação de Recursos } \\
\text { Humanos }\end{array}$ & 372.800 & $-20 \%$ & 466.000 & $0 \%$ & 466.000 \\
\hline $\begin{array}{l}\text { Previdência do Regime } \\
\text { Estatutário }\end{array}$ & 33.193 .729 & $31 \%$ & 29.452 .761 & $16 \%$ & 25.427 .402 \\
\hline Atenção Básica & 1.350 .108 & $1 \%$ & 1.178 .796 & $-12 \%$ & 1.339 .140 \\
\hline $\begin{array}{l}\text { Proteção e Benefícios ao } \\
\text { Trabalhador }\end{array}$ & 5.310 .420 & $35 \%$ & 4.109 .640 & $4 \%$ & 3.944 .625 \\
\hline Ensino Superior & 129.801 .224 & $14 \%$ & 119.515 .254 & $5 \%$ & 113.717 .141 \\
\hline Educação Básica & - & $-100 \%$ & - & $-100 \%$ & 636.494 \\
\hline $\begin{array}{ll}\text { Outros } & \text { Encargos } \\
\text { Especiais } & \end{array}$ & 17.841 .068 & $24974 \%$ & 20.000 & $-72 \%$ & 71.155 \\
\hline
\end{tabular}

Fonte: Elaboração própria, 2018.

Ademais, ao se analisar o orçamento efetivamente executado, um nível maior de detalhamento será crucial para uma análise mais consistente. Essa exigência se faz em atendimento à NBC T 16.11 (CONSELHO FEDERAL DE CONTABILIDADE, 
2012), no item 12, que orienta que a informação de custos tenha a granularidade como um dos seus atributos. Esse atributo faz referência ao fato do sistema utilizado produzir informações em vários níveis de detalhes, através de diferentes relatórios, sem que se perca o atributo da comparabilidade. Ou seja, deve-se buscar o menor nível de detalhamento possível de cada objeto de custo que se deseja analisar.

O Quadro 14 demonstra as despesas orçamentárias executadas e as despesas pagas dos exercícios de 2016 e 2017. As despesas executadas são relativas às despesas liquidadas ou em fase de liquidação, enquanto as despesas pagas são aquelas que concluíram a fase de desembolso financeiro aos credores.

Essa diferenciação deve existir em razão do impacto no Balanço Geral da União - BGU dos pagamentos realizados no exercício seguinte à realização da despesa, refletindo na análise nos demonstrativos contábeis.

Independente do momento do pagamento, não haverá reflexo na análise de custos, pois esta agrega somente aquelas despesas que passaram pela fase de liquidação, portanto aquelas aqui apresentadas como despesa executada.

Quanto às despesas executadas pela UFRA nos exercícios financeiros de 2016 e 2017, o Quadro 14 traz as principais modalidades de contratação utilizadas, com destaque para a modalidade de licitação "Pregão" e para a despesa de "Pagamento em Folha".

Quadro 14 - Despesas totais por modalidade de licitação dos anos de 2016 e 2017.

\begin{tabular}{|c|c|c|c|c|c|c|c|c|}
\hline \multirow[t]{2}{*}{ Modalidade de Contratação } & \multicolumn{4}{|c|}{ Despesa Executada } & \multicolumn{4}{|c|}{ Despesa Paga } \\
\hline & 2017 & $\%$ & 2016 & $\%$ & 2017 & $\%$ & 2016 & $\%$ \\
\hline $\begin{array}{l}\text { 1. Modalidade de Licitação } \\
(a+b+c+d+e+f+g)\end{array}$ & $24.669 .708,50$ & 11,83 & $21.230 .138,94$ & 12,24 & $19.675 .260,62$ & 9,79 & 14.434.268,87 & 8,85 \\
\hline a) Convite & 0,00 & 0,00 & 0,00 & 0,00 & 0,00 & 0,00 & 0,00 & 0,00 \\
\hline b) Tomada de Preços & $67.940,65$ & 0,28 & 2,00 & 0,00 & 0,00 & 0,00 & 0,00 & 0,00 \\
\hline c) Concorrência & 0,00 & 0,00 & 0,00 & 0,00 & 0,00 & 0,00 & 0,00 & 0,00 \\
\hline d) Pregão & $24.536 .940,39$ & 99,46 & $20.639 .960,61$ & 97,22 & $19.610 .433,16$ & 99,67 & $14.307 .060,32$ & 99,12 \\
\hline e) Concurso & 0,00 & 0,00 & $10.000,00$ & 0,05 & 0,00 & 0,00 & $10.000,00$ & 0,07 \\
\hline f) Consulta & 0,00 & 0,00 & 0,00 & 0,00 & 0,00 & 0,00 & 0,00 & 0,00 \\
\hline $\begin{array}{l}\text { g) Regime diferenciado de } \\
\text { contratações públicas }\end{array}$ & $64.827,46$ & 0,26 & $580.176,33$ & 2,73 & $64.827,46$ & 0,33 & $117.208,55$ & 0,81 \\
\hline 2. Contratações diretas $(\mathrm{h}+\mathrm{i})$ & $16.464 .176,05$ & 7,90 & $14.283 .800,17$ & 8,24 & $13.999 .602,29$ & 6,96 & $10.793 .612,40$ & 6,62 \\
\hline h) Dispensa & $15.775 .327,35$ & 95,82 & $13.476 .276,70$ & 94,35 & $13.362 .529,88$ & 95,45 & $10.249 .843,81$ & 94,96 \\
\hline i) Inexigibilidade & $688.848,70$ & 4,18 & $807.523,47$ & 5,65 & $637.072,41$ & 4,55 & $543.768,59$ & 5,04 \\
\hline 3. Regime de Execução Especial & 0,00 & 0,00 & 0,00 & 0,00 & 0,00 & 0,00 & 0,00 & 0,00 \\
\hline j) Suprimento de fundos & 0,00 & 0,00 & 0,00 & 0,00 & 0,00 & 0,00 & 0,00 & 0,00 \\
\hline 4. Pagamento de Pessoal $(\mathrm{k}+\mathrm{l})$ & $167.347 .070,10$ & 80,27 & $137.895 .372,08$ & 79,52 & $167.347 .070,10$ & 83,25 & $137.895 .372,08$ & 84,53 \\
\hline k) Pagamento em Follha & $166.139 .399,85$ & 99,28 & $136.857 .133,88$ & 99,25 & $166.139 .399,85$ & 99,28 & $136.857 .133,88$ & 99,25 \\
\hline 1) Diárias & $1.207 .670,25$ & 0,72 & $1.038 .238,20$ & 0,75 & $1.207 .670,25$ & 0,72 & $1.038 .238,20$ & 0,75 \\
\hline $\begin{array}{l}\text { 5. Total das despesas acima } \\
(1+2+3+4)\end{array}$ & $208.480 .954,65$ & 100,00 & $173.409 .311,19$ & 100,00 & 201.021.933,01 & 100,00 & $163.123 .253,35$ & 100,00 \\
\hline 6. Total das despesas da UPC & $208.480 .954,65$ & 100,00 & $173.409 .311,19$ & 100,00 & $201.021 .933,01$ & 100,00 & $163.123 .253,35$ & 100,00 \\
\hline
\end{tabular}

Fonte: Universidade Federal Rural da Amazônia (2017b, p.30) 
No exercício de 2017, conforme demonstrado no quadro 14, as despesas efetivamente executadas pela UFRA alcançaram o montante de $R \$ 208$ milhões, englobando despesas com pessoal, aquisição de materiais permanentes, de consumo, obras e serviços. Em relação ao exercício de 2016, o montante executado foi de $R \$ 174$ milhões, e o crescimento em 2017 foi de 17\% motivado pelo crescimento das aquisições de materiais e serviços e, principalmente, pelo aumento das despesas com a folha de pagamento de pessoal num quociente de $21 \%$.

O aumento significativo das despesas com a folha de pagamento da UFRA, no exercício de 2017, justifica-se principalmente, pela melhoria do desempenho dos serviços executados à comunidade acadêmica.

O quadro 15 apresenta as despesas da UFRA classificadas por grupo e elemento de despesa dos anos de 2015 e 2016, e reforça que as despesas com Pessoal, nos últimos anos, é o grupo de despesa com maior montante empenhado e liquidado. No ano de 2016 essa rubrica representou $72,64 \%$ do total de $R \$$ 188.386.343,71 de despesas empenhadas, acompanhada de outras despesas correntes com $24,52 \%$ e investimentos com $2,84 \%$.

Quadro 15: Totais por grupo e elemento de despesa nos exercícios de 2015 e 2016

\begin{tabular}{|c|c|c|c|c|c|c|c|c|}
\hline \multicolumn{9}{|c|}{ DESPESAS CORRENTES } \\
\hline Grupes de Despesa & \multicolumn{2}{|c|}{ Empenhada } & \multicolumn{2}{|c|}{ Liquidada } & \multicolumn{2}{|c|}{ KP alo processados } & \multicolumn{2}{|c|}{ Valores Pagos } \\
\hline 1. Pessoal & 2015 & 2016 & 2015 & 2016 & 2015 & 2016 & 2015 & 2016 \\
\hline $\begin{array}{l}\text { 3190.11 - Vencimentos e vantagens furas - } \\
\text { pessoal chill }\end{array}$ & $81.949 .334,27$ & $88.331 .420,62$ & $81.949 .334,27$ & $88.331 .420,62$ &. & $\cdot$ & $81.949,334,27$ & $88.331 .420,62$ \\
\hline $\begin{array}{l}3190.01 \text { - Aposentadioria, reserva remunerada } \\
\text { e reformas }\end{array}$ & $19.573 .037,70$ & $20.871 .824,39$ & $19.573 .037,70$ & $20.871 .824,39$ & $\cdot$ & $\cdot$ & $19.573 .037,70$ & $20.871 .824,39$ \\
\hline Demais elementos do gnipo & $24,984,095,26$ & $27.653 .888,87$ & $24,984,095,26$ & $27.653 .888,87$ & - & - & $24,984,095,26$ & $27.653 .888,87$ \\
\hline \multicolumn{9}{|l|}{ 3. Outras Despesas Correntes } \\
\hline $\begin{array}{l}3390,39 \text { - Senvicos de terceiros - Dessoa } \\
\text { furidica }\end{array}$ & - & - & - & - & - & $3.824,954,71$ & - & - \\
\hline 3390.30 - Material de consumo & - & - & - & - & - & $790.125,81$ & - & - \\
\hline 3390.37 - Locação de mão-de-obrna & - & - & - & - & - & $499.679,45$ & - & - \\
\hline Demais elementos do gnpo & 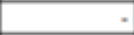 & - & 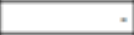 & $=$ & - & $265.634,86$ & $=$ & - \\
\hline $\begin{array}{l}3390,39 \text { - Serviços de ferceíros - Desssoa } \\
\text { furidica }\end{array}$ & - & - & - & - & $6.114 .494,11$ & - & - & - \\
\hline $3390.30-$ Material de consumo & - & - & - & - & $1.089 .089,81$ & - & - & - \\
\hline 3390.18 - Auxilio Financeitro a Estudantes & - & - & - & - & $450.000,00$ & - & - & - \\
\hline Demais elementos do gnpo & 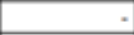 & - & - & - & $180,351,36$ & - & $=$ & 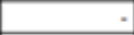 \\
\hline 3390.37 - Locạ̧ào de mäo-de-obra & $16.999 .090,71$ & $15.361 .930,88$ & $16.962 .263,12$ & $14.862 .251,43$ & - & - & $14.785 .621,88$ & $14.862251,43$ \\
\hline $\begin{array}{l}3390.39 \text { - Serviços de tercetinos - Desstod } \\
\text { jeridica }\end{array}$ & $12.851 .134,93$ & 11.317 .434 .97 & $6.736 .640,82$ & $7.492 .480,26$ & $=$ & - & $6.036 .456,70$ & $7.133 .654,02$ \\
\hline $3390.46-$ Ancrilitio altimentaģão & $3.446 .640,96$ & $4.472 .287,73$ & 3.446 .640 .96 & $4.472 .287,73$ & -1 & - & $3.446 .640,96$ & $4.472 .287,73$ \\
\hline 3390.18 - Awxilio financetro a esmidantes & $2.520 .052,49$ & $3.373 .361,54$ & $2.070 .052,49$ & $3.253 .538,04$ & - & - & $2.070 .052,49$ & $3.251 .688,04$ \\
\hline Demais elementor do gropo & 8.109 .669 .16 & $11.671 .756,90$ & $6.877 .055,58$ & $10.735 .819,73$ & - & - & $6.802 .021,72$ & $10.477 .646,40$ \\
\hline \multicolumn{9}{|c|}{ DESPESAS DE CAPITAL } \\
\hline Grupos de Despesa & \multicolumn{2}{|c|}{ Empenahada } & \multicolumn{2}{|c|}{ Liq̨uidada } & \multicolumn{2}{|c|}{ RP aล̄o Procentados } & \multicolumn{2}{|c|}{ Valores Pages } \\
\hline 4. Investimentos & 2015 & 2016 & 2015 & 2016 & 2015 & 2016 & 2015 & 2016 \\
\hline 4490.51 - Obras e instralações & $3.298 .897,84$ & - & - & - & - & - & - & - \\
\hline Demais elementos do gnipo & $1.434 .526,16$ & - & - & - & - & - & - & - \\
\hline $\begin{array}{l}\text { 4590. } 39 \text { - Outros tenvicos de terceirot - } \\
\text { pessoa juridica }\end{array}$ & 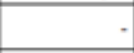 & - & 1.064 .799 .99 & - & - & - & $916.634,60$ & - \\
\hline Demais elementos do gnipo & - & - & $341.817,58$ & $=$ & $=$ & $=$ & $340.572,08$ & $=$ \\
\hline $\begin{array}{l}4490.52 \text { - Equipamentos e material } \\
\text { permanente }\end{array}$ & - & - & - & $\cdot$ & - & $3993,575,82$ & 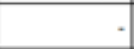 & $\cdot$ \\
\hline 4490.51 - Obras e instalaçōes & - & - & - & - & $3,147,832,53$ & 462967,78 & - & - \\
\hline $\begin{array}{l}4490.39 \text { - Onaros semicos de serceiros - } \\
\text { pessoa juridica }\end{array}$ & - & $*$ & - & $\cdot$ & $174,000,00$ & $\cdot$ & $\cdot$ & $\cdot$ \\
\hline $\begin{array}{l}4490.52 \text { - Equipamentos e material } \\
\text { permanente }\end{array}$ & - & $4.646 .172,98$ & - & $652.597,16$ & 4973,90 & - & & $619.747,16$ \\
\hline Demais elementos do gnipo & - & 686.264 .83 & - & $223.297,05$ & - & - & $=$ & $223.297,05$ \\
\hline
\end{tabular}

Fonte: Universidade Federal Rural da Amazônia (2017a, p. 15-16). 
Ao analisar as despesas através do quadro 15 é possível destacar que nos anos de 2015 e 2016 o elemento de despesa "Locação de Mão-de-obra" foi o item com maior montante empenhado dentro do grupo das Despesas Correntes. Nesse total estão inseridos os gastos com serviços de limpeza e conservação, apoio administrativo e o mais representativo, a vigilância armada.

Os gastos com contratação de serviços terceirizados relativos, principalmente, à locação de mão-de-obra, tendem a manter montantes de grande expressividade nos próximos exercícios, considerando que as atividades desenvolvidas como vigilância armada, serviço de recepcionista, eletricista, mecânico, motorista, e etc. são cargos já extintos ou em extinção, conforme as Leis no 9.632/98 e no 13.328/2016 e o Decreto ํㅜ 9.262/18.

Os serviços classificados como locação de mão-de-obra são considerados essenciais ao funcionamento da UFRA, considerando as especificidades da sua natureza "Agrária". Ademais, como uma tendência do aspecto gerencialista da gestão, deve haver, de forma constante, a busca por alternativas que ofereçam os mesmos serviços, com os mesmos ou melhores resultados, porém, com preços menores aos praticados nos contratos em execução.

Nesse aspecto, o Benchmarking serve como um importante processo de comparação de serviços, produtos e práticas de outras organizações públicas e privadas, que podem trazer à UFRA alternativas mais econômicas do que as contratadas nos últimos anos.

Em 2015 e 2016, os Serviços de Terceiros - Pessoa Jurídica também apresentaram um somatório relevante dentre os elementos de despesa empenhados e liquidados no grupo de Despesas Correntes. Nesse grupo de elementos de despesas, o consumo de energia elétrica é o mais representativo.

No Quadro 16 são apresentadas as despesas empenhadas e liquidadas relativas ao exercício de 2017, em comparação ao de 2016 . Merece destaque o crescimento de $100 \%$ das despesas com Serviços de Terceiros - Pessoa Jurídica, justificado pela obtenção de recursos oriundos do orçamento de outros ministérios para a execução de projetos na UFRA. 
Quadro 16: Totais das despesas por grupo e elemento de despesa exercícios de 2016 e 2017

\begin{tabular}{|c|c|c|c|c|c|c|c|c|}
\hline \multicolumn{9}{|c|}{ DESPESAS CORRENTES } \\
\hline Grupos de despesa & \multicolumn{2}{|c|}{ Empenhada } & \multicolumn{2}{|c|}{ Liquidada } & \multicolumn{2}{|c|}{ RP não processados } & \multicolumn{2}{|c|}{ Valores Pagos } \\
\hline 1. Pessoal & 2016 & 2017 & 2016 & 2017 & 2016 & 2017 & 2016 & 2017 \\
\hline $\begin{array}{l}3190.11-\text { Vencimentos } \\
\text { vantagens fixas - pessoal civil }\end{array}$ & $88.331 .420,62$ & $107.137 .988,73$ & $88.331 .420,62$ & $107.137 .988,73$ & - & - & $88.331 .420,62$ & $107.137 .988,73$ \\
\hline $\begin{array}{l}3190.01 \text { - Aposentadoria, reserva } \\
\text { remunerada e reformas }\end{array}$ & $20.871 .824,39$ & $25.766 .141,97$ & $20.871 .824,39$ & $25.766 .141,97$ & - & - & $20.871 .824,39$ & $25.766 .141,97$ \\
\hline Demais elementos do grupo & $27.653 .888,87$ & $33.235 .269,15$ & $27.653 .888,87$ & $33.235 .269,15$ & - & - & $27.653 .888,87$ & $33.235 .269,15$ \\
\hline \multicolumn{9}{|l|}{ 3. Outras Despesas Correntes } \\
\hline $\begin{array}{l}3390.18 \text { - Auxílio Financeiro a } \\
\text { Estudantes }\end{array}$ & $3.373 .361,54$ & - & $3.253 .538,04$ & - & $119.823,50$ & - & $3.251 .688,04$ & - \\
\hline 3390.30 - Material de Consumo & - & - & - & - & $790.125,81$ & - & - & - \\
\hline $\begin{array}{l}3390.37 \text { - Locação de mão-de- } \\
\text { obra }\end{array}$ & $15.361 .930,88$ & $13.196 .040,12$ & $14.862 .251,43$ & $13.164 .929,12$ & $499.679,45$ & $31.111,00$ & $14.862 .251,43$ & $12.450 .551,01$ \\
\hline $\begin{array}{l}3390.39 \text { - Serviços de terceiros - } \\
\text { pessoa jurídica }\end{array}$ & $11.439 .524,82$ & $17.413 .098,64$ & $7.614 .120,11$ & $15.174 .092,03$ & $3.825 .404,71$ & $2.239 .006,61$ & $7.255 .293,87$ & $14.684 .046,47$ \\
\hline 3390.46 - Auxílio alimentação & $4.472 .287,73$ & - & $4.472 .287,73$ & - & - & - & $4.472 .287,73$ & - \\
\hline $\begin{array}{l}3390.92-\quad \text { Despesas de } \\
\text { Exercícios Anteriores }\end{array}$ & 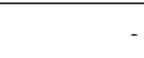 & $3.786 .166,89$ & 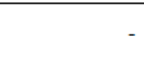 & $3.780 .357,73$ & - & $5.809,16$ & - & $3.712 .417,08$ \\
\hline Demais elementos do grupo & $11.549 .677,05$ & $13.331 .366,52$ & $10.614 .179,88$ & $11.363 .706,59$ & $145.361,36$ & $1.967 .659,93$ & $10.356 .006,55$ & $11.316 .579,07$ \\
\hline \multicolumn{9}{|c|}{ DESPESAS DE CAPITAL } \\
\hline Grupos de despesa & \multicolumn{2}{|c|}{ Empenhada } & \multicolumn{2}{|c|}{ Liquidada } & \multicolumn{2}{|c|}{ RP não processados } & \multicolumn{2}{|c|}{ Valores Pagos } \\
\hline 4. Investimentos & 2016 & 2017 & 2016 & 2017 & 2016 & 2017 & 2016 & 2017 \\
\hline 4490.51 - Obras e instalaç̧ões & - & - & - & - & $462.967,78$ & - & - & - \\
\hline $\begin{array}{l}4490.52 \text { - Equipamentos } e \\
\text { material permanente }\end{array}$ & $4.646 .172,98$ & $3.414 .956,34$ & $652.597,16$ & $1.634 .938,22$ & $3.993 .575,82$ & $1.780 .018,12$ & $619.747,16$ & $1.410 .238,74$ \\
\hline Demais elementos do grupo & $686.264,83$ & $143.010,07$ & $223.297,05$ & $143.010,07$ & - & - & $223.297,05$ & $143.010,07$ \\
\hline
\end{tabular}

Fonte: Universidade Federal Rural da Amazônia (2017b, p. 20)

No grupo de despesa Investimentos, em 2016 a despesa com aquisição de equipamentos diversos foi o elemento com maior montante empenhado com o total de $\mathrm{R} \$ 4.646 .172,98$. Ao comparar com o ano de 2017, o montante empenhado foi de $\mathrm{R} \$ 3.914 .956,34$ apresentando uma redução de $18,7 \%$, causado pela redução dos recursos na LOA para despesas de investimentos.

Martins (2003, p.17) define Investimentos como o "Gasto ativado em função de sua vida útil ou de benefícios atribuíveis a futuro(s) período(s)". O autor afirma que os maquinários e equipamentos são gastos classificados como investimentos permanentes, e parceladamente são transformados em custo através da depreciação à medida que é utilizada pela entidade.

Os investimentos que são realizados pela UFRA, giram, principalmente, em torno de aquisições de equipamentos e material permanente, assim como Obras e Instalações. Para realização a apuração dos custos totais do órgão, essas despesas de Capital devem ser excluídas da apuração, entrando na base somente as despesas com depreciação desses ativos, conforme demonstrado na figura 4 .

Considerando que para fins de análise de custos, especificamente nos órgãos públicos, importam as despesas efetivamente liquidadas, demonstra-se no Quadro 17 a evolução das despesas dos anos de 2015 a 2017 e o percentual de evolução. $O$ intuito é demonstrar o montante de recursos geridos pela UFRA anualmente que 
deverá ser objeto de análise, sem prejuízo das informações complementares que serão extraídas dos demais sistemas estruturantes do Governo Federal.

Quadro 17: Análise da evolução das despesas por grupo e elemento de despesa DESPESAS CORRENTES

\begin{tabular}{|c|c|c|c|c|c|}
\hline \multicolumn{6}{|c|}{ DESPESAS CORRENTES } \\
\hline Grupo de despesa & \multicolumn{5}{|c|}{ Despesa Liquidada $R \$$} \\
\hline 1. Pessoal & 2017 & $\mathrm{AH}$ & 2016 & $\mathrm{AH}$ & 2015 \\
\hline $\begin{array}{l}\text { Vencimentos/Vantagens } \\
\text { fixas pessoal civil }\end{array}$ & $107.137 .988,73$ & $21 \%$ & $88.331 .420,62$ & $8 \%$ & $81.949 .334,27$ \\
\hline $\begin{array}{l}\text { Aposentadoria, reserva } \\
\text { remunerada e reformas }\end{array}$ & 25.766.141,97 & $23 \%$ & $20.871 .824,39$ & $7 \%$ & $19.573 .037,70$ \\
\hline Demais elementos & $33.235 .269,15$ & $20 \%$ & $27.653 .888,87$ & $11 \%$ & $24.984 .095,26$ \\
\hline \multicolumn{6}{|l|}{$\begin{array}{l}\text { 3. Outras Despesas } \\
\text { Correntes }\end{array}$} \\
\hline $\begin{array}{l}\text { Auxilio Financeiro a } \\
\text { Estudantes }\end{array}$ & $2.945 .005,94$ & $-9 \%$ & $3.253 .538,04$ & $57 \%$ & $2.070 .052,49$ \\
\hline $\begin{array}{l}\text { Locação de Mão-de- } \\
\text { obra }\end{array}$ & $13.164 .929,12$ & $-11 \%$ & $14.862 .251,43$ & $-12 \%$ & $16.962 .263,12$ \\
\hline $\begin{array}{l}\text { Serviços de Terceiros } \\
\text { Pessoa Jurídica }\end{array}$ & $15.174 .092,03$ & $99 \%$ & 7.614.120,11 & $13 \%$ & $6.736 .640,82$ \\
\hline Auxílio Alimentação & 0 & $100 \%$ & $4.472 .287,73$ & $30 \%$ & $3.446 .640,96$ \\
\hline $\begin{array}{l}\text { Despesas de Exercícios } \\
\text { Anteriores }\end{array}$ & $3.780 .357,73$ & & 0 & & 0,00 \\
\hline Demais elementos & $8.418 .700,65$ & $-21 \%$ & $10.614 .179,88$ & $54 \%$ & $6.877 .055,58$ \\
\hline \multicolumn{6}{|l|}{ DESPESAS DE CAPITAL } \\
\hline Grupo de despesa & \multicolumn{5}{|c|}{ Despesa Liquidada $R \$$} \\
\hline 4. Investimentos & 2017 & $\mathrm{AH}$ & 2016 & $\mathrm{AH}$ & 2015 \\
\hline $\begin{array}{l}\text { Equipamentos e } \\
\text { Material Permanente }\end{array}$ & $1.634 .938,22$ & $151 \%$ & $652.597,16$ & $100 \%$ & 0,00 \\
\hline Demais elementos & $143.010,07$ & $-36 \%$ & $223.297,05$ & $-84 \%$ & $1.406 .617,57$ \\
\hline
\end{tabular}

Fonte: Elaboração própria a partir de Universidade Federal Rural da Amazônia (2017a; 2017b).

Mediante um cenário que demonstra que as despesas com pessoal cresceu a um quociente superior a $20 \%$, excedendo a casa dos cem milhões anuais, e o consequente aumento das despesas correntes necessárias à manutenção da Universidade, é possível mencionar que o crescimento da UFRA sob o aspecto orçamentário trouxe um pouco mais de complexidade à missão de analisar custos. Entretanto, algumas medidas já foram tomadas pela Secretaria do Tesouro Nacional para facilitar o procedimento de alimentação de dados. Em 2018, tornou-se obrigatório o preenchimento dos "Centros de Custos" no SIAFI no momento da liquidação da despesa, onde são informados: Mês, Ano, Unidade Gestora beneficiada, código do SIORG e Natureza de Despesa Detalhada, conforme 
orientação trazida através de Mensagem Siafi $^{8} N^{\circ} 2018 / 0508904$ constante no Anexo A da presente dissertação.

Ao detalhar essas despesas é possível, por exemplo, fazer comparações entre as formas de contratação de serviços. No exemplo da Tabela 2 extraem-se informações relacionadas aos gastos com combustíveis e manutenção, que demonstram estabilidade entre os valores gastos por ano na casa de Um milhão e meio. Apesar dessa pequena variação entre os anos, não há que se descartar a necessidade de buscar a redução desses valores através de medidas administrativas internas ou estudar alternativas de contratação que proporcionem custos mais baixos relativos aos serviços de transporte.

Tabela 2: Gastos com combustível e manutenção de veículos

\begin{tabular}{|c|c|c|c|}
\hline Ano & Combustível & Manutenção & Total \\
\hline $\mathbf{2 0 1 6}$ & $\mathrm{R} \$ 835.386,68$ & $\mathrm{R} \$ 660.686,13$ & $\mathrm{R} \$ 1.496 .072,81$ \\
\hline $\mathbf{2 0 1 7}$ & $\mathrm{R} \$ 875.468,43$ & $\mathrm{R} \$ 593.468,10$ & $\mathrm{R} \$ 1.468 .936,53$ \\
\hline Comparação & $+5 \%$ & $-10 \%$ & $-2 \%$ \\
\hline
\end{tabular}

Fonte: Adaptado de Universidade Federal Rural da Amazônia (2017a; 2017b).

A UFRA (Universidade Federal Rural da Amazônia, 2017a) relata que sua frota de veículos está à disposição para deslocamento de docentes e discentes às áreas rurais para desenvolvimento das atividades curriculares. Pelo fato de atuar principalmente na área de Ciências Agrárias em Belém, Castanhal, Igarapé-Açu, Capanema, Paragominas, Parauapebas, Salinópolis, Capitão-Poço e Tomé-açu, existem grandes demandas de viagens para realização de aulas práticas e pesquisas de campo. Também existem demandas relacionadas às atividades administrativas da instituição como transportes de documentos, materiais, bens e pessoal para manutenção.

No Relatório de Gestão do exercício de 2016 a UFRA informa que não possui um plano de substituição da frota, em face ao tempo de uso dos veículos. Quanto à possibilidade de substituição da aquisição de veículos pela locação, argumenta-se que a UFRA depende de repasse de verbas do Governo Federal e que seria inviável financeiramente pelo aumento dos gastos de custeio provocado pela terceirização integral do serviço de transporte. Entretanto, não foi realizado um estudo

\footnotetext{
${ }^{8}$ As Mensagens SIAFI (Comunica) são instrumentos de comunicação utilizados entre as Unidades Gestoras que utilizam o SIAFI. Através delas são recebidas as orientações dos órgãos superiores e comunicações oficiais, assim como possibilita a comunicação direta entre todos os órgãos da esfera federal.
} 
comparativo consistente baseado na análise de custos que permita decidir qual alternativa é a mais vantajosa economicamente para a UFRA.

Além do exemplo mencionado, esse tipo de comparação pode ser realizado para a maioria dos serviços que são contratados, obtendo cotações de diversas empresas e buscando as alternativas de serviços substitutos, e assim tomar as decisões de contratação baseadas em fontes confiáveis e relatórios embasados.

\subsection{Melhores práticas de utilização do sistema de informação de custos no Brasil}

Com o intuito de balizar os procedimentos de implantação da sistemática de Custos na UFRA sob a ótica da NBC T 16.11 (CONSELHO FEDERAL DE CONTABILIDADE, 2012), buscou-se no Brasil experiências exitosas de órgãos públicos que de forma estratégica e consistente concluíram a implantação da gestão sistêmica de custos.

Nesse sentido, apresentam-se as experiências do Banco Central do Brasil BACEN e da Empresa Brasileira de Comunicação - EBC. A experiência do BACEN considerada como pioneira no Brasil serviu, inclusive, como uma das bases dos estudos prévios do Sistema de Custos do Governo Federal. A experiência exitosa da EBC foi premiada com o Prêmio CHICO RIBEIRO sobre Contabilidade, Informação de Custos e Qualidade do Gasto no Setor Público no ano de 2017, na categoria "relato de experiências de implantação e uso da informação de custos".

Quanto aos métodos de custeio adotados pelos dois órgãos, no Bacen o método $A B C$ foi considerado como 0 mais adequado às necessidades reais $e$ peculiaridades daquele órgão, utilizando para tanto os Direcionadores de Custos para realizar o rateio dos seus recursos às atividades desenvolvidas e aos objetos de custeio previamente definidos.

A EBC adotou o método de custeio por Absorção, de forma que, a partir do modelo sugerido pela STN para criação do Custo Personalizado realizou as adaptações pertinentes e passou a utilizar de forma integrada os códigos de Plano Interno (PI - dados orçamentários) e de Centros de Custos. Essa integração permite que a EBC obtenha dados de custos vinculados à execução orçamentária e planejamento através dos objetos de custos que deseja mensurar. 
Ambas as experiências são reconhecidas nacionalmente, servindo de base para vários estudos acadêmicos e, principalmente, como modelos de implementação da sistemática de custos em órgãos da administração pública. A ideia de apresentar de forma resumida o histórico da implementação nesses dois órgãos se justifica, além do êxito alcançado, pelos métodos de custeio utilizados, e, também, pelas semelhanças existentes entre as estruturas organizacionais. Dessa forma, no processo de implementação da UFRA não haverá necessidade de acessar o conteúdo originário das experiências, posto que, aponta-se neste trabalho o que há de mais relevantes em cada experiência.

4.2.1 A experiência de implantação de um Sistema de Custos no Banco Central do Brasil - Método $A B C^{9}$

No Banco Central do Brasil, autarquia da administração pública indireta vinculada ao Ministério da Fazenda, a experiência de implantação do Sistema de Custos e Informações Gerenciais partiu da percepção de que a maioria dos órgãos públicos brasileiros ainda não praticava a sistemática de apuração dos seus custos, tampouco utilizando o método $\mathrm{ABC}^{10}$

A autarquia relata que entre os anos de 2002 e 2003 desenvolveu e implantou um Sistema de Custos e Informações Gerenciais que foi concebido como um instrumento de apoio à gestão, que permite a apuração, o detalhamento e a análise dos custos dos serviços, atividades, processos e macroprocessos de cada célula da sua estrutura organizacional.

Os esforços de um grupo de trabalho formado por servidores das áreas afins, juntamente com uma empresa de consultoria com profissionais experientes, foram importantes para iniciar a identificação dos processos de negócios, agrupados por macroatividades e posteriormente definir os macroprocessos funcionais. A definição dos seus objetos de custos (produto) fez com que os processos de trabalho dos departamentos e macroatividades tivessem seus custos direcionados aos macroprocessos finalísticos.

\footnotetext{
9 Apresentado a partir do trabalho da equipe de Consultoria de Custos e Informações Gerenciais do Departamento de Planejamento e Orçamento do Banco Central do Brasil (2004), denominado "O Sistema de Custos do Banco Central do Brasil - Um Estudo do Caso".

${ }^{10}$ A escolha do método pelo grupo de trabalho designado para dar subsídios à implantação foi baseada em participações em seminários e visitas em órgãos públicos e empresas privadas que haviam implantado o método $A B C$, além de visitas em consultorias com experiência comprovada e com demonstrações dos resultados alcançados. Todas as análises levaram à conclusão que este método era o mais adequado ao BACEN.
} 
Após a conclusão dos levantamentos das necessidades do Banco e das suas especificações, foi feita a contratação de um consórcio formado por duas empresas selecionado mediante concorrência internacional encarregada pelo desenvolvimento e implantação do Sistema de Custos. Uma empresa ficou responsável pelo desenvolvimento da solução tecnológica do Sistema e outra pelo desenvolvimento do modelo conceitual a ser aplicado.

O método de custeio $A B C$ foi adotado pelo Banco Central em seu modelo de custos, em razão do tratamento refinado que dá aos custos indiretos. A metodologia trouxe três dimensões principais: os recursos, as atividades e os objetos de custos. A partir disso foram estabelecidos os direcionadores de custos de recursos para atividades e de atividades para objetos de custos, para assim obter o custo dos objetos de custos, conforme fluxograma a seguir:

Figura 9: Sistemática de obtenção do custo dos objetos de custos

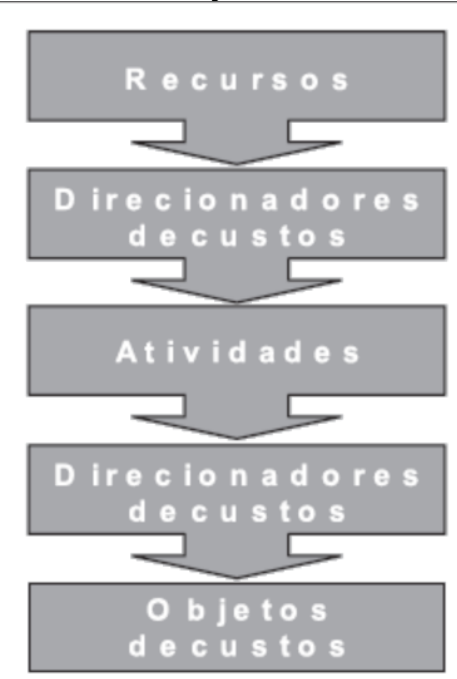

Fonte: Banco Central do Brasil (2004, p. 14).

O Módulo de Recursos recebe as informações dos sistemas internos, como o de recursos humanos, orçamento, materiais de consumo e de contabilidade. Essas informações são recebidas em níveis de agregação diferenciados, por representação regional, departamento ou subunidade. Neste módulo existe um grupo que recebe os recursos que precisam de apropriações até que estejam em nível de subunidade e assim destinados às atividades. Possui também outro grupo que engloba a estrutura hierárquica organizacional e recebem recursos de diversas origens e sistemas para que possam ser trabalhados e estarem em nível de subunidade. Como exemplo, as contas de depreciação e gastos com imóveis a 
apropriar, que são despesas que tem seu custo distribuído para todas as unidades do Banco em função da área útil ocupada.

Os recursos foram definidos partindo-se do Plano de Contas, indicando os agrupamentos contábeis separados por unidade administrativa. O maior item de recursos consumidos pela Instituição são os gastos com pessoal. Por isso, utilizouse uma sistemática própria de apontamentos que consegue registrar o percentual de esforço despendido por todos os servidores na execução de suas atividades para que esses custos sejam direcionados para as atividades desempenhadas. Esses apontamentos direcionam às atividades: os salários, encargos e benefícios do servidor, a depreciação dos equipamentos de informática por eles utilizados, materiais de consumo utilizados, espaço físico ocupado, entre outros custos.

Os apontamentos de horas é uma particularidade do modelo de custos do BACEN e é um critério confiável de distribuição dos custos para as atividades, pois utiliza informações fornecidas diretamente pelos servidores.

Merece destaque outra especificidade do Sistema de Custos do BACEN que é a adoção da premissa de não-existência de ociosidade na utilização dos recursos. Significa que todos os recursos custeados no Sistema são consumidos por atividades. A adoção desse pressuposto se dá pela dificuldade, em um primeiro momento, de identificar mecanismos de controle objetivos que auxiliem na aferição das ociosidades, se existirem.

Quadro 18: Resumo dos principais grupos de recursos identificados pelo Sistema BACEN Despesas gerais - água e esgoto, serviços de comunicação, materiais, serviços gráficos, cópias e reproduções de documentos, aquisição de periódicos, etc.

Despesas com imóveis - Depreciação e gastos com imóveis-área comum, depreciação e gastos com imóveis-área útil, manutenção de instalações prediais, energia elétrica, reformas, etc.

Despesas com móveis, utensílios e equipamentos - Depreciação de móveis e utensílios e demais itens.

Despesas com pessoal - Salários, encargos e benefícios.

Despesas com serviços de terceiros - Contratos de prestação de serviços das mais variadas naturezas, compreendendo as diversas áreas do BACEN.

Despesas com o meio circulante - Segurança predial, manutenção predial, manutenção de equipamentos, movimentação interna de numerários, fretamento de aeronaves, processamento automatizado de cédulas etc.

Fonte: Elaboração própria baseada em Banco Central do Brasil (2004, p. 19) 
Quanto ao Módulo de Atividades foram adotados dois grupos, o primeiro que engloba despesas específicas de objetos de custos que não são exatamente atividades, em razão da premissa de que os objetos de custos só receberiam recursos de atividades. O segundo grupo contempla atividades identificadas em cada unidade da estrutura hierárquica cujos custos serão direcionados aos objetos de custos. Portanto, o módulo de recurso indica os valores de custos às atividades através de direcionadores. Depois disso, as atividades têm seus custos direcionados aos objetos de custos adequados.

As atividades foram levantadas a partir de entrevistas com todos os chefes das unidades e subunidades. Aproveitou-se essa oportunidade para identificar os processos que seriam definidos como as principais funções dessas unidades administrativas ou os objetos de custos de nível 4, com o intuito de mensurar seus custos. Assim, as atividades foram agrupadas e relacionadas aos respectivos objetos de custos. Foram mapeadas 3.488 atividades, das quais 890 atividades únicas, ou seja, sem considerar as repetições de atividades em mais de uma subunidade, pois o BACEN possui atividades que são desenvolvidas por várias unidades, como exemplo, as atividades de apoio logístico, de secretariado e de controle de pessoal, existentes em todas as unidades.

Demonstra-se na figura 10 o detalhamento do fluxo de agregação de custos no modelo adotado pelo BaCen do nível de menor agregação para o maior.

Figura 10: Fluxo de agregação de custos adotado pelo BaCen

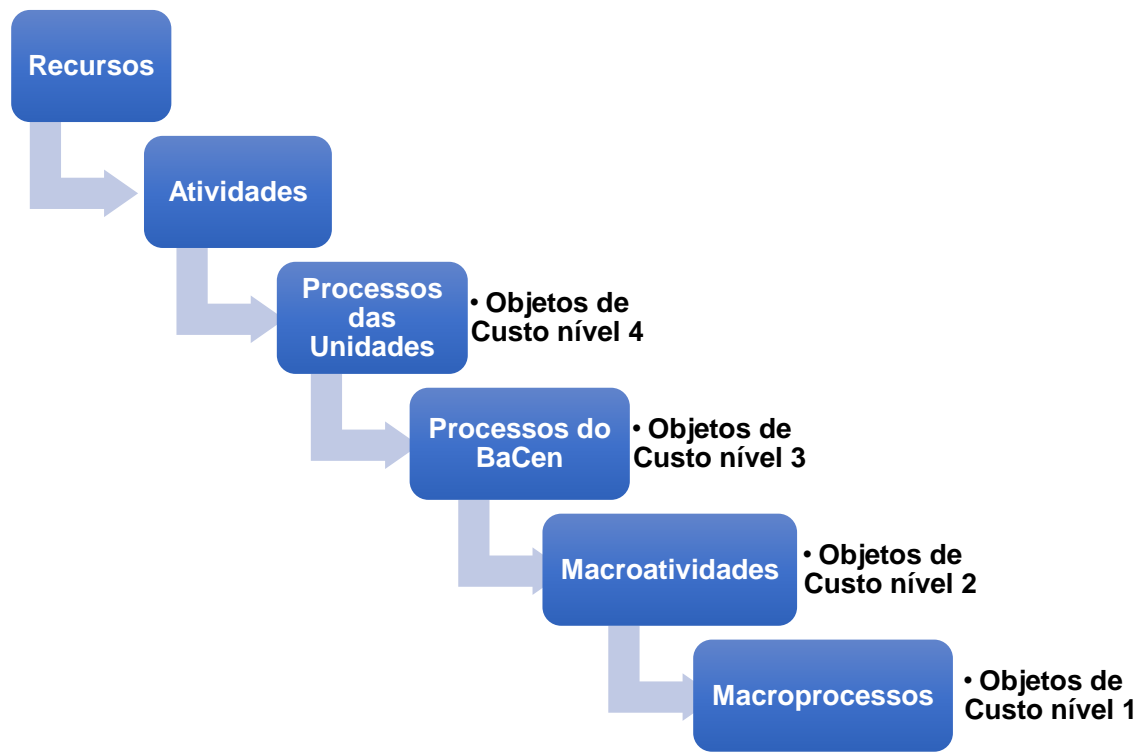

Fonte: Elaboração própria baseada em Banco Central do Brasil (2004, p. 19) 
O Módulo de Objetos de Custos contém quatro níveis de estrutura para evidenciar a realidade dos processos desempenhados pelas unidades administrativas. Definiu como objeto de custos de uma unidade os serviços ou produtos finais resultantes de todas suas atividades.

Figura 11: Os quatro níveis dos objetos de custos do BACEN

\begin{tabular}{|c|c|c|c|c|}
\hline & $\begin{array}{l}\text { Processos } \\
\text { unidades }\end{array}$ & $\begin{array}{l}\text { Processos } \\
\text { Bacen }\end{array}$ & Macroatividades & Macroprocessos \\
\hline Atividades & $\begin{array}{l}\text { Objetos de } \\
\text { custos nível } 4\end{array}$ & $\begin{array}{l}\text { Objetos de } \\
\text { custos nível } 3\end{array}$ & $\begin{array}{l}\text { Objetos de } \\
\text { custos nível } 2\end{array}$ & $\begin{array}{l}\text { Objetos de } \\
\text { custos nível } 1\end{array}$ \\
\hline
\end{tabular}

Fonte: Banco Central do Brasil (2004 p. 16)

O quarto nível é o mais desagregado recebendo os custos das atividades desenvolvidas pelas unidades. Os objetos do terceiro nível podem receber custos do quarto nível e de atividades que lhe são relacionadas, podendo ocorrer também nos demais níveis. Os objetos de custos do primeiro nível são os que possuem maior agregação e representam os macroprocessos do BaCen. Os objetos de custo de nível 1 são os produtos finais das ações, chamados macroprocessos institucionais.

Foram definidos pelo BaCen três macroprocessos institucionais: Formulação e gestão das políticas monetária e cambial, Regulação e supervisão do Sistema Financeiro Nacional (SFN) e Administração do Sistema de Pagamentos Brasileiro (SPB) e do meio circulante. Esses objetos de custos de nível 1 foram desmembrados da seguinte forma, nos objetos de custos de nível 2 e 3 :

Quadro 19: Formulação e gestão das políticas monetária e cambial

\begin{tabular}{|c|c|c|}
\hline Objeto custo nível 1 & Objeto custo nível 2 & Objeto custo nível 3 \\
\hline \multirow{10}{*}{$\begin{array}{l}\text { Formulação e gestão } \\
\text { das políticas } \\
\text { monetária e cambial }\end{array}$} & \multirow{3}{*}{$\begin{array}{c}\text { Administração da política } \\
\text { monetária }\end{array}$} & Operação com títulos \\
\hline & & Controle da política monetária \\
\hline & & Divulgação da política monetária \\
\hline & \multirow{3}{*}{$\begin{array}{c}\text { Administração da política } \\
\text { cambial }\end{array}$} & Regulamentação da política cambial \\
\hline & & Controle da política cambial \\
\hline & & Divulgação da política cambial \\
\hline & \multirow[b]{2}{*}{$\begin{array}{c}\text { Administração das reservas } \\
\text { internacionais }\end{array}$} & Aplicação das reservas internacionais \\
\hline & & $\begin{array}{c}\text { Divulgação das reservas } \\
\text { internacionais }\end{array}$ \\
\hline & $\begin{array}{l}\text { Administração do passivo } \\
\text { externo do governo central }\end{array}$ & \\
\hline & Relações internacionais & \\
\hline
\end{tabular}

Fonte: Banco Central do Brasil (2004, p. 21). 
Quadro 20: Regulação e supervisão do Sistema Financeiro Nacional (SFN)

\begin{tabular}{|c|c|c|}
\hline Objeto custo nível 1 & Objeto custo nível 2 & Objeto custo nível 3 \\
\hline \multirow{4}{*}{$\begin{array}{c}\text { Regulamentação e } \\
\text { supervisão do SFN }\end{array}$} & Regulamentação & Fundamentação \\
\cline { 2 - 3 } & Supervisão & Regulamentação \\
\cline { 2 - 3 } & & Processos administrativos \\
\cline { 2 - 3 } & Reestruturação do sistema \\
& financeiro estatal & Regime especial \\
\cline { 2 - 3 } & & \\
\hline
\end{tabular}

Fonte: Banco Central do Brasil (2004, p. 22)

Quadro 21: Administração do Sistema de Pagamentos Brasileiro (SPB) e do meio circulante

\begin{tabular}{|c|c|l|}
\hline Objeto custo nível 1 & Objeto custo nível 2 & \multicolumn{1}{|c|}{ Objeto custo nível 3 } \\
\hline $\begin{array}{c}\text { Administração do } \\
\text { Sistema de Pagamentos }\end{array}$ & Administração do SPB & $\begin{array}{l}\text { Estabelecimento de diretrizes para o } \\
\text { SPB }\end{array}$ \\
\cline { 2 - 3 } $\begin{array}{c}\text { Brasileiro (SPB) e do } \\
\text { meio circulante }\end{array}$ & $\begin{array}{c}\text { Administração do meio } \\
\text { circulante }\end{array}$ & $\begin{array}{l}\text { Provimento da demandiação do SPB } \\
\text { pelo produto cédula moeda }\end{array}$ \\
\cline { 3 - 3 } & & $\begin{array}{l}\text { Saneamento do meio circulante } \\
\text { Regulamentação e controle do meio } \\
\text { circulante }\end{array}$ \\
\hline
\end{tabular}

Fonte: Banco Central do Brasil (2004, p. 22)

Adicionalmente aos macroprocessos do Banco, foram criados mais cinco objetos de custos de nível 1: Atendimento ao Tesouro Nacional, Administração de fundos e programas, Institucional, Aposentadoria e Afastados. São tratados de maneira separada para que não se confundam com os macroprocessos principais, pois é necessário para a Instituição que se conheça o quanto é gasto com cada um desses elementos.

Os objetos de custos só recebem custos dos recursos se foram efetivamente consumidos por eles, ou seja, se foi possível identificar e medir o nível de contribuição de cada um deles. Aqueles recursos e as atividades que não foram relacionados de forma adequada aos macroprocessos do Banco, ou cujo consumo não pôde ser medido, são totalizados no objeto de custos denominado Institucional. Também são direcionados a este objeto de custo os recursos ou as atividades cujo dispêndio advém do atendimento de necessidades corporativas, gerando benefícios a todos os macroprocessos.

Destaca-se o fato de as unidades administrativas da área-fim do Banco realizarem, também, atividades características de suporte, que são trabalhos 
administrativos necessários ao seu funcionamento. Entretanto, seus custos são apropriados aos objetos de custos ligados ao principal objetivo da existência da unidade.

Foi observado na classificação das despesas que não há um padrão linear no fluxo dos custos a partir das atividades até os objetos de custos de nível 1. Na prática, uma atividade pode estar relacionada aos objetos de custos de nível 4, porém, pode ir direto ao nível 2 por não ter relação com o nível 3, conforme cada caso e sua realidade operacional.

Essas peculiaridades relacionadas ao tratamento dos objetos de custos merecem destaque por ser um dos pontos mais delicados relacionados ao levantamento de custos. Por essa razão, enfatizou-se a forma de tratamento dos três direcionadores de custos, chamados pelo BaCen como: de primeiro estágio, de segundo estágio e entre objetos de custos.

Os direcionadores de custos de primeiro estágio referem-se aos critérios escolhidos pelo BaCen para apropriar os custos de um recurso para diferentes atividades. São direcionadores de custos de recursos para outros recursos e de recursos para atividades.

Os direcionadores de custos de segundo estágio são os critérios para direcionar os custos de atividades para os objetos de custos. Apropria os recursos das atividades para o primeiro objeto de custos ao qual se relaciona.

Quanto aos direcionadores de custos entre objetos de custos foram estabelecidos quatro níveis de objetos de custos onde os direcionadores de custos fariam a classificação entre os diferentes níveis de objetos de custos.

Os direcionadores mencionados estão dispostos de forma resumida no quadro 22. São os direcionadores essenciais para a adoção do método $A B C$ no Bacen, pois necessita de níveis maiores de detalhes para identificar com maior precisão os custos de todas as atividades desenvolvidas. Essa metodologia pode ser adotada não somente pelas instituições públicas, como também nas instituições privadas, podendo obter resultados semelhantes, se não, melhores. 
Quadro 22: Direcionadores de Custos do Banco Central

\begin{tabular}{|c|c|c|}
\hline \multirow{5}{*}{$\begin{array}{l}\text { Direcionadores } \\
\text { de custos de } \\
\text { primeiro } \\
\text { estágio - } \\
\text { Recursos para } \\
\text { atividades }\end{array}$} & $\begin{array}{l}\text { Metros } \\
\text { quadrados } \\
\text { por unidade, } \\
\text { por praça e } \\
\text { por edifício }\end{array}$ & $\begin{array}{l}\text { Apropria os custos de contas de depreciação e outros gastos com o } \\
\text { uso de bens imóveis a cada uma das unidades do Banco, } \\
\text { proporcionalmente à área total utilizada. No âmbito da unidade, o } \\
\text { valor é apropriado às subunidades em função } \\
\text { do quantitativo de servidores. }\end{array}$ \\
\hline & $\begin{array}{l}\text { Apontamento } \\
\text { de horas }\end{array}$ & $\begin{array}{l}\text { Apropria os custos dos recursos às atividades, proporcionalmente ao } \\
\text { percentual do esforço despendido pelos servidores de uma } \\
\text { subunidade na realização de suas atividades. Apropria recursos } \\
\text { como: salários, encargos e benefícios, materiais, hardware, } \\
\text { depreciação de móveis e imóveis, estagiários, etc., a cada uma das } \\
\text { atividades do Banco. }\end{array}$ \\
\hline & $\begin{array}{l}\text { Número de } \\
\text { servidores } \\
\text { por } \\
\text { subunidade }\end{array}$ & $\begin{array}{l}\text { Faz apropriação intermediária dos custos de determinados recursos } \\
\text { para outros recursos, em função da quantidade de servidores } \\
\text { lotados por subunidade, tais como: despesas com água e esgoto, } \\
\text { depreciação de hardware e de equipamentos de uso pessoal, } \\
\text { materiais de expediente. A apropriação é feita proporcionalmente ao } \\
\text { número de servidores de cada uma das subunidades do Banco. }\end{array}$ \\
\hline & $\begin{array}{l}\text { Quantidade } \\
\text { de } \\
\text { estagiários e } \\
\text { mensageiros } \\
\text { por unidade }\end{array}$ & $\begin{array}{l}\text { Apropria os custos de um recurso a outros recursos, com base na } \\
\text { quantidade de estagiários existentes na unidade. }\end{array}$ \\
\hline & $\begin{array}{l}\text { Apropriação } \\
\text { direta de } \\
\text { recursos }\end{array}$ & $\begin{array}{l}\text { Apropriação do total dos custos de um recurso a uma atividade } \\
\text { específica. A apropriação direta de recursos ocorre pela existência } \\
\text { das despesas específicas e de alocação não definida, sendo } \\
\text { direcionadas integralmente para objetos de custos específicos, } \\
\text { passando antes pelas atividades que recebem a mesma } \\
\text { denominação. }\end{array}$ \\
\hline \multirow{3}{*}{$\begin{array}{l}\text { Direcionadores } \\
\text { de custos de } \\
\text { segundo } \\
\text { estágio- } \\
\text { Atividades } \\
\text { para Objetos } \\
\text { de Custos }\end{array}$} & $\begin{array}{l}\text { Apropriação } \\
\text { direta de } \\
\text { atividades }\end{array}$ & $\begin{array}{l}\text { Apropria de forma direta a totalidade dos custos de uma atividade a } \\
\text { determinado objeto de custo. }\end{array}$ \\
\hline & $\begin{array}{l}\text { Apontamento } \\
\text { de horas }\end{array}$ & $\begin{array}{l}\text { Apropria os custos de uma atividade a mais de um objeto de custos, } \\
\text { conforme o percentual do esforço que tenha sido despendido pelos } \\
\text { servidores do Banco, oportunidade em que é apontado para quais } \\
\text { objetos de custos uma determinada atividade foi desempenhada. }\end{array}$ \\
\hline & $\begin{array}{l}\text { Apropriação } \\
\text { igualmente } \\
\text { distribuída }\end{array}$ & $\begin{array}{l}\text { Apropria o custo de uma atividade para os objetos de custos, em } \\
\text { função da quantidade desses objetos, ou seja, na mesma proporção } \\
\text { do número de destinações. Dos direcionadores de segundo estágio } \\
\text { utilizados pelo Sistema, a apropriação direta é responsável pelo } \\
\text { direcionamento de } 98 \% \text { das atividades. }\end{array}$ \\
\hline \multirow{4}{*}{$\begin{array}{l}\text { Direcionadores } \\
\text { de custos } \\
\text { entre objetos } \\
\text { de custos }\end{array}$} & $\begin{array}{l}\text { Apropriação } \\
\text { direta }\end{array}$ & $\begin{array}{l}\text { Apropria de forma direta a totalidade dos custos de um objeto de } \\
\text { custos a outro determinado objeto de custos. A apropriação é o } \\
\text { direcionamento mais utilizado pelo modelo. }\end{array}$ \\
\hline & $\begin{array}{l}\text { Apropriação } \\
\text { igualmente } \\
\text { distribuída }\end{array}$ & $\begin{array}{l}\text { Apropria igualmente o custo de um objeto de custos para dois ou } \\
\text { mais objetos de custos em função do número de objetos de custos } \\
\text { de destino. }\end{array}$ \\
\hline & $\begin{array}{l}\text { Número de } \\
\text { servidores } \\
\text { por } \\
\text { subunidade }\end{array}$ & $\begin{array}{l}\text { Distribui o custo de um determinado objeto de custos para outros } \\
\text { objetos de custos proporcionalmente ao número de servidores em } \\
\text { cada subunidade. }\end{array}$ \\
\hline & $\begin{array}{l}\text { Número de } \\
\text { servidores } \\
\text { por unidade }\end{array}$ & $\begin{array}{l}\text { Distribui o custo de um determinado objeto de custos para outros } \\
\text { objetos de custos proporcionalmente ao número de servidores } \\
\text { (pessoal) existentes em cada unidade objeto de apuração. }\end{array}$ \\
\hline
\end{tabular}

Fonte: Banco Central do Brasil (2004, p. 24-28). 
O sistema para o cálculo dos dados de custos no BaCen, o Oros Analytics, é uma ferramenta utilizada em escala mundial, especializada no método $A B C$. $O$ sistema recebe informações dos módulos que são alimentados pelos servidores. Posteriormente, os dados ficam disponíveis aos gestores do Banco para atender suas necessidades informacionais relativas a custos.

As características do sistema do BaCen são semelhantes à utilizada atualmente pelo Sistema de Informações de Custos do Governo Federal, principalmente quanto à tecnologia Data Warehouse, que disponibiliza relatórios personalizados, além de várias ferramentas que auxiliam os gestores na obtenção das informações relativas a Recursos, Atividades, custo médio de atividades de apoio, custos com viagens, custos com servidores ativos, inativos e afastados, etc.

O sistema permite ainda, que se obtenha informações da execução dos orçamentos, resultados das operações típicas, comparação do custo das atividades de apoio e das atividades finalísticas, comparação dos custos das atividades semelhantes desempenhadas por unidades distintas, comparar custos de atividades desempenhadas pelo banco com o valor dos produtos/serviços ofertados externamente, além de poder apurar custos gerais para estabelecimento de taxas de administração a serem cobradas.

Para que houvesse êxito na implementação do sistema foram necessárias estratégias relacionadas à divulgação e treinamento. Um importante trabalho prévio foi feito para sensibilização dos diretores e chefes de unidades compreendendo todas as áreas e unidades da instituição, alcançando um nível satisfatório de aceitação. Foram realizados seminários e treinamentos específicos sobre o sistema e sobre o andamento da implementação, além de disponibilizarem todo o tipo de material necessário para consultas de fácil acesso aos colaboradores.

O curto prazo para a implantação de um projeto com esse alcance em uma organização complexa e de grande porte como o BaCen provocou algumas inconsistências relativas ao levantamento das atividades, à definição dos direcionadores de custos e à identificação dos objetos de custos. A equipe gestora precisou tomar algumas medidas para redirecionar gastos então alocados indevidamente em outros objetos de custos, após o término da implantação do projeto. 
Algumas dificuldades foram encontradas para a definição, o desenvolvimento e a implantação desse projeto pela inexistência de experiências com características e abrangência similares ao modelo implantado no BaCen.

Foi percebida uma restrição natural quanto à utilização plena do Sistema pela dificuldade de vincular os resultados de custos ao desempenho institucional que se almejava. Essa vinculação repercutiria no modelo de avaliação individual e de equipes, e assim propiciaria maior utilização do Sistema de Custos por parte dos servidores.

$\mathrm{Na}$ etapa de levantamento das atividades das unidades, houve um detalhamento excessivo das atividades, dificultando o tratamento gerencial das informações. Para isso, foi analisado posteriormente que era necessário mais tempo na elaboração do dicionário de atividades. Entretanto, o objetivo principal foi alcançado, que era tornar suficientemente claros os objetivos do Sistema de Custos.

Não foram apontados no relato da experiência do BaCen os detalhes e especificidades relativas à escolha do sistema, manutenção, desafio da contratação e etc., pois o intuito principal dessa demonstração é buscas as práticas exitosas adotadas no decorrer da implantação que podem ser utilizadas na utilização do SIC na UFRA, tendo em vista que o sistema já está disponibilizado de forma gratuita, sendo necessário somente solicitar autorização de acesso ao servidor do órgão responsável pela habilitação de usuários.

Destaques do relato da Experiência do Bacen:

Considerando a complexidade do método de custeio $A B C$, destaca-se a adoção de uma sistemática própria de apontamentos, que registra o percentual de esforço de todos os servidores na execução de suas atividades direcionando os custos às atividades desempenhadas.

> O Bacen também adota um critério de distribuição dos custos para as atividades através do apontamentos de horas, utilizando informações fornecidas pelos próprios servidores.

> O Bacen adota a premissa de não-existência de ociosidade na utilização dos recursos. Assim, não existirá recurso contabilizado que não será consumido por alguma atividade. Essa escolha se dá pela 
impossibilidade, no momento, de aferir de forma objetiva as ociosidades que porventura existam.

O sistema adotado permite realizar comparações, sejam dos custos das atividades de apoio e das atividades finalísticas, dos custos das atividades semelhantes desempenhadas por unidades distintas, dos custos de atividades desempenhadas pelo banco com o valor dos produtos/serviços ofertados externamente, e apurar custos para estabelecer taxas de administração a serem cobradas.

$>$ Foi criada uma unidade permanente para promover o desenvolvimento, implantação e continuidade de utilização dos sistemas de custos pelas equipes internas de maneira que se dediquem exclusivamente ao projeto, para que não ocorra permanentemente uma dependência técnica de terceiros.

$>$ O Bacen promoveu treinamentos adequados e de forma prévia para a equipe nos programas e ferramentas a serem utilizados, pois considerou que o aprendizado dos instrumentos de forma concomitante à implantação do projeto poderia gerar atrasos e retrabalho.

$>$ Preocupado com o desconforto natural que o aumento no controle das operações poderia causar aos seus colaboradores e evitar possíveis resistências, o Bacen buscou de forma permanente manter a comunicação relativa à implantação de projeto de sistema de custos ao longo das etapas de concepção, desenvolvimento e implantação.

Foram estabelecidos metas e parâmetros internos de custos para balizar a aferição do desempenho dos diversos processos organizacionais do Bacen, além de prever a captação de referenciais externos que possam permitir comparações (benchmarks). 
4.2.2 A experiência da implantação da sistematização de custos na Empresa Brasileira de Comunicação S/A - Método Absorção ${ }^{11}$

Visando fomentar a utilização da informação de custos como um instrumento de governança no setor público a EBC dedicou-se à implantação do projeto denominado "sistematização de custos". Esse projeto buscou proporcionar informações de fácil acesso, disponibilizadas por meio de links interativos e dinâmicos, gerados por meio de ferramenta de business intelligence - BI, com dados obtidos diariamente do SIAFI e SIAPE, e por meio da extração de dados do Sistema de Informação de Custos - SIC.

O diferencial do modelo implementado pela EBC e que o faz inovador é a proposta de integrar custos a planejamento orçamentário, por meio de uma codificação com elementos comuns, chamada de "elo". A premissa foi otimizar os sistemas estruturantes e ferramentas já disponíveis, cujas licenças fossem gratuitas.

Até que fosse alcançado o patamar atual em relação à apuração de custos, a EBC relata que as informações de custos eram apuradas através de processos morosos, ineficientes e complexos, quase sempre levantando dados de forma manual. Ainda assim, a análise dos dados levantados não produziam informações relevantes que pudessem auxiliar a tomada de decisão pelos gestores.

A EBC passou então a analisar metodologias de apuração de custos aplicadas em outros órgãos públicos, além do benchmarking efetuado em diversas empresas públicas e na Secretaria do Tesouro Nacional, para que se pudessem iniciar os procedimentos de implantação do Sistema de Informação de Custos.

No ano de 2016, após reformulação da equipe de custos e utilização das novas ferramentas tecnológicas, como o Tesouro Gerencial e o SIC, pôde-se realizar a implantação da Sistematização de Informação de Custos sob um novo olhar sistêmico e organizacional. Para alcançar o êxito nos objetivos propostos foi necessário o envolvimento de integrantes das áreas de planejamento e execução orçamentária, de custos e contabilidade. A STN foi convidada a palestrar sobre o tema e dirimir as dúvidas da equipe técnica quanto aos dados de custos no SIAFI e os impactos nos registros contábeis. Foi apresentado pela STN um fluxo ideal para a

\footnotetext{
${ }^{11}$ Apresentado a partir do artigo denominado "Sistematização de Custos no Setor Público com uso de ferramentas de $\mathrm{BI}$ - Business Intelligence - Um Relato de Experiência da Implantação de Custos na Empresa Brasil de Comunicação S/A - EBC" do ano de 2017, elaborado pelos servidores da EBC: Ênio Alves de Souza, Carolina Soares Bernardes, Antônio Martins de Araújo Filho, Milton Vilarouca Neto e Rubem Sérgio Silva Rosa (SOUZA et al., 2017).
} 
personalização de custos pelo órgão, composto por quatro etapas (planejamento, estruturação, implementação e gestão) para nortear o processo de implantação, conforme figura 12.

Figura 12: Quatro etapas do Custo Personalizado

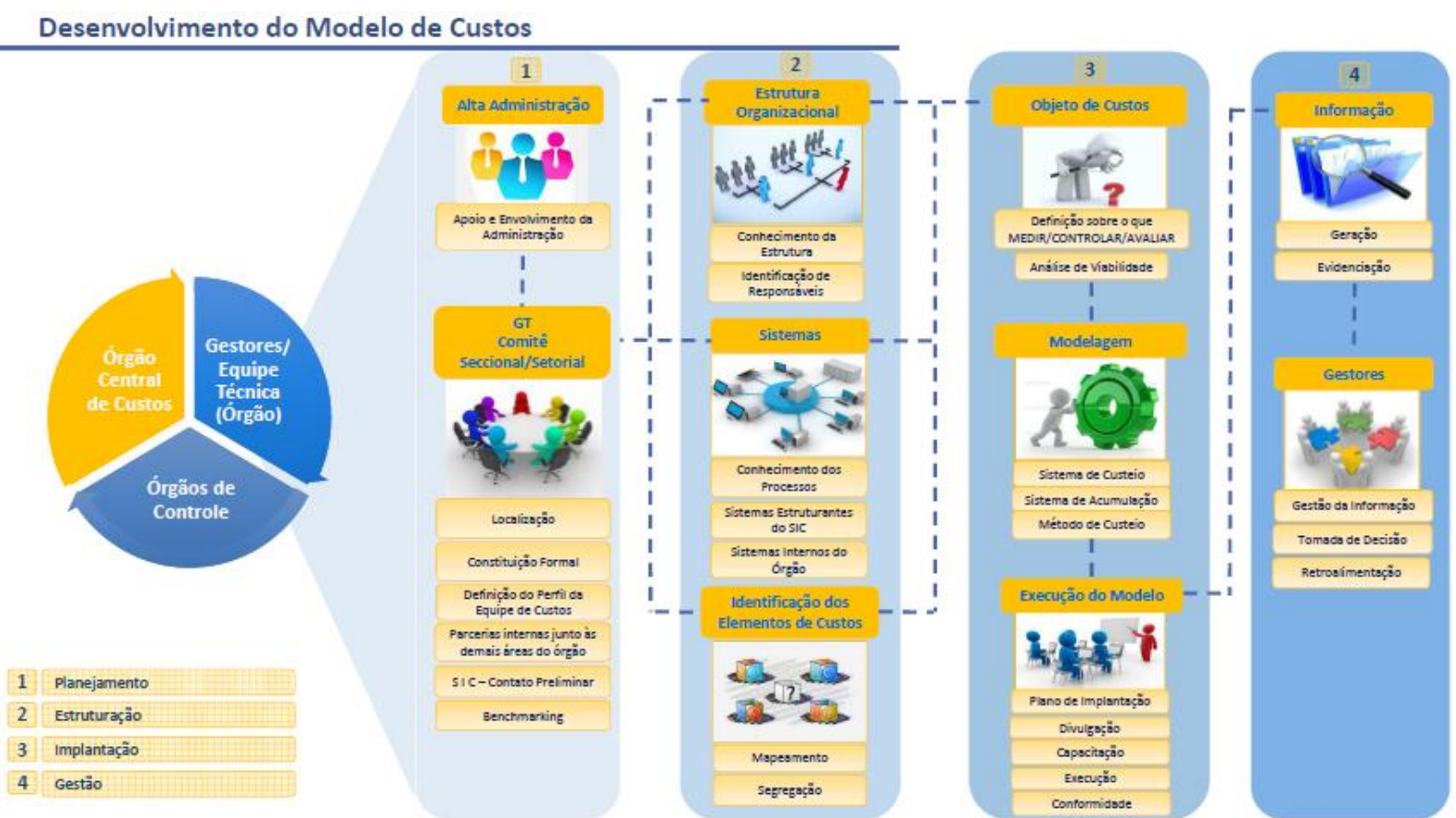

Fonte: Brasil. Secretaria do Tesouro Nacional (2018, p.192).

A partir do modelo sugerido pela STN, a equipe de custos da EBC, apoiada pela Alta Administração, fez as adaptações necessárias ao que já possuíam em relação aos procedimentos de custos:

1) Constituição da Coordenação de Custos, possuindo uma equipe técnica específica para essa finalidade;

2) Alinhamentos das informações de custos com as áreas de gestão de pessoas, contabilidade, auditoria, almoxarifado, planejamento orçamentário e execução orçamentária, obtendo apoio dessas áreas:

3) Capacitação da equipe na ferramenta Tesouro Gerencial e no Sistema de Informação de Custos (SIC) por meio de cursos ministrados na Escola de Administração Fazendária (ESAF); e

4) Participação em seminários e encontros de custos no setor público. 
Para cumprimento da segunda etapa proposta pela STN, relacionada à estruturação, a EBC criou um mapa de um projeto onde foram apontadas as justificativas, os efeitos, os resultados a alcançar, os principais recursos, as partes interessadas, os requisitos, as principais entregas, um cronograma gerencial, as premissas, as restrições e os riscos do projeto de sistematização das informações de custos. Esse projeto foi então incorporado aos projetos estratégicos da EBC, dentro de uma linha de "Modernização da Administração", sendo assim considerado um projeto de alta relevância.

Os custos são apurados na EBC utilizando-se o método por absorção, levantando seus custos com base nos gastos destinados aos produtos e serviços oferecidos. A metodologia proposta utiliza o Plano Interno (PI) de forma conjunta com o Centro de Custos que é alimentado no SIAFI, para fazer uma ponte entre custos e planejamento orçamentário. O PI é um componente opcional na estrutura orçamentária que pode ser usado para detalhar um projeto ou atividade do órgão e demonstrar a dinâmica gerencial da unidade.

Essa metodologia indica os dados de custos de forma integrada às informações orçamentárias e de planejamento, sob a visão dos centros de custos (plataformas/produtos/serviços) e sob a visão organizacional (diretorias/áreas) de forma sistêmica. A integração ocorre através de uma codificação que agrega os objetos de custos que a EBC se propôs a mensurar.

A premissa dessa metodologia é a integração de elementos comuns apontados no código do PI no ato da emissão da Nota de Empenho (NE), e no Código de Custos, apontado no ato da liquidação da despesa no SIAFI. Essa integração veio obedecer a orientações da NBC T 16.11 (CONSELHO FEDERAL DE CONTABILIDADE, 2012), de que o SICSP deve estar integrado com o processo de planejamento e orçamento, que estejam sob a mesma base conceitual, e se refiram aos mesmos objetos de custos, para permitir o controle entre o orçado e o executado. A figura 13 demonstra a codificação utilizada na metodologia de apuração de custos da EBC, contendo os 11 caracteres, tanto para os PI's quanto para os Centros de Custos, nas quais o objeto do gasto é o elemento de integração entre orçamento e custos. 
Figura 13: Codificação do Planejamento Orçamentário e de Custos

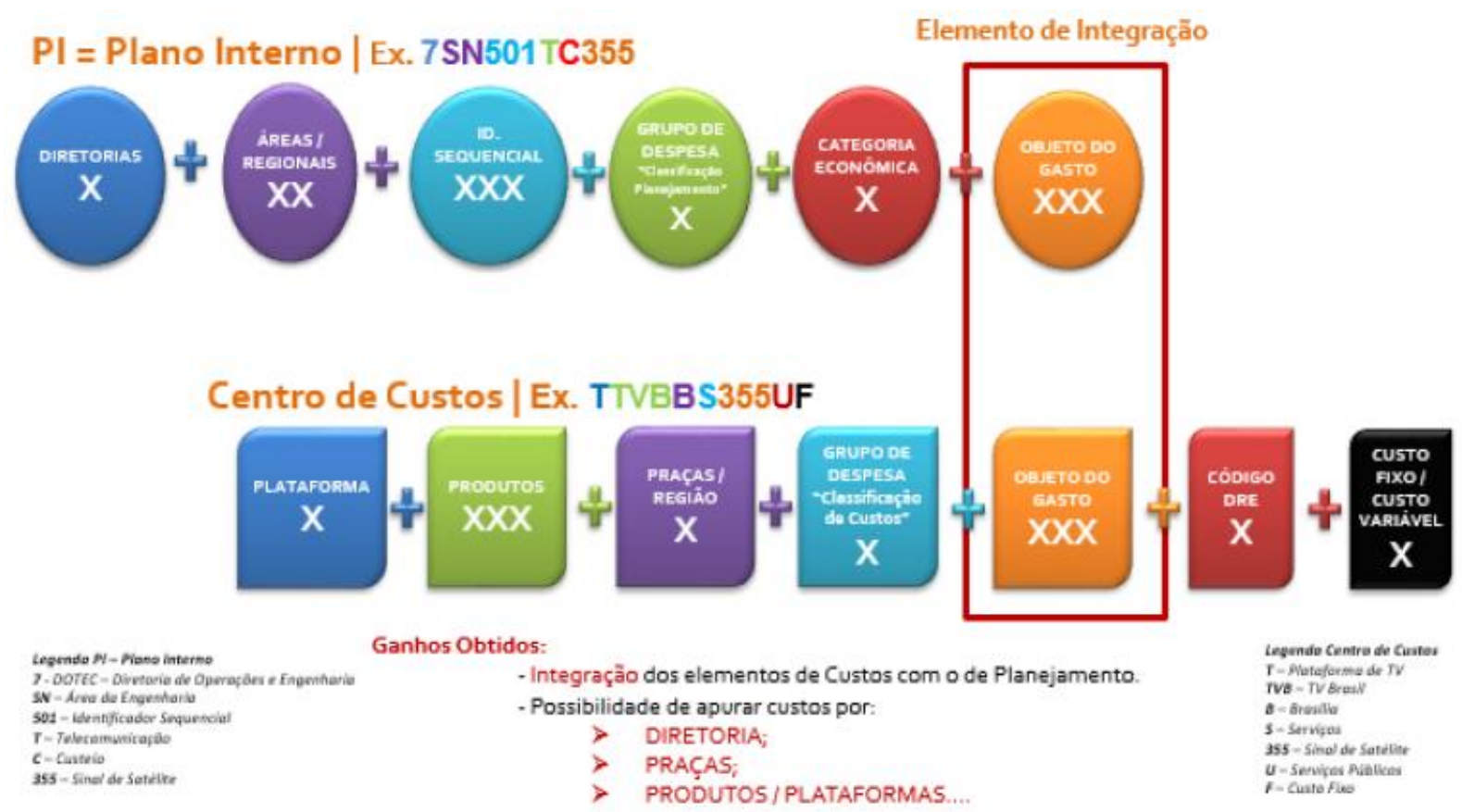

Fonte: Souza et al. (2017, p. 13)

As informações do PI retratam as transações orçamentárias identificadas por diretorias, áreas, sequencial de planejamento, grupo de natureza da despesa, categoria econômica e objeto do gasto, que são o desmembramento das contas de natureza de despesas. Esta combinação de dados permite uma visão da EBC sob o aspecto organizacional e sob o aspecto econômico conforme demonstrado na figura 14, o que facilita, sobremaneira, a geração de informação sistêmica e qualificada.

Figura 14: Codificação do Planejamento Orçamentário

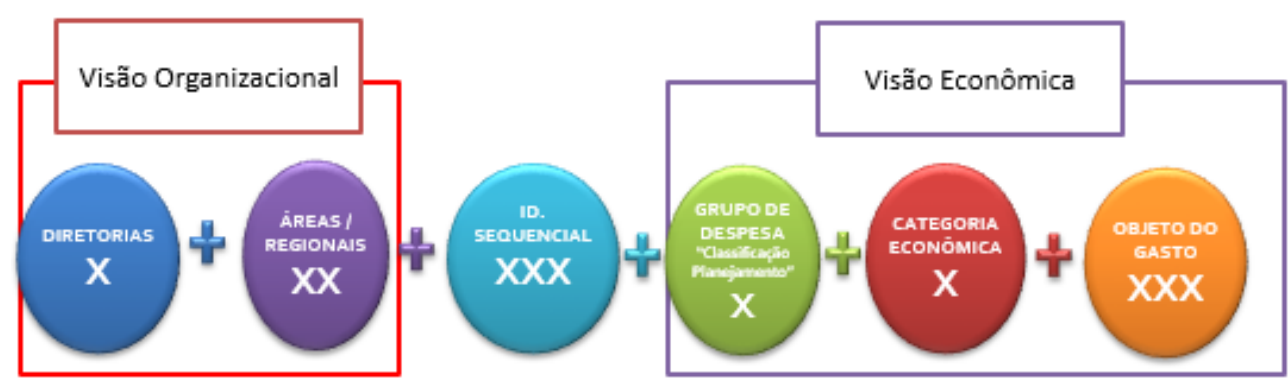

PI = Plano Interno | Ex. 7 SN 501 T C 355

Fonte: Souza et al. (2017, p. 14)

$\mathrm{Na}$ visão organizacional, os custos são apresentados por diretorias e por áreas, podendo o gestor fazer o acompanhamento dos gastos e, inclusive, fazer análises comparativas por período. 
A visão econômica demonstra a agregação dos custos por grupo de natureza da despesa, por categoria econômica, se custeio ou investimento, e por objeto do gasto.

A partir da união entre as informações orçamentárias e de custos é possível gerar gráficos, tabelas e outros demonstrativos que representam os custos organizacionais da EBC de um determinado período. Como exemplo, apresenta-se o Gráfico 1 que demonstra os reflexos dos custos por diretorias, e a Tabela 3 com os custos por área.

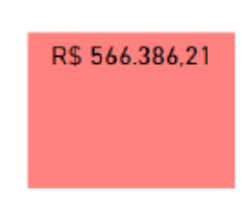

DIAF-DRETORIA DE ADMeNCTRACZ̈O FNANCAS E
$\mathrm{R} \$ 470.103 .19$

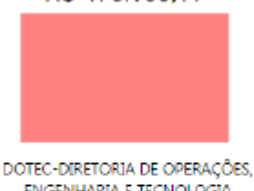

Gráfico 1: Custos por Diretorias

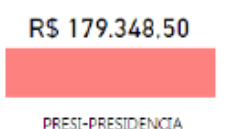

PREST-PRESIDENCTA

Fonte: Souza et al. $(2017$, p.15)

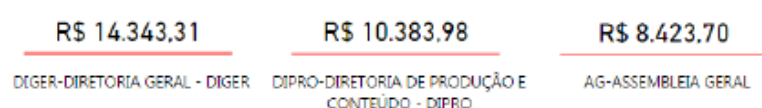

CONTEUDO - DAPRO

Tabela 3: Custos por Áreas

\begin{tabular}{|l|r|}
\hline AREAS & \multicolumn{2}{l|}{ CUSTOS } \\
\hline Administração E Logistica & R\$ $484.994,52$ \\
\hline Conselho Fiscal & RS $8.423,70$ \\
\hline Diretoria De Administração, Finanças E Pessoas - DIAFI & RS $69.514,81$ \\
\hline Diretoria De Produção E Conteúdo - DIPRO & RS $10.383,98$ \\
\hline Engenharia & R\$ $470.103,19$ \\
\hline Gestão De Pessoas & RS 9.886,04 \\
\hline Gex Marketing E Negócios & RS 5.835,00 \\
\hline Orçamento, Finanças E Contabilidade & R\$ $1.990,84$ \\
\hline Rede & RS 5.300,70 \\
\hline Total & RS 1.248.988,89 \\
\hline
\end{tabular}

Fonte: Souza et al. (2017, p.15)

A tabela de Centro de Custos possui 11 caracteres alfanuméricos, que permitem retratar as transações de custos conforme a necessidade dos gestores da EBC, por plataforma, por produtos, por praças ou regiões, por grupo de despesas, por objeto de gastos, por grupo de contas da Demonstração do Resultado do Exercício - DRE e por Custos Fixos ou Variáveis. Essas informações combinadas 
permitem que se obtenha uma visão dos custos sob os aspectos produtivo (produtos e serviços), econômico e contábil, conforme no Gráfico 2.

Gráfico 2: Visões da Codificação de Custos

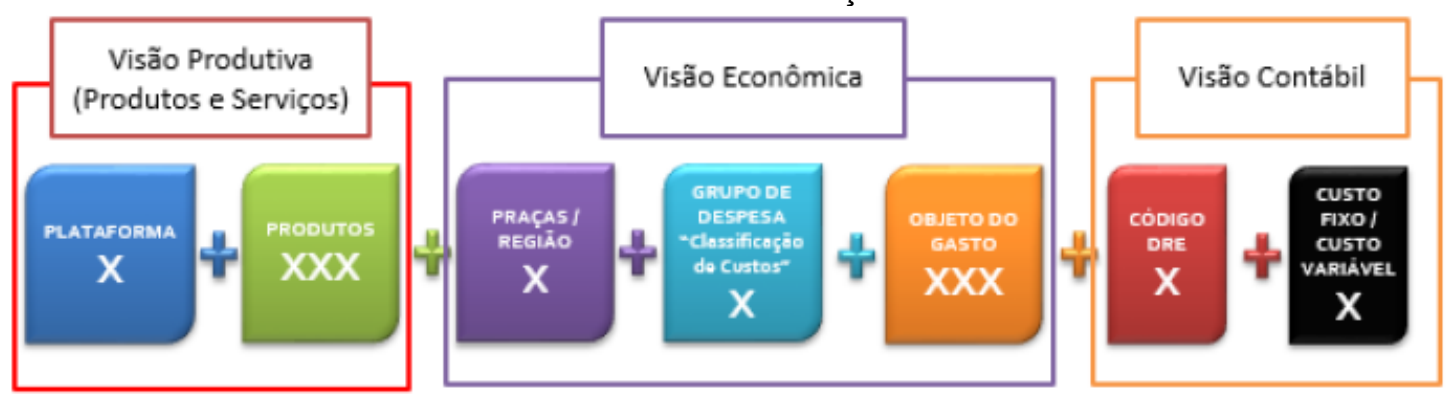

Centro de Custos | Ex. T TVB B S 355 U F

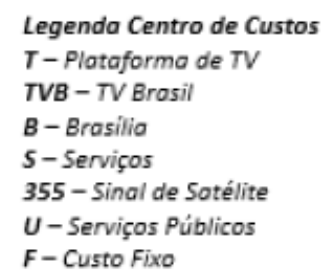

Fonte: Souza et al. (2017, p.16)

A visão produtiva retrata transações dos recursos destinados às plataformas e produtos ou serviços da EBC, e identifica todos os gastos ligados à sua atividade fim. É possível distinguir dessa maneira os custos atribuídos às TVs, Rádios, Portal WEB e Captação dos custos administrativos. As atividades e processos de produção da EBC de forma detalhada são três canais de televisão, sete rádios, prestação de serviços de publicidade legal, análise e monitoramento de mídia e serviços de radiodifusão.

A visão econômica da codificação de custos permite que se obtenha levantamento de custos por praças ou regiões, por grupo de despesas e por objeto do gasto. Os custos por praças ou regiões propicia aos gestores a evolução dos gastos nas diversas localidades de atuação da EBC, permitindo, através desse instrumento, a gestão sobre a viabilidade das operações em cada localidade. 0 Gráfico 3 apresenta o mapa de custos e os valores apurados por cada praça ou região. 
Gráfico 3: Mapa de custos por praça ou região de atuação da EBC
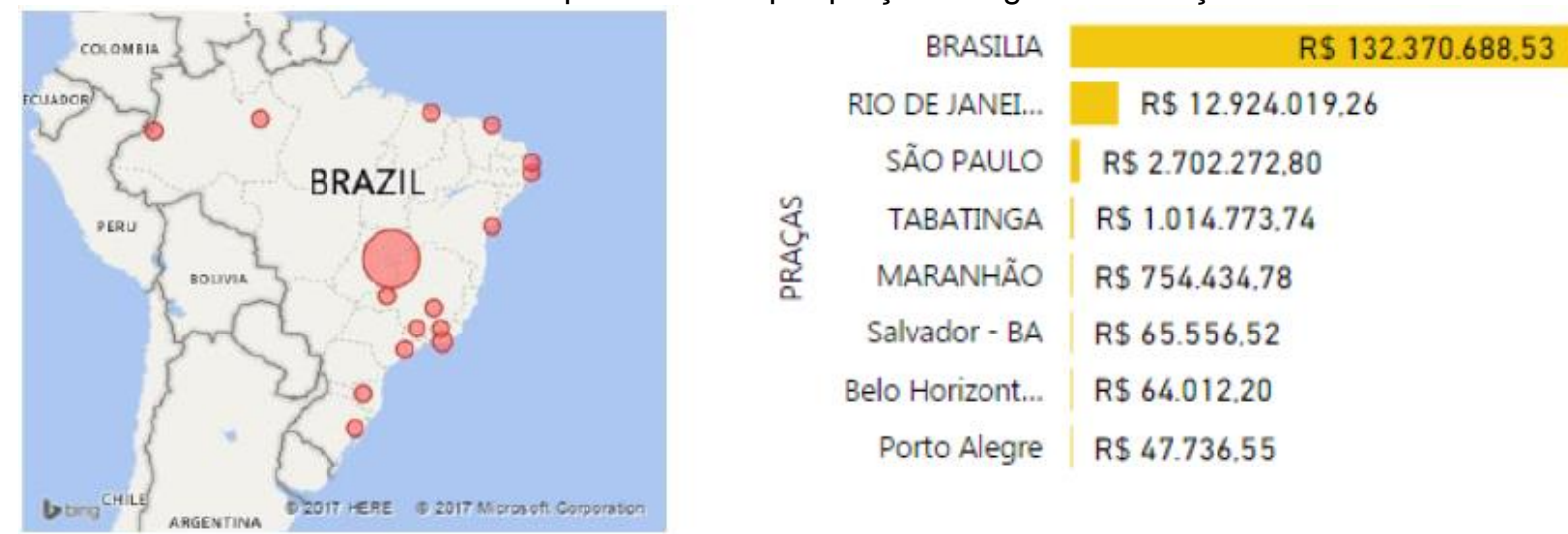

Fonte: Souza et al. (2017, p.18)

O levantamento de informações de custos por grupo de despesas permite agregar custos com pessoal, custos com serviços, custos com depreciação e custos com materiais. Dessa forma, o gestor pode visualizar rapidamente os recursos executados em cada grupo num determinado período, possibilitando projetar os gastos do exercício seguinte e segregar recursos oriundos do orçamento de pessoal e do orçamento de custeio.

Quanto ao detalhamento do objeto do gasto, permite que se visualizem os pormenores dos custos da EBC de forma personalizada. A EBC relata que a conta "Serviços de Telecomunicações" está disposta no menor nível de detalhamento possível no SIAFI em relação à classificação dos elementos de despesas. Entretanto, ao se desmembrar, através do objeto de gasto, esta conta em "Telefonia Móvel", "Telefonia Fixa" e "Sinal de Satélite", obteve-se um ganho extremamente relevante em qualidade da informação de custos, em razão do volume da conta "Sinal de Satélite" em relação às demais de telecomunicações, conforme a Tabela 4.

Tabela 4: Custos por objeto de gasto

\begin{tabular}{|c|c|c|c|}
\hline ELEMENTO DE DESPESA & OBJETO DO GASTO & $\boldsymbol{\nabla}$ & janeiro \\
\hline \multirow[t]{4}{*}{ SERVICOS DE TELECOMUNICACOES } & Telefonia Movel & & RS $32.272,20$ \\
\hline & Telefonia Fixa & & RS $26.969,18$ \\
\hline & Sinal De Satélite & & $\mathrm{R} \$ 1.067 .592,61$ \\
\hline & Total & & $\mathrm{R} \$ 1.126 .833,99$ \\
\hline
\end{tabular}

Fonte: Souza et al. (2017, p18.)

No tocante à visão contábil da codificação de custos, ela permite segregar os elementos que compõem o Custo dos Serviços Prestados - CSP, que faz parte da 
Demonstração do Resultado do Exercício - DRE e, também, permite segregar Custos Fixos dos Custos Variáveis.

Através dessa codificação a EBC pôde atender à NBC T 16.11 (CONSELHO FEDERAL DE CONTABILIDADE, 2012), item 25, que orienta que as informações de custos podem subsidiar a elaboração da Demonstração do Resultado Econômico (DRE), que tem por finalidade evidenciar o resultado econômico das ações do setor público.

A codificação de custos, utilizada nas transações contábeis, representa para a EBC um avanço significativo quanto ao tempo de obtenção da informação dos CSP. A Empresa relata que as tarefas feitas hoje em 30 minutos precisavam de cerca de três semanas para analisar e refinar os dados levados à DRE e comparar com os dados das planilhas eletrônicas e com dados extraídos do SIAFI Gerencial. Atualmente, a EBC obtém de forma sistêmica diariamente o valor total dos Custos dos Serviços Prestados, representando ganhos na tempestividade, qualidade e rastreabilidade das informações de custos.

Além desses benefícios, as informações sistêmicas sobre os custos das ações da EBC e os dados sobre os custos fixos e variáveis permitem que o gestor possa fazer análises de âmbito orçamentário quanto aos gastos do exercício seguinte, e assim, utilizar critérios técnicos para determinar cortes ou aumentos de gastos futuros.

No decorrer da presente pesquisa foram expostos os desafios para uma organização tratar os custos indiretos em virtude da complexidade de determinar bases de rateio ou direcionadores de custos. A NBC T 16.11 (CONSELHO FEDERAL DE CONTABILIDADE, 2012), item 15, orienta que as cotas de distribuição podem ser feitas por: área ocupada; dotação planejada disponível; volume ocupado em depósitos; quantidade de ordens de compra emitida para fornecedores; consumo de energia elétrica; número de servidores na unidade administrativa responsável, etc.

Com esse norte, a EBC adotou uma metodologia de apuração dos custos indiretos a partir da identificação dos custos intermediários, para serem, posteriormente, direcionados aos objetos de custos por um critério de rateio. 
Figura 15: Modelo de apuração dos custos indiretos da EBC

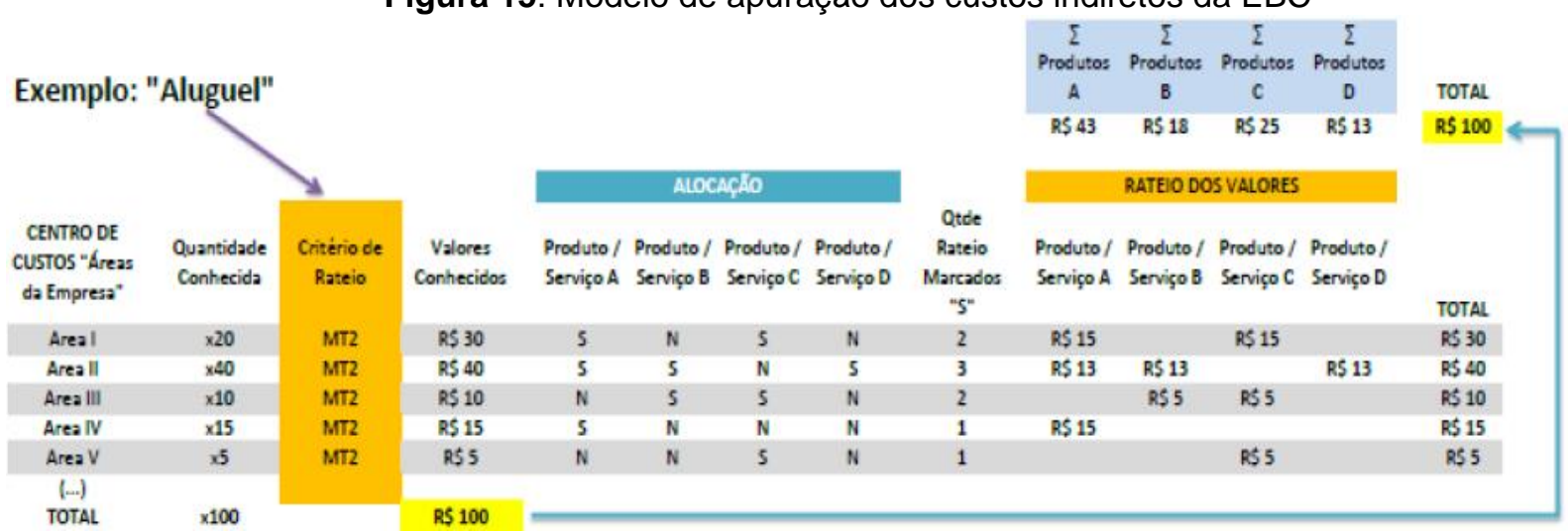

Fonte: Souza et al. (2017, p.20)

A figura 15 apresenta, como exemplo, o aluguel das instalações da EBC, cujo valor precisa ser rateado por todas as áreas. $O$ rateio foi realizado através do mapeamento da metragem das áreas (MT2) que estão diretamente envolvidas em cada produto/serviço. Posteriormente, fez-se a identificação dos produtos vinculados a cada área e, finalmente, realizaram-se os rateios dos valores para alocá-los aos produtos. Os valores acumulados dos produtos são o custo indireto daquele produto. Este procedimento pode ser aplicado à grande parte dos custos indiretos como condomínio, serviços de limpeza, serviços de vigilância, etc.

$O$ relato da EBC confirma que o trabalho mais intenso de constituição das bases de rateio ocorre na fase inicial de implantação. A partir dessa fase, os rateios que precisam ser realizados para os períodos seguintes são baseados em conformidade com as bases já estabelecidas.

A sistematização de custos implantada na EBC permitiu que fossem gerados relatórios gerenciais com informações para subsidiar os gestores nas tomadas de decisão. Primeiramente, foram elaborados modelos de relatórios com informações gerenciais por níveis ou camadas, distribuídas por plataforma e por diretoria, permitindo que o gestor possua várias perspectivas para realizar sua análise. $O$ passo seguinte foi utilizar a ferramenta de Business Intelligence MS-Power BI que consolida os dados oriundos da base dos sistemas estruturantes do Governo Federal e apresenta-os através de painéis de controle (dashboards), com informações tempestivas diariamente atualizadas.

A utilização do SIC para a elaboração dos relatórios para fins de custos só foi possível em janeiro de 2017, após a abertura da aba de "Centro de Custos" no SIAFI e a inserção do "Plano Interno" na emissão do empenho, possibilitando a geração da 
base de dados. Dessa forma, foi possível identificar os custos incorridos em um determinado período, utilizando a métrica detalhamento de custos - DetaCusto.

Para fazer a composição da base de dados de custos, a EBC, primeiramente, no ato da emissão do empenho, informa através do PI a codificação de planejamento orçamentário. No passo seguinte, no ato da liquidação da despesa, informa o código de custos na aba "Centro de Custos" do SIAFI.

A partir desses procedimentos, a EBC capta a informação de custos através da extração de dados no SIC e trabalha os dados em planilhas eletrônicas para que sejam dados os tratamentos relativos aos rateios.

Finalmente, após o tratamento do rateio dos dados, vincula-se a base de dados na ferramenta MS-Power BI para gerar os painéis de controle (dashboard's). A figura 16 resume os passos desse processo.

Figura 16: Extração dos Dados de Custos na EBC

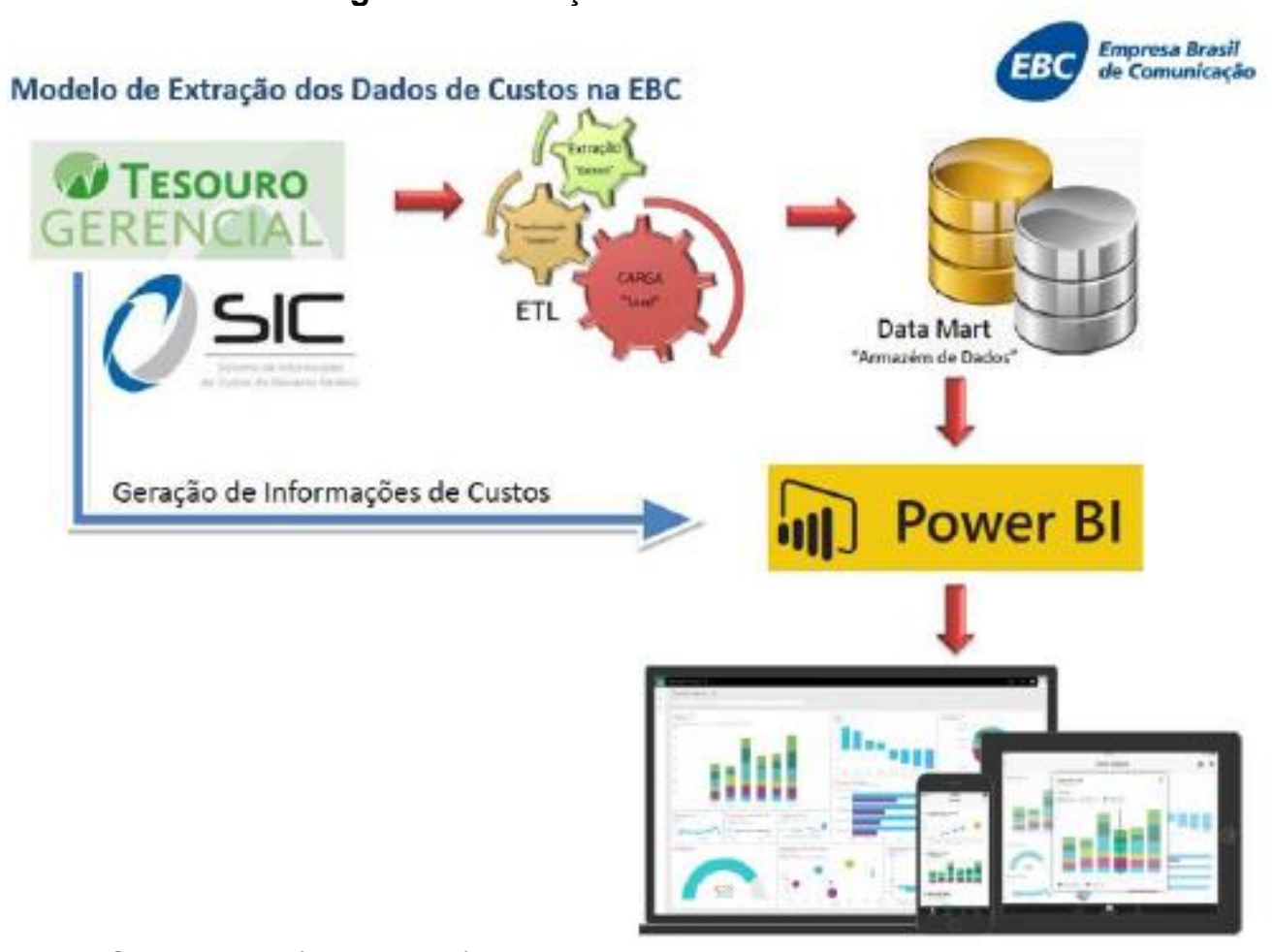

Fonte: Souza et al. $(2017$, p.23)

A EBC buscou capacitar seus empregados, de diversas áreas da empresa, para criarem os próprios dashboards conforme suas necessidades, além de se familiarizarem com a ferramenta. Assim, foram obtidos diversos painéis de controle, que retratam os custos alocados e segmentados por plataformas, produtos, objeto 
do gasto, custos fixos e variáveis, custos por praças, e o detalhamento dos custos selecionados, conforme demonstrado no Gráfico 4.

Gráfico 4: Painel de Custos

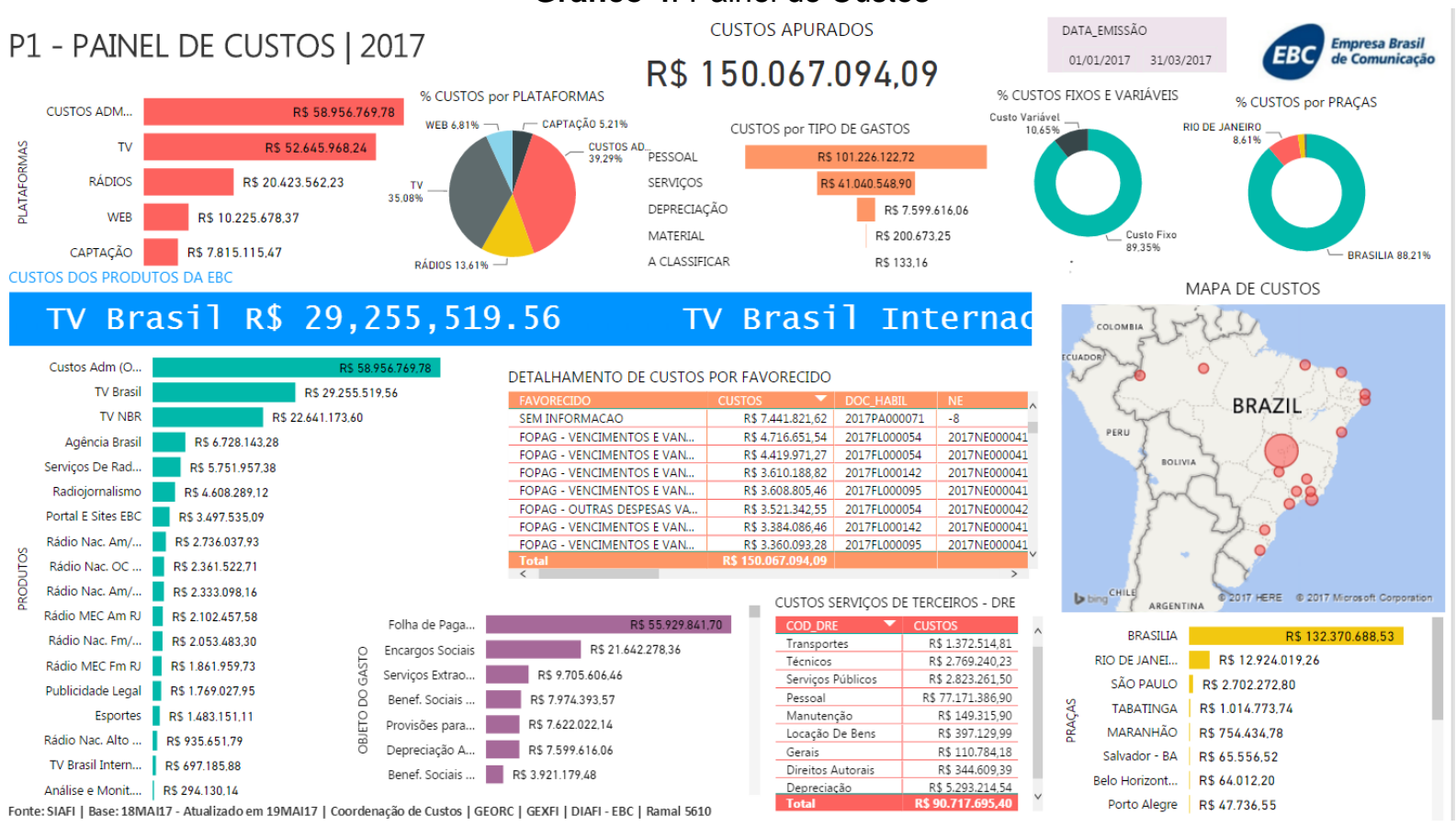

Fonte: Souza et al. (2017, p.24)

Gráfico 5: Painel Detalhamento dos Custos

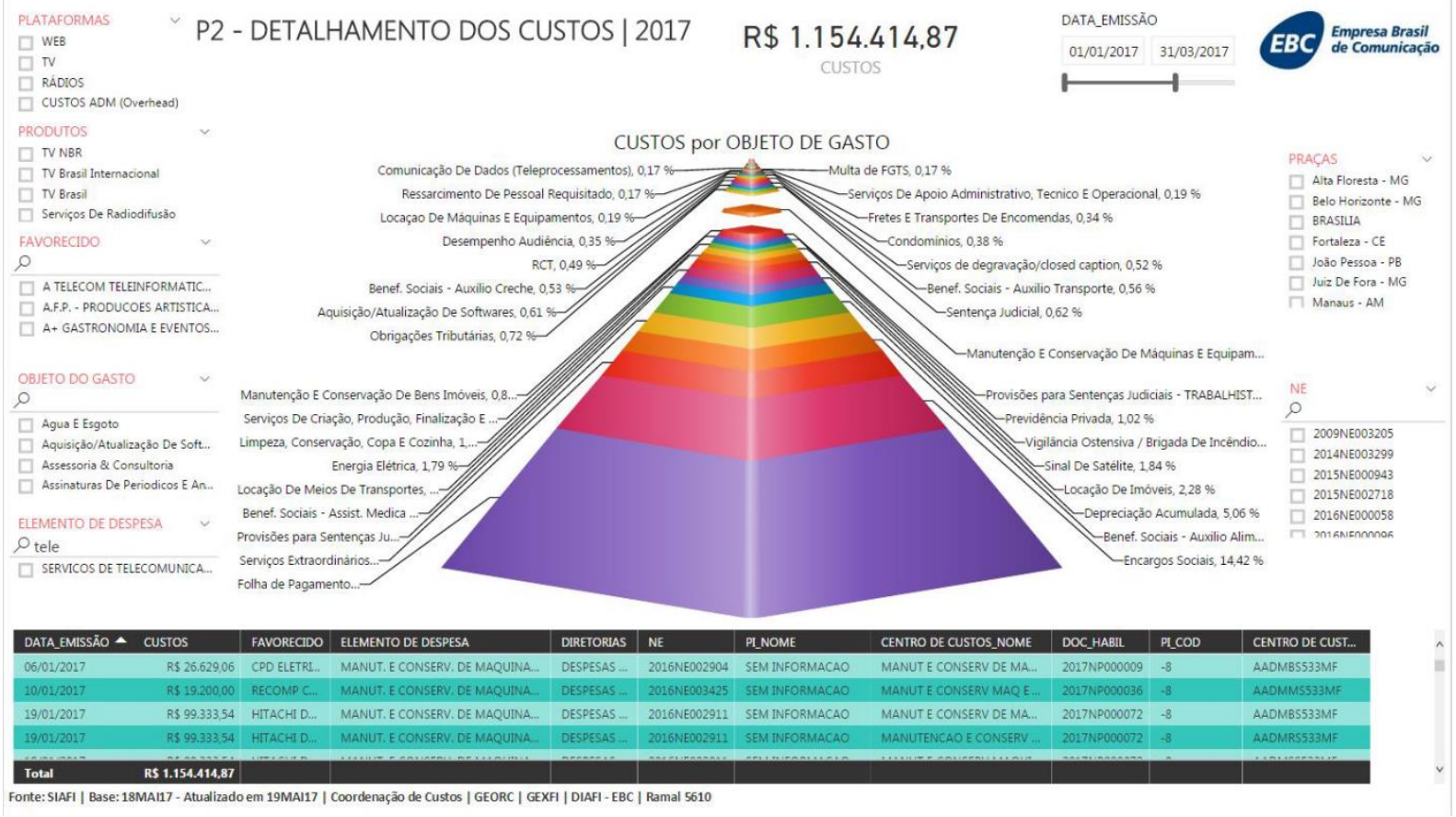

Fonte: Souza et al. (2017, p.25) 
O gráfico 5 representa um painel criado pela EBC no qual os custos são apresentados de maneira detalhada. O Painel de Custos apresenta os dados de custos da EBC de forma organizada e visualmente amigável, com informações intuitivas e interativas, para que o gestor, ao acessar o link (disponível em https://goo.gl/EoM1Qw), selecione partes do gráfico e aumente o nível de detalhes da informação selecionada. As informações do painel podem ser detalhadas por custos por produtos, por favorecido, por objeto de gasto, por elemento de despesas, por praças ou por notas de empenho, de forma individual ou combinada.

A EBC criou um painel de controle que demonstra as informações de custos do ponto de vista gerencial, para identificar os custos indiretos envolvidos nos produtos e serviços da EBC (overhead) e, também, do ponto de vista contábil, que possibilita obter os custos vinculados diretamente aos seus produtos e serviços, e serve de base para a identificação dos Custos dos Serviços Prestados, conforme método de absorção. Neste sentido, o painel demonstra esses dados sob a ótica dos custos totais, custos administrativos e custos operacionais, conforme o gráfico 6 .

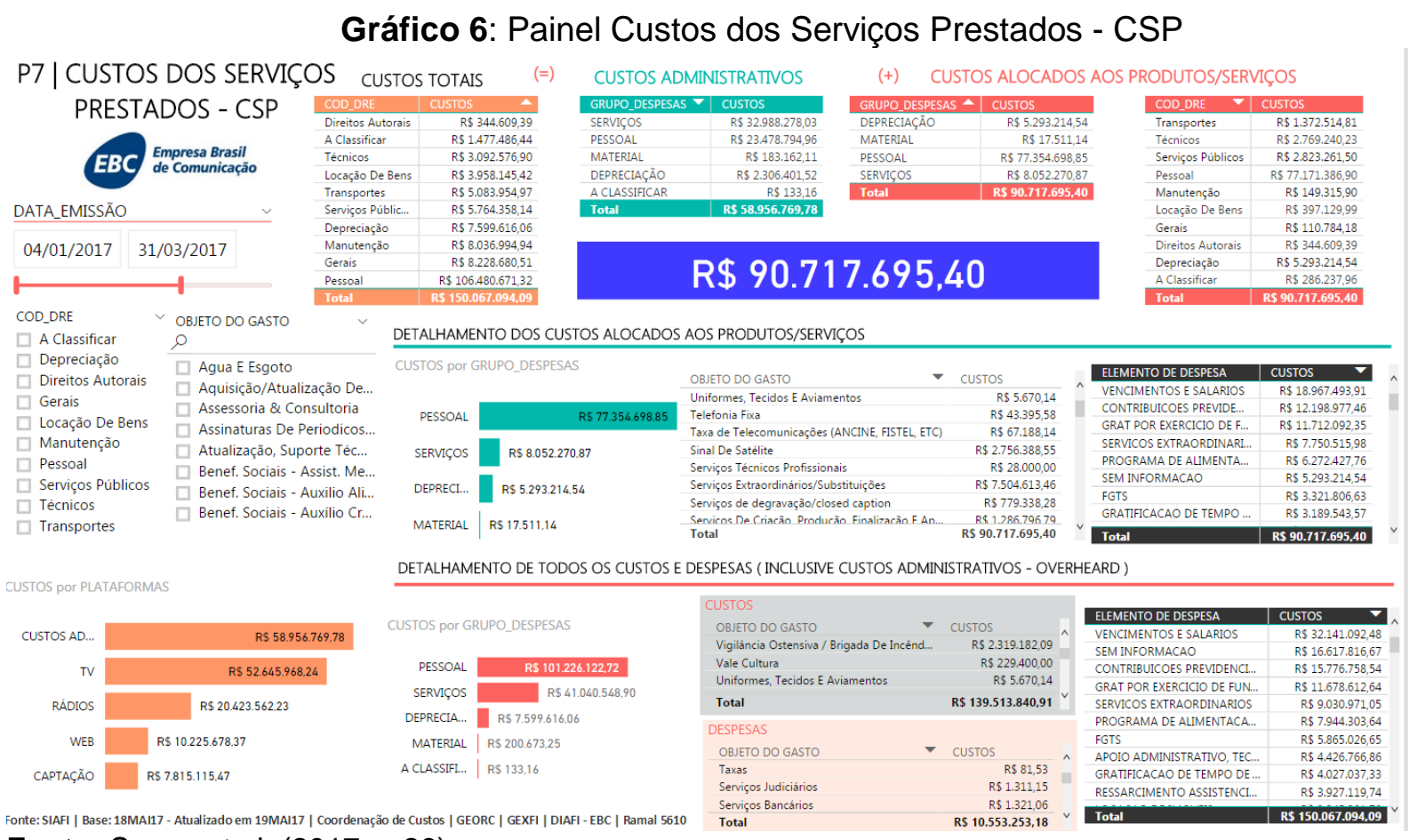

Fonte: Souza et al. (2017, p.26)

A EBC elaborou um painel de controle baseado nos custos operacionais, apontando os custos dos produtos e serviços segregados em Plataformas, Produtos e Grupo de Despesas. A importância desse painel é a possibilidade de retratar os 
custos operacionais dispendidos ao longo de um período e permitir a comparação com os resultados dos trimestres seguinte para fins de tomada de decisão, conforme gráfico 7.

Gráfico 7: Painel Custos Consolidados
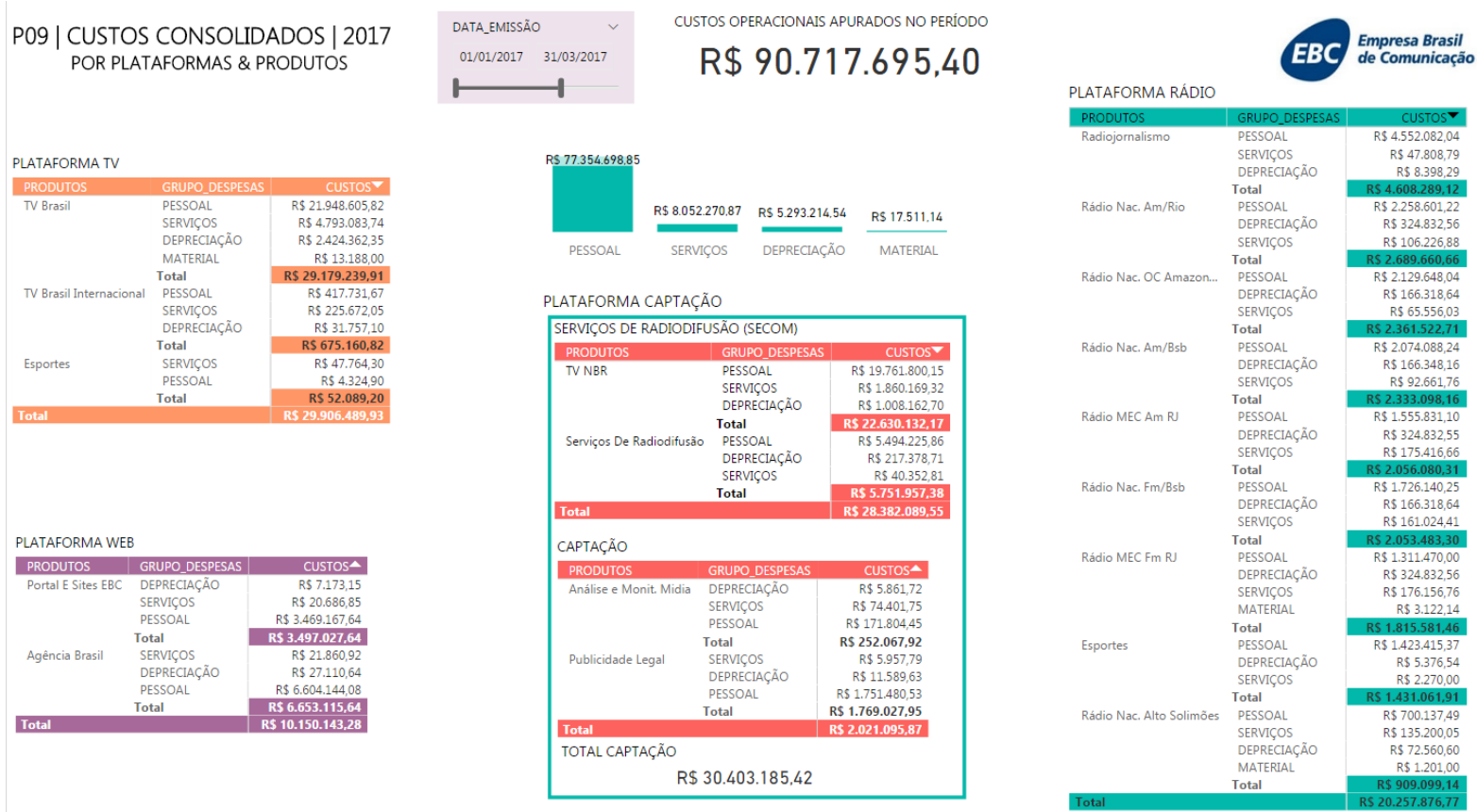

Fonte: SIAFI | Base: 18MA117 - Atualizado em 19MA17 | Coordenação de Custos | GEORC | GEXF| | DIAFI - EBC | Ramal 5610

Fonte: Souza et al. (2017, p.27)

Gráfico 8: Painel de Custos por Diretorias

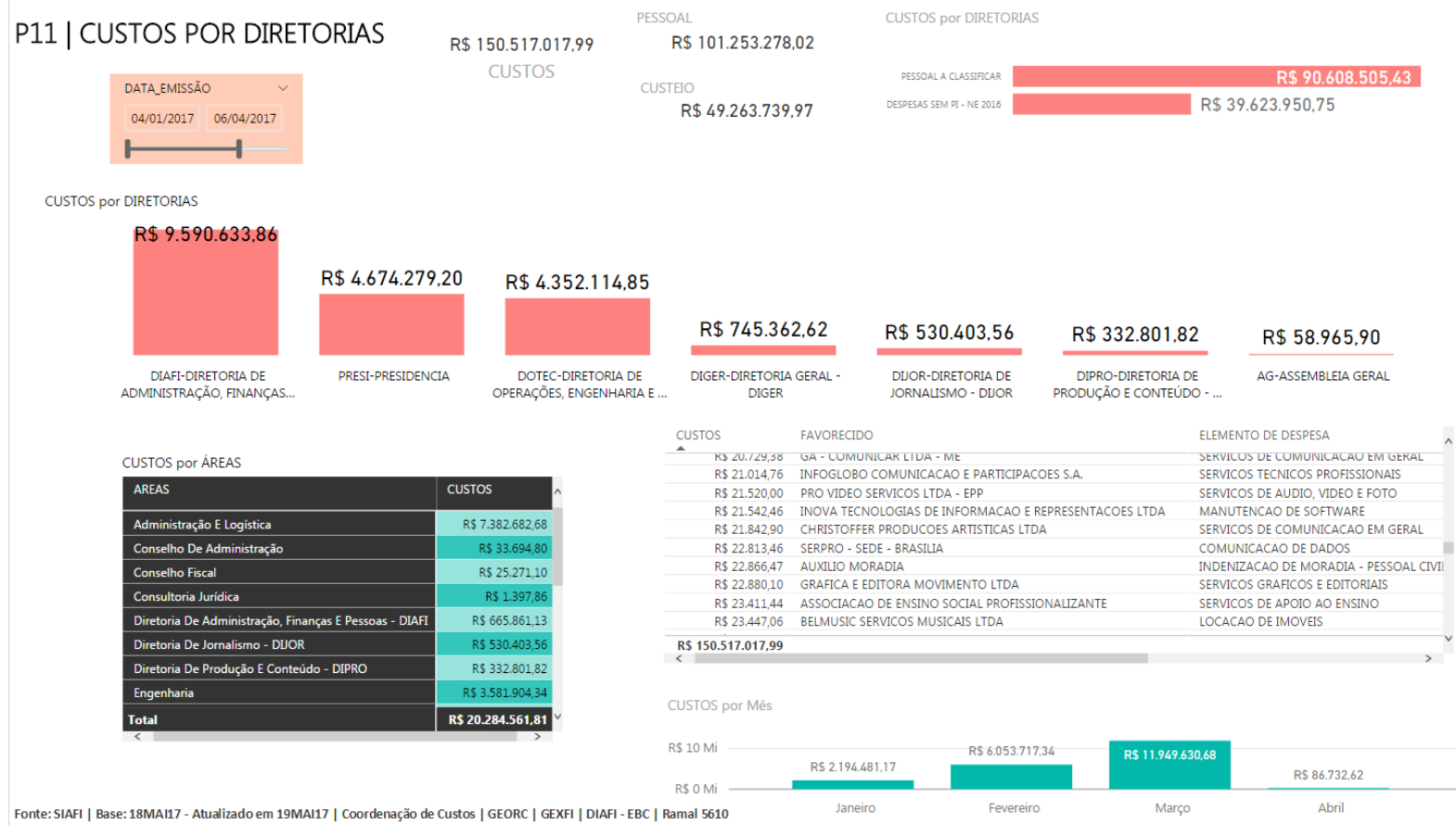

Fonte: Souza et al. (2017, p.27) 
Para demonstrar a versatilidade e dinamicidade das informações obtidas através dos painéis de controle da EBC, o Gráfico 8 retrata o controle dos custos por diretoria e por áreas, bem como um quadro analítico que mostra os detalhes da informação ora selecionada. As informações dispostas são dinâmicas, utilizando um processo de retroalimentação diária. Dessa maneira, o gestor pode monitorar a informação dos custos de sua área de responsabilidade e acompanhar as transações efetuadas, podendo tomar decisões a qualquer momento baseado na análise realizada.

Para conferir a veracidade das informações de custos obtidas, a EBC estabeleceu dois pontos de conferência, semelhante ao trabalho de auditoria nas contas de custos, com foco na qualidade na inserção dos dados. A primeira verificação compara o número atribuído ao objeto de gastos do $\mathrm{PI}$ com o do Centro de Custos, pois ambos necessariamente precisam ser iguais. Se houver diferenças são analisadas e corrigidas. A segunda verificação confronta os elementos da natureza da despesa e os objetos de gastos, considerando que o objeto de gastos é um desmembramento da natureza da despesa, portanto, devem estar devidamente relacionados.

Se forem encontradas divergências quanto ao detalhamento da natureza de despesa e o objeto de gasto correspondente são realizados os devidos ajustes. A equipe de Custos da EBC analisa diariamente os pontos de conferência visando manter a qualidade das informações de custos expostas nos painéis de controle.

Em seu relato a EBC aponta que o modelo por ela adotado pode ser aplicado a outros órgãos e entidades do setor público, investindo tempo em planejamento e utilizando as ferramentas gratuitas dos sistemas estruturantes do Governo Federal, e as ferramentas de business intelligence - BI disponíveis no mercado, inclusive o Tesouro Gerencial que possibilita a geração de dashboards.

As justificativas para apresentar essa experiência como um dos norteadores para a implementação do sistema de custos na UFRA foram os excelentes resultados obtidos, como:

- Redução de três semanas para 30 minutos diários para apuração dos custos;

- Eliminação de relatórios impressos;

- Ganhos relevantes em transparência, confiabilidade e fidedignidade das informações de custos; 
- Maior nível de detalhamento das informações de custos decorrentes dos critérios de rateio mais refinados;

- Eliminação da coleta manual de dados em processos físicos, substituído pelo modelo informatizado, além dos pontos de conferências, visando à fidedignidade das informações; e

- Interesse de diversas áreas da EBC, onde 75 empregados foram capacitados no primeiro semestre de 2017 para operar a ferramenta e criar os painéis de controle, de forma a disseminar a cultura de custos e accountability.

Destaques do relato da Experiência da EBC

A proposta de integrar custos a planejamento orçamentário, utilizando os sistemas estruturantes e ferramentas já disponíveis e gratuitas.

> Foi constituída uma Coordenação de Custos com equipe técnica exclusiva para essa finalidade.

> Foram alinhadas as informações de custos junto às áreas de gestão de pessoas, contabilidade, auditoria, almoxarifado, planejamento orçamentário e execução orçamentária.

> Foi proporcionada à equipe capacitações na ferramenta Tesouro Gerencial e no Sistema de Informação de Custos - SIC, além da participação em seminários e encontros de custos no setor público.

> A metodologia adotada pela EBC utiliza o Plano Interno (PI) conjuntamente com o Centro de Custos, para integrar custos com o planejamento orçamentário. Assim, a EBC pôde atender à NBC T 16.11 (CONSELHO FEDERAL DE CONTABILIDADE, 2012) no que tange a evidenciar o resultado econômico das ações do setor público.

$>\mathrm{A} E B C$ adotou uma metodologia de rateio dos custos indiretos a partir da identificação dos custos intermediários, para direcioná-los aos objetos de custos definidos. No rateio dos valores de aluguel, por exemplo, utilizou-se a metragem das áreas envolvidas em cada produto/serviço para alocar os valores aos produtos.

> Para gerar os painéis de controle (dashboards), a EBC extrai os dados no SIC e os trabalha através de planilhas eletrônicas para que sejam realizados os rateios e vinculação à ferramenta MS-Power BI. 
> Os painéis de controle de custos da EBC podem prestar informações detalhadas por produtos, por favorecido, por objeto de gasto, por elemento de despesas, por praças ou por notas de empenho, de forma individual ou combinada.

\subsection{Lições extraídas a partir dos relatos e etapas iniciais da estruturação}

Mediante os relatos apresentados e a necessidade de implementação de uma estrutura de gestão de custos na UFRA, considerando todas as vantagens gerenciais e de accountability, é de fundamental importância extrair o que há de mais relevante em cada experiência.

No tocante ao método de custeio por absorção, como o utilizado na EBC, entende-se como o mais adequado a ser adotado na UFRA, considerando as ferramentas disponibilizadas aos órgãos da esfera federal $e$, as orientações $e$ demonstrações da STN que levam a esse entendimento.

Ao analisar o caminho percorrido pelos órgãos que serviram de base para este estudo, foi possível identificar que são grandes os desafios a serem enfrentados até alcançar o patamar de plena estruturação e consolidação da gestão de custos. Será determinante o apoio da alta gestão da UFRA, principalmente, no que tange à força de trabalho qualificado, estrutura física adequada, mas, principalmente, o reconhecimento da importância dessa iniciativa para o aumento dos indicadores de eficiência na gestão dos recursos públicos.

A seguir, aponta-se as etapas consideradas relevantes para o início da implementação do sistema de custos na UFRA.

\section{a) Mapeamento dos processos:}

Para que a UFRA inicie sua estruturação será indispensável realizar o mapeamento dos processos realizados em cada unidade, identificar toda a força de trabalho que está envolvida nas tarefas para que, assim, possa calcular o custo de cada tarefa e o seu retorno à instituição e aos interessados. Reconhecer e listar seus macroprocessos finalísticos também é importante para o direcionamento de custos. 


\section{b) Apuração de custos da força de trabalho:}

Uma das possibilidades para apuração de custos é o cálculo do percentual de esforço dos servidores na execução das atividades, através do apontamento de horas trabalhadas. Assim, podem ser direcionados às atividades ou aos objetos de custos os valores de remuneração, depreciação, materiais de consumo, uso do espaço físico, e demais custos de fácil direcionamento.

\section{c) Benchmark:}

A comparabilidade realizada através do benchmark poderá ser um instrumento necessário à UFRA para estabelecimento de parâmetros de gastos de custeio, por exemplo, ou até mesmo os custos de pessoal de outras Universidades, desde que sejam passíveis de comparação pelas semelhanças de estrutura. De acordo com a NBCT 16.11 (CONSELHO FEDERAL DE CONTABILIDADE, 2012), item 3 , isso estimularia a melhoria do desempenho desses órgãos.

A comparação dos custos das atividades entre entidades comparáveis, através do benchmark, permite que se identifiquem as causas das diferenças de custos e adotar medidas para a revisão e melhoria dos processos de negócios.

A STN demonstrou que o SIC já está pronto para auxiliar nesse processo de comparabilidade entre unidades afins, onde é medida a Força de Trabalho e os Custos atribuíveis a Pessoal, conforme Quadro 23.

Quadro 23: Força de Trabalho x Custo atribuível a Pessoal

\begin{tabular}{|c|c|c|c|c|c|c|c|c|c|c|}
\hline Entidade & \multicolumn{2}{|c|}{ ANAC } & \multicolumn{2}{|c|}{ ANEEL } & \multicolumn{2}{|c|}{ ANATEL } & \multicolumn{2}{|c|}{ ANTT } & \multicolumn{2}{|c|}{ ANVISA } \\
\hline Ano & \multicolumn{2}{|c|}{2017} & \multicolumn{2}{|c|}{2017} & \multicolumn{2}{|c|}{2017} & \multicolumn{2}{|c|}{2017} & \multicolumn{2}{|c|}{2017} \\
\hline Semestre & $1^{0} \mathrm{SEM}$ & $2^{\circ}$ SEM & $1^{0} \mathrm{SEM}$ & $2^{\circ}$ SEM & ${ }^{10}$ SEM & $2^{\circ}$ SEM & $1^{1} \mathrm{SEEM}$ & $2^{\circ}$ SEM & $1^{\circ}$ SEM & $2^{\circ}$ SEM \\
\hline FT_Média & 1.597 & 1.671 & 557 & 553 & 1.652 & 1.646 & 586 & 599 & 440 & 424 \\
\hline $\operatorname{CAP}(\mathrm{RS})$ & 197.932.018 & 214.052 .552 & 85.966 .413 & 93.171 .350 & 206.145 .369 & 211.025 .130 & 106.406 .331 & 116.231 .408 & 108.497.411 & 103.669.774 \\
\hline \multicolumn{3}{|c|}{ CAP Esperado (R\$) } & 69.034 .523 & 70.838 .457 & 204.748 .712 & 210.850 .090 & 72.628 .781 & 76.730 .986 & 54.533 .555 & 54.313 .753 \\
\hline \multicolumn{3}{|c|}{ CAP Desvio (RS) } & 16.931 .890 & - 22.332 .894 & 1.396 .657 & 175.040 & 33.777 .550 & 39.500 .422 & 53.963 .856 & 49.356 .021 \\
\hline \multicolumn{3}{|c|}{ CAP Desvio (\%) } & $.25 \%$ & $.32 \%$ & $.1 \%$ & $0 \%$ & $47 \%$ & $51 \%$ & $.99 \%$ & $81 \%$ \\
\hline
\end{tabular}

Fonte: BRASIL. Secretaria do Tesouro Nacional. Subsecretaria de Contabilidade Pública (2018b, p.14). 
O exemplo apresentado pela STN traz os dados de algumas das Agências Reguladoras do Brasil, comparando semestralmente o custo médio por servidor, a média da força de trabalho e a disposição dos custos atribuíveis a pessoal. Para que a UFRA possa extrair essas informações pelo SIC, uma das iniciativas é levantar as tarefas desempenhadas pelo órgão para que possa absorver todos os custos da execução. Além disso, é necessária a correta alimentação dos dados de lotação e remuneração dos servidores no SIAPE e o organograma administrativo no SIORG.

\section{d) Quanto aos Centros de Custos:}

A STN, através dos Comunicas SIAFI n²018/0566550 e 2018/0659819, repassou as orientações relativas ao preenchimento das informações dos Centros de Custos no SIAFI no momento da liquidação da despesa, passando a serem obrigatórias para todas as Unidades Gestoras vinculadas ao Orçamento Fiscal e da Seguridade Social o seu devido preenchimento desde o dia 16 de abril de 2018.

Para alimentar a base de dados de custos no momento da liquidação da despesa, as Unidades Gestoras, assim como a UFRA, deverão atentar para o correto preenchimento de uma aba no SIAFI denominada "Centro de Custos". Nela o usuário poderá indicar qual o efeito do lançamento que está sendo realizado sobre aquele centro de custos, se somando ou diminuindo. Além disso, serão acrescentadas informações relativas à unidade organizacional que está consumindo aquela despesa (código SIORG), a Natureza da Despesa Detalhada, mês e ano de referência (período de competência).

A UFRA poderá elencar seus centros de custos levando em consideração as finalidades principais de uma universidade que são as atividades de ensino, pesquisa e extensão. O levantamento de informações realizado a partir da indicação dos centros de custos deve ser realizado de forma que se identifiquem onde os custos estão sendo mais consumidos e se realmente são justificáveis pelo retorno positivo que devem dar para o cumprimento da missão institucional da UFRA.

Por se tratar de uma universidade federal, recomenda-se que os centros de custos sejam definidos por estrutura administrativa (Reitoria, Pró-Reitorias, Superintendências), por unidades (Reitoria, Campus, Fazenda), por formação (Graduação, Pós-Graduação), pela forma de oferta dos cursos (Presenciais, Distância), por departamentos e cursos (Ciências Exatas, Ciências Sociais, Medicina 
Veterinária) por atividades (Ensino, Pesquisa, Extensão, Hospital Veterinário, Biblioteca, Editora, Gráfica, Laboratório, Restaurante), conforme os interesses e necessidades dos gestores.

\title{
4.4 Roteiro sugerido para uma estrutura de gestão de custos na UFRA
}

Considerando que o SIC encontra-se disponível para utilização, a UFRA não terá problemas quanto à disponibilidade de ferramentas tecnológicas. O sucesso na implantação da estrutura de custos e da utilização do sistema dependerá, principalmente, do pessoal qualificado que o alimenta e o faz funcionar. Nas palavras de Martins (2003, p. 256):

\begin{abstract}
Normalmente, o problema mais grave reside na qualificação e competência do pessoal envolvido nas fases iniciais do processamento; os primeiros informes nascem de diversos apontamentos na produção, em que o nível médio de escolaridade e o grau de interesse por serviços burocráticos são relativamente baixos. Esse nível de educação insuficiente do pessoal que inicia o processo é, em muitos casos, o grande responsável pelos insucessos de Sistemas de Custos.[...] O treinamento é obrigatório no sentido de se conseguir gradualmente a melhoria da qualidade das informações levantadas. [...] O pessoal técnico de produção é normalmente avesso à burocracia e, em geral, encara um Sistema de Custos como uma forma de controle e, devido a essas duas razões tenderá, em inúmeras situações, a rejeitar, boicotar ou simplesmente fazer resistência passiva a sua implantação. Problemas maiores ainda advirão se as informações iniciais já forem sofisticadas, ou se for relativamente difícil que tenham sua utilidade visualizada; quem não vê utilidade num dado não Ihe dá importância. Primeiro, cada elemento deve ser conscientizado da necessidade e utilidade de cada informação, para depois ser treinado a localizá-la e transmiti-la.
\end{abstract}

As informações que comporão a base de dados do SIC, e a extração desses dados para consultas e tomada de decisão, devem estar balizadas através de um estudo e desenvolvimento prévio, assim como investir na capacitação dos usuários dos sistemas, a exemplo do ocorrido na implantação realizada nos órgãos aqui estudados, O BACEN e a EBC. Baseado na experiência desses dois órgãos e também nas orientações dadas pelos órgãos superiores, traçou-se uma sugestão de roteiro para um processo pleno de implementação que pode ser utilizado na UFRA:

$\checkmark \quad$ Buscar informar e sensibilizar a gestão superior da UFRA sobre a importância do tema e da obrigatoriedade da implementação em razão das disposições legais, mas, principalmente, dos benefícios que as informações de custos 
trarão à gestão no que se refere a munir os gestores de dados que os auxiliem nas tomadas de decisão.

$\checkmark \quad$ Instituir um grupo de trabalho composto por servidores conhecedores do tema de custos e das rotinas administrativas do órgão. É imprescindível envolver também servidores da área de tecnologia da informação nesse processo, a exemplo da Fundação Universidade Federal de Mato Grosso do Sul, que através da Portaria $n^{\circ}$ 732, de 21 de Junho de 2017 (FUNDAÇÃO UNIVERSIDADE FEDERAL DO MATO GROSSO DO SUL, 2017), conforme Anexo B, autorizou a implantação do Sistema de Informação de Custos e instituiu o Grupo de Trabalho com a finalidade de modelar, aperfeiçoar e implementar o Sistema de Informação de Custos na UFMS. Para essa tarefa ficaram responsáveis: Pró-Reitoria de Planejamento, Orçamento e Finanças; Pró-Reitoria de Administração e Infraestrutura; e Agência de Tecnologia da Informação e Comunicação.

$\checkmark$ Definir a infraestrutura mínima, o tempo necessário para cada etapa da implementação e a equipe de trabalho exclusiva para que se garanta a continuidade desse projeto.

$\checkmark \quad$ Proporcionar capacitações e treinamentos aos membros do grupo de trabalho que os tornem aptos a manusear, alimentar e extrair informações dos sistemas estruturantes do Governo Federal e do Sistema de Informação de Custos.

$\checkmark \quad$ Analisar as metodologias de apuração de custos que podem ser adotadas pela UFRA, levando em consideração se há compatibilidade com o SIC, por ser um sistema gratuito disponibilizado para os órgãos da Administração Federal, mas, considerar principalmente, aquela metodologia que atende às necessidades da gestão e da Universidade. Nesta pesquisa, para a UFRA, sugere-se a utilização do método por Absorção.

$\checkmark \quad$ A depender da metodologia escolhida, se deverá realizar levantamento das atividades e dos processos que são desenvolvidos na UFRA para assim definir os objetos de custos e, se necessário, estabelecer Centros de Custos de forma personalizada. O intuito dessa etapa é definir quais as necessidades latentes da UFRA quanto à mensuração e controle de custos.

$\checkmark \quad$ Orientar as unidades administrativas que alimentam os sistemas estruturantes sobre o reflexo do preenchimento desses dados nas informações de custos. É 
importante instruí-los sobre a metodologia adotada pela UFRA para apuração de custos e a importância da fidedignidade das informações inseridas.

$\checkmark$ Estabelecimento de metas de desempenho e economicidade, com vistas a acompanhar a performance e eficiência da UFRA de um modo geral.

$\checkmark$ Definir as formas de verificação da qualidade e veracidade (auditoria) das informações inseridas nos sistemas estruturantes para sanar possíveis distorções das informações extraídas no SIC e demonstradas nos relatórios.

Esse roteiro sugere os passos considerados como fundamentais para uma plena implantação da sistemática de apuração de custos na UFRA, tendo em vista a necessidade de atender as determinações legais e fornecer ferramentas de gestão que sejam confiáveis. 


\section{CONSIDERAÇÕES FINAIS}

O cenário brasileiro atual apresenta desafios à gestão pública em razão das restrições orçamentárias impostas à Administração Federal decorrentes da crise fiscal. Consequentemente, diversas iniciativas e pesquisas surgem para buscar alternativas que proporcionem melhores resultados no tocante às finanças públicas. Nesse sentido, buscam-se instrumentos que tragam aos gestores informações úteis e oportunas que os auxiliem nas tomadas de decisão e, por sua vez, propiciem transparência na demonstração dos recursos que foram consumidos pelo seu órgão.

Dentro desse contexto, o presente trabalho buscou contribuir com o processo de implementação de uma gestão de custos na UFRA. Ressalta-se que o tema custos no setor público ainda gera muitas discussões sobre sua utilização e aplicação, principalmente sobre como estimular os órgãos e seus gestores a utilizarem a gestão de custos, posto o baixo número de órgãos brasileiros que adotam tal ferramenta, apesar da obrigatoriedade legal e das determinações normativas.

A proposta principal do presente estudo foi de demonstrar as possibilidades de utilização das Informações de Custos para apoiar as tomadas de decisões pelos gestores da Universidade Federal Rural da Amazônia - UFRA. Para isso, buscou-se na literatura brasileira duas práticas exitosas de gestão e implementação de sistema de custos, no Banco Central do Brasil e na Empresa Brasileira de Comunicação, ambas reconhecidas por especialistas e órgãos de controle, para que possam servir como balizadoras para a implementação na UFRA.

Foram relacionadas as principais legislações e normas técnicas que norteiam o processo de adoção da sistemática de apuração de custos no Brasil, assim como foram mencionados os principais benefícios dessa adoção para controle e alcance de melhores índices de eficiência nas atividades desenvolvidas pela UFRA. Ademais, os aspectos relacionados às exigências dos órgãos fiscalizadores como 0 Tribunal de Contas da União foram abordados demonstrando como isso tem contribuído para a disseminação da cultura de custos nos seus órgãos jurisdicionados.

Quanto à questão de pesquisa, as ferramentas técnicas que podem auxiliar a UFRA a implementar e utilizar a sistemática de apuração de custos, foram ilustradas mediante a experiência da Empresa Brasileira de Comunicação, onde apresenta-se 
as ferramentas do Sistema de Informações de Custos do Governo Federal (SIC) e quais as formas de alimentação, extração e apresentação das informações de custos importantes para o processo decisório por parte dos gestores da UFRA.

Ao analisar conjuntamente as duas exitosas experiências brasileiras de implementação de gestão de custos, pôde-se extrair lições e estratégias pontuais que servirão para que a utilização da Informação de Custos na UFRA realize-se de forma satisfatória, evitando que incorra em equívocos semelhantes aos relatados pelos órgãos estudados.

As análises realizadas permitiram evidenciar que os benefícios da adoção da gestão de custos compensam os dispêndios que são realizados para tanto, considerando, principalmente, o feedback que os gestores terão através dos relatórios de apuração dos custos e dos painéis de controle do SIC, dos ganhos em transparência, confiabilidade e fidedignidade das informações, e da disseminação da cultura de custos e accountability internamente no órgão.

Portanto, até que se alcance esse nível desejado de informações de custos disponíveis, o órgão deverá investir em planejamento, pessoal qualificado e recursos materiais até concluída a plena implantação. Entretanto, far-se-á o uso dos Sistemas Estruturantes do Governo Federal sem ônus adicionais, como o SIC, utilizado como ferramenta de business intelligence (BI) que possibilita a geração dos dashboards (painéis de controle).

O roteiro sugerido pode ser aplicado em outras Universidades e Institutos Federais de Ensino Superior, considerando as suas semelhanças e peculiaridades, assim como em outros órgãos e entidades públicas depois de realizadas as devidas adaptações.

Sugere-se para pesquisas futuras que se aprofundem as formas de utilização da informação de custo como um instrumento de governança nos órgãos públicos sob a percepção dos próprios gestores. Seria relevante também um estudo que avalie comparativamente o desempenho das informações de custos obtidas entre órgãos semelhantes (benchmarking) e unidades administrativas afins, apontando as melhorias que podem ser realizados mediante essa análise. 


\section{REFERÊNCIAS}

ALONSO, M. Custos no serviço público. Revista do Serviço Público, Brasília, n. 50, jan./mar. 1999. p. 37 - 63. Disponível em:

$<$ https://revista.enap.gov.br/index.php/RSP/article/view/340>. Acesso em: 10 jan. 2018.

ARAÚJO, J. F. Da nova gestão pública à nova governação pública: pressões emergentes da fragmentação da estrutura da administração pública. In: SILVESTRE, H. C.; ARAÚJO, J. F. Coletânea em Administração Pública. Lisboa: Escolar, 2013. Cap. 3.

BANCO CENTRAL DO BRASIL. Diretoria de Administração. Secretaria de Relações Institucionais. O Sistema de Custos do Banco Central do Brasil: um Estudo do Caso. Brasília: BANCO CENTRAL DO BRASIL, 2004.

BRASIL. Lei o 4.320, de 17 de março de 1964. Estatui Normas Gerais de Direito Financeiro para elaboração e controle dos orçamentos e balanços da União, dos Estados, dos Municípios e do Distrito Federal. Disponível em:<http://www.planalto. gov.br/ccivil_03/leis/L4320.htm>. Acesso em: 01 mai. 2018.

. Decreto Lei $n^{\circ} 200$ de 25 de fevereiro de 1967. Dispõe sobre a organização da Administração Federal, estabelece diretrizes para a Reforma Administrativa e dá outras providências. Disponível em:<http://www.planalto.gov.br/cciviL 03/DecretoLei/Del0200.htm>. Acesso em: 01 mar 2018.

Decreto Presidencial n 93.872 de 23 de dezembro de 1986. Dispõe sobre a unificação dos recursos de caixa do Tesouro Nacional, atualiza e consolida a legislação pertinente e dá outras providências. Disponível

em:<http://www.planalto.gov.br/ccivil 03/Decreto/D93872.htm>. Acesso em: 01 mar 2018.

. Constituição Federal de 1988. Promulgada em 5 de outubro de 1988. Disponível em:<http://www.planalto.gov.br/ccivil_03/constituicao/constituicao.htm>. Acesso em: 01 mar 2018.

. Lei Complementar no 101, de 4 de maio de 2000. Estabelece normas de finanças públicas voltadas para a responsabilidade na gestão fiscal e dá outras providencias. Disponível em:<www.planalto.gov.br/ ccivil_03/leis/LCP/Lcp101.htm>. Acesso em: 02 mai. 2018.

. Lei no 10.611, de 23 de dezembro de 2002. Dispõe sobre a transformação da Faculdade de Ciências Agrárias do Pará em Universidade Federal Rural da Amazônia e dá outras providências. Disponível em:< http://www.planalto.gov.br/ccivil_03/LEIS/2002/L10611.htm>. Acesso em: 20 dez. 2017.

Decreto oㅡ 6.096, de 24 de abril de 2007. Institui o Programa de Apoio a Planos de Reestruturação e Expansão das Universidades Federais - REUNI. 
Disponível em:<http://www.planalto.gov.br/ccivil 03/ ato20072010/2007/decreto/d6096.htm>. Acesso em: 20 dez. 2017.

. Ministério do Planejamento, Desenvolvimento e Gestão. O que é Lei

Orçamentária anual (LOA). [Brasília]: MPOG, 2015a. Disponível em:<http://www.planejamento.gov.br/servicos/faq/orcamento-da-uniao/leis-eprincipios-orcamentarios/o-que-e-lei-orcamentaria-anual-loa >. Acesso em: $21 \mathrm{dez}$. 2017.

. Ministério do Planejamento, Desenvolvimento e Gestão. O que é Lei de

Diretrizes Orçamentárias. [Brasília]: MPOG, 2015b. Disponível em:<http://www.planejamento.gov.br/servicos/faq/orcamento-da-uniao/leis-eprincipios-orcamentarios/o-que-e-lei-de-diretrizes-orcamentarias-ldo >. Acesso em: 21 dez. 2017.

. Secretaria do Tesouro Nacional. Portaria no 157, de 9 de março de 2011 a. Dispõe sobre a criação do Sistema de Custos do Governo Federal. Disponível em:<http://www.fazenda.gov.br/pmimf/frentes-de-atuacao/custos/download-dearquivos/portstn_157_09mar2011.pdf>. Acesso em: 20 dez. 2017.

. Secretaria do Tesouro Nacional. Portaria ํㅜ 716, de 24 de outubro de 2011b. Dispõe sobre Sistema de Custos do Governo Federal. Disponível em:<https://www.legisweb.com.br/legislacao/?id=234413>. Acesso em: $20 \mathrm{dez}$. 2017.

. Secretaria do Tesouro Nacional. Portaria ํo 864, de 30 de dezembro de 2011c. Altera a Portaria STN o 607, de 26 de outubro de 2010 e cria o Macroprocesso do Sistema de Custos do Governo Federal - MPCUST. Disponível em:<http://www.tesouro.fazenda.gov.br/documents/10180/113505/Portaria_864_MP CUST_GSISTE.pdf>. Acesso em: 20 dez. 2017.

Secretaria do Tesouro Nacional. Sistema de Informação de Custos: evoluções. In: ENCONTRO DE GESTÃO DE CUSTOS DO SETOR PÚBLICO, 5., Brasília, 2017a. Disponível em:<http://www.tesouro.fazenda.gov.br/-/v-encontro-degestao-de-custos-do-setor-publico>. Acesso em: 20 dez. 2017.

\section{. Secretaria do Tesouro Nacional. Guia Rápido do SIC - Sistema de}

Informações de Custos do Governo Federal. [Brasília]: Secretaria do Tesouro Nacional, 2017b. Disponível em:

<https://conteudo.tesouro.gov.br/manuais/modules/mod_pdf_manual/pdf/grsic.pdf> Acesso em: 31 ago 2017.

Secretaria do Tesouro Nacional. Manual do Portal de Custos do Governo Federal. Brasília: Ministério da Fazenda; Secretaria do Tesouro Nacional, 2017c. Disponível em: <http://www.tesouro.fazenda.gov.br/documents/10180/626285/Manual+do+Portal+de +Custos+do+Governo+Federal/1c605b35-45a8-451d-8d13-39f57366b36d>. Acesso em: 20 dez. 2017. 
Secretaria do Tesouro Nacional. Entendendo e utilizando o Sistema de Informação de Custos (SIC). [Brasília]: [STN], 2017d. Material de apoio do Curso Entendendo e utilizando o Sistema de Informação de Custos (SIC) ministrado em agosto de 2017, na Escola de Administração Fazendária.

. Secretaria do Tesouro Nacional. Subsecretaria de Contabilidade

Pública. Custos no Setor Público: atitudes, inovações e perspectivas In: SEMINÁRIO BRASILEIRO DE CONTABILIDADE E CUSTOS APLICADOS AO SETOR PÚBLICO, 5., 2018a, Brasília: Conselho Federal de Contabilidade, 2018. Disponível em:<https://cfc.org.br/wp-content/uploads/2018/01/CUSTOS-NO-SETORP\%C3\%9ABLICO-ATITUDES-INOVA\%C3\%87\%C3\%95ES-E-PERSPECTIVA-.pdf>. Acesso em: 20 maio 2018.

Secretaria do Tesouro Nacional. Sistema de Informações de Custos. [Brasília]: [STN], 2018b. Disponível em:<http://tesouro.fazenda.gov.br/pt_PT/sistema-de-informacoes-de-custos>. Acesso em: 25 fev. 2018.

. Sistema de Informações organizacionais. [Organograma da Universidade Federal Rural da Amazônia]. [Brasília]: [SIORG], 2018. Disponível em:<https://siorg.planejamento.gov.br/siorg-cidadaowebapp/pages/organograma/organograma.jsf?id=42337. Acesso em: 08 jan. 2018.

2004. Disponível

Tribunal de Contas da União. Acórdão n 1078 (Segunda Câmara). em:<http://www.tcu.gov.br/Consultas/Juris/Docs/judoc\%5CRELAC\%5C20051206\%5 CGERADO TC-43154.pdf>. Acesso em: 20 dez. 2017.

. Tribunal de Contas da União. Resolução TCU $n^{\circ} 234$, de $1^{\circ}$ de setembro de 2010a. Estabelece diretrizes a serem observadas pelas unidades internas do Tribunal na elaboração das normas previstas em Instrução Normativa do TCU e no tratamento das peças e conteúdos relacionados à prestação de contas das unidades jurisdicionadas. Disponível

em:<www.tcu.gov.br/Consultas/Juris/Docs/judoc/Resol/20100903/RES2010-234.rtf>. Acesso em: 20 dez. 2017.

Tribunal de Contas da União. Instrução Normativa nำ63, de 1ำ de setembro de 2010b. Estabelece normas de organização e de apresentação dos relatórios de gestão e das peças complementares que constituirão os processos de contas da administração pública federal, para julgamento do Tribunal de Contas da União, nos termos do art. $7^{\circ}$ da Lei no 8.443 , de 1992.

Disponível em:< www.tcu.gov.br/Consultas/Juris/Docs/judoc/IN/20100903/INT2010063.rtf>. Acesso em: 20 dez. 2017.

. Tribunal de Contas da União. Resolução nํ244, de 20 de julho de 2011. Altera dispositivos da Resolução TCU nํ2 234, de 1ํำ de setembro de 2010, que estabelece diretrizes a serem observadas pelas unidades internas do Tribunal na elaboração das normas previstas em Instrução Normativa do TCU e no tratamento das peças e conteúdos relacionados à prestação de contas das unidades jurisdicionadas. Disponível 
em:<www.tcu.gov.br/Consultas/Juris/Docs/judoc/Resol/20110721/RES2011-244.rtf>. Acesso em: 20 dez. 2017.

. Tribunal de Contas da União. Instrução Normativa no 72, de 15 de maio de 2013. Altera a Instrução Normativa-TCU oㅡ 63, de 1ํ de setembro de 2010, que estabelece normas de organização e de apresentação dos relatórios de gestão e das peças complementares que constituirão os processos de contas da administração pública federal, para julgamento do Tribunal de Contas da União, nos termos do art. 7ํㅡㄹ Lei oㅜ 8.443, de 1992.

Disponível em:< www.tcu.gov.br/Consultas/Juris/Docs/judoc/IN/20100903/INT2010063.rtf>. Acesso em: 20 dez. 2017.

Tribunal de Contas da União. Orientações para elaboração do conteúdo do item Sistemática de apuração de custos no âmbito da unidade. [Brasília]: [TCU], 2016. Disponível em:<https://proplan.ufba.br/sites/proplan.ufba.br/files/Sistem\%C3\%A1tica\%20de\%20 apura\%C3\%A7\%C3\%A30\%20de\%20custos\%20no\%20\%C3\%A2mbito\%20da\%20un idade.pdf>. Acesso em: 25 nov. 2017.

BRESSER PEREIRA, L. C. Da Administração Pública Burocrática à Gerencial. Revista do Serviço Público, Brasília, ano 47, v. 120, n.1, p.7-40, jan./abr., 1996. Disponível em: <http://repositorio.enap.gov.br/handle/1/2089>. Acesso em: 01 nov. 2017.

CONSELHO FEDERAL DE CONTABILIDADE. Normas brasileiras de contabilidade: contabilidade aplicada ao setor público: NBCs T 16.1 a 16.11. Brasília: Conselho Federal de Contabilidade, 2012. Disponível em:<http://portalcfc.org.br/wordpress/wpcontent/uploads/2013/01/Setor_P\%C3\%BAblico.pdf>. Acesso em: 01 mar. 2018.

. Norma Brasileira de Contabilidade, NBC TSP Estrutura Conceitual, de 23 de Setembro de 2016. Aprova a NBC TSP ESTRUTURA CONCEITUAL - Estrutura Conceitual para Elaboração e Divulgação de Informação Contábil de Propósito Geral pelas Entidades do Setor Público. Disponível em:<http://www2.cfc.org.br/sisweb/sre/detalhes_sre.aspx?Codigo=2016/NBCTSPEC \&arquivo=NBCTSPEC.doc $>$. Acesso em: 20 dez. 2017.

COSTA JUNIOR, F.T. Gestão De Custos No Setor Público: análise da viabilidade de implantação do sistema de informações de custo do Governo Federal (SIC) no Instituto Federal de Educação, Ciência e Tecnologia da Paraíba (IFPB). 2016. 115 f. Dissertação (Mestrado Profissional em Gestão Pública) - Universidade Federal do Rio Grande do Norte. Natal, 2016.

\section{ELIAS, L.M.S. de L. Sistema de informação de custos no Setor Público}

Municipal: um estudo sistêmico no Estado do Pará. 2018158 f. Tese (Doutorado em Desenvolvimento Sustentável do Trópico Úmido) - Núcleo de Altos Estudos Amazônicos, Universidade Federal do Pará, Belém, 2018.

FARIA, C. E. P. Procedimentos Peculiares da Contabilidade Governamental e sua Influência na Gestão de Custos do Setor Público. In: CONGRESSO UFSC DE 
CONTROLADORIA E FINANÇAS, 3., 2009, Florianópolis. Anais... Florianópolis: [UFSC], 2009. Disponível em:

<http://dvl.ccn.ufsc.brcongressoanais3CCF20090810113949.pdf> Acesso em: 14 dez. 2017.

FARIAS FILHO, M. C. F.; CORDEIRO, E. J. M. A. Planejamento da Pesquisa Científica. São Paulo: Atlas, 2013.

FUNDAÇÃO UNIVERSIDADE FEDERAL DE MATO GROSSO DO SUL. Portaria no 732, de 21 de junho de 2017. Autoriza a implantação do Sistema de Informação de Custos no âmbito da Fundação Universidade Federal de Mato Grosso do Sul, sob a responsabilidade da Pró-reitoria de Planejamento e Finanças. Disponível em:<https://bse.ufms.br>. Acesso em: 17 jan. 2018.

G1. Veja o impacto do corte de verbas em universidades e institutos federais de 14 estados. [Portal de notícias G1], [São Paulo], 28 nov. 2017. Disponível em:<https://g1.globo.com/educacao/noticia/veja-o-impacto-do-corte-de-verbas-emuniversidades-e-institutos-federais-de-14-estados.ghtml>. Acesso em: 20 dez. 2017.

GIL, A. C. Métodos e Técnicas de Pesquisa Social. 5. ed. São Paulo: Atlas, 1999.

GNISCI, E. F. S. A Implementação do Sistema de Informação de Custos do

Setor Público: o Caso do Governo Federal. 2010. 81 f. Dissertação (Mestrado em Gestão Pública) - Escola Brasileira de Administração Pública e de Empresas, Fundação Getúlio Vargas, Rio de Janeiro, 2010.

HOLANDA, V. B; LATTMAN-WELTMAN, F.; GUIMARÃES, F. (Orgs.). Sistema de Informação de Custos na Administração Pública Federal: uma política de Estado. Rio de Janeiro: FGV, 2010.

KAUARK, F. S.; MANHÃES, F.C.; MEDEIROS, C.H. Metodologia da Pesquisa: um guia prático. Itabuna: Via Litterarum, 2010.

MACHADO, N. Sistema de informação de custo: diretrizes para integração ao orçamento público e à contabilidade governamental. 2002. 232 f. Tese (Doutorado em Controladoria e Contabilidade) - Faculdade de Economia, Administração e Contabilidade, Universidade de São Paulo, São Paulo, 2002.

MACHADO, N.; HOLANDA, V. B. de. Diretrizes e modelo conceitual de custos para o setor público a partir da experiência no Governo Federal do Brasil. Revista de Administração Pública, Rio de Janeiro, v. 44, n. 4, p. 791-820, jul./ago. 2010.

MARTINS, E. Contabilidade de Custos. 9. ed. São Paulo: Atlas, 2003.

MORGAN, B. F.; ROSA, M. S. Custos em Empresas Prestadoras de Serviços: o conceito de objeto de custo e a realidade das empresas. Contab. Vista \& Rev., Belo Horizonte, v. 17, n. 4, p. 97-111, out./ dez. 2006.

MONTEIRO, B. R. P. et al. O processo de implantação do sistema de informação de custos do Governo Federal do Brasil. In: CONGRESSO INFORMAÇÃO DE CUSTO 
E QUALIDADE DO GASTO NO SETOR PÚBLICO, 1., 2010, Brasília. Anais... Brasília: [Ministério da Fazenda], 2010.

. O processo de implantação do sistema de informação de custos do

Governo Federal do Brasil. 2011. Disponível em:

<http://www3.tesouro.gov.br/Sistema_Informacao_custos/downloads/PROCESSO_D E_IMPLANTAÇÃO_DO_SIC.pdf>. Acesso em: 23 nov. 2017.

MONTOTO, E. Contabilidade Geral e Avançada Esquematizado. 4. ed. São Paulo: Saraiva, 2015 (Coordenação de Pedro Lenza).

NEGREIROS L.F.et al. Relação entre custos e desempenho dos alunos do ensino fundamental: um estudo de caso em Ibiporã/PR. In: CONGRESSO BRASILEIRO DE CUSTOS, 20., 2013, Uberlândia. Anais... [São Leopoldo]: [Associação Brasileira de Custos], 2013.

NEVES, S; VICECONTI, P.E.V. Contabilidade de Custos: um enfoque direto e objetivo. 7 ed. rev. e ampl. São Paulo. Frase Editora, 2003.

OLIVEIRA, A.B.R. Política de Custos como Instrumento de Gestão: um Estudo no Centro de Pesquisas Gonçalo Moniz - Fiocruz. 2012. 149 f. Dissertação (Mestrado Profissional em Administração) - Universidade Federal da Bahia, Salvador, 2012.

PACELLI, G. Contabilidade Pública. [Salvador]: Podimvm, 2018. (Coordenação de Sérgio Adriano)

PARCIANELO, E.; GONÇALVES, H.S.; SOARES, C.S. A contabilidade de custos no setor público: a realidade das prefeituras da região central do RS. In: CONGRESSO DE CONTABILIDADE, [1]., Florianópolis. Anais... Florianópolis: Universidade Federal de Santa Catarina, 2015. Disponível em:

$<$ http://dvl.ccn.ufsc.brcongresso_internacionalanais6CCF25_15.pdf> Acesso em: 01 nov. 2017.

PIGATTO, J. A. M. et al. A importância da contabilidade de competência para a informação de custos governamental. Revista de Administração Pública, Rio de Janeiro, v. 44, n. 4, p. 821 - 837. jul./ago., 2010. Disponível em:

<http://www.scielo.br/pdf/rap/v44n4/v44n4a04.pdf>. Acesso em: 31 out. 2017.

REZENDE, F.; CUNHA, A.; BEVILACQUA, R. Informações de custos e qualidade do gasto público: lições da experiência internacional. Revista de Administração Pública, Rio de Janeiro, v. 44, n. 4, p.959-992, jul./ago. 2010.

ROMANO, Márcio. Métodos de Custeio no setor público: um estudo sobre como as informações de custos atendem aos diversos stakeholders de um hospital universitário público. 2015. 69 f. Dissertação (Mestrado em Ciências Contábeis) Universidade do Estado do Rio de Janeiro, Rio de Janeiro, 2015.

ROMÃO, D. P. Proposta de Precificação de Serviço Público. 2007. 118 f.

Dissertação (Mestrado em Engenharia de Produção) - Escola de Engenharia de São Carlos, Universidade de São Paulo, São Carlos, SP, 2007. 
Disponível em: <http://www.teses.usp.br/teses/disponiveis/18/18140/tde-10122007143514/publico/PRECIFICACAODESERVICOPUBLICO.pdf>. Acesso em: 06 mai. 2018.

SANTOLIN, W. M. A informação de custos como ferramenta para o planejamento orçamentário: a experiência no exército brasileiro. In: CONGRESSO

INTERNACIONAL DE CONTABILIDADE, CUSTOS E QUALIDADE DO GASTO NO SETOR PÚBLICO, 6., 2016, Natal. Anais... Natal: Instituto Social Iris, 2017 p. 127153. Disponível em:

$<$ http://www.socialiris.org/premiochicoribeiro/materiais/Anais_VICongressoCQ.pdf>. Acesso em: 20 dez. 2017.

SOUZA, E. A.; et al. Sistematização de Custos no Setor Público com Uso de Ferramentas de BI (Business Intelligence): Um Relato de Experiência da Implantação de Custos na Empresa Brasil de Comunicação S/A - EBC. In: CONGRESSO INTERNACIONAL DE CONTABILIDADE, CUSTOS E QUALIDADE DO GASTO NO SETOR PÚBLICO, 7., 2017, Natal. Anais... Natal, Instituto Social Iris, 2018. p. 53-81.

UNIVERSIDADE FEDERAL RURAL DA AMAZÕNIA. Planejamento Estratégico Institucional da UFRA: 2014 - 2024. Belém: UFRA, 2014. Disponível em:<https://novo.ufra.edu.br/images/PROPLADI_PLAIN_UFRA_20142024_CONSUN.pdf>. Acesso em: 24 nov. 2017.

UNIVERSIDADE FEDERAL RURAL DA AMAZÔNIA. Prestação de contas Ordinária Anual: Relatório de Gestão do exercício de 2016. Belém: UFRA, 2017a. Disponível em: <https://novo.ufra.edu.br/images/Relatrio-de-Gesto-Final-UFRA-AnoBase-2016-2.pdf> Acesso em: 02 abr. 2018.

UNIVERSIDADE FEDERAL RURAL DA AMAZÔNIA. Relatório de Gestão do exercício de 2017. Belém: UFRA, 2017b. Disponível em: <audin.ufra.edu.br/.../relatorios_de_gestao/Relatrio-de-Gestao---2018-2017---PubTCU.pdf> Acesso em: 02 maio 2018. 
ANEXO A

DATA: $26 / 03 / 18$

HORA: $11: 26: 38$

USUARIO: MAURICIO

PAGINA: 1

MENSAGEM: 2018/0508904 DA EMISSORA 170995 COORDENACAO INEORM FISCAL E DE CUSTOS EM 26/03/18 AS 10:48: POR CELSO THOMAS COSTA FERREIRA

ASSUNTO: ABA CENTRO CUSTOS - UTILIZAÇÃO OBRIGATÓRIA POR TODAS AS UG S OFSS

PREZADOS GESTORES, BOM DIA (BOA TARDE)!

VISANDO A MELHORIA NA QUALIDADE DA INFORMAÇÃO DE CUSTOS, A STN ESTÁ EM FASE FINAL DE IMPLEMENTAÇ̃O DO PROJETO PARA QUE TODAS AS UNIDADES GESTORAS PERTENCENTES AO ORÇAMENTO EISCAL E DA SEGURIDADE SOCIAL PASSEM A A INSERIR DADOS NA ABA CENTRO DE CUSTO DO DOCUMENTO HÁBIL (DH).

O PREENCHIMENTO DESSA ABA SERÁ SOLICTTADO QUANDO O GESTOR INSERIR NO DH SITUAÇÕES CUJO PARÂMETRO "EFEITO SOBRE CENTRO DE CUSTO" ESTEJA ASSINALADO COM "SOMA" OU "SUBTRAI"; ESSE PARÂMETRO JÁ PODE SER CONSULTADO, HOJE, POR MEIO DA TRANSAÇAOO CONSIT, DISPONIVEL NO SIAFIWEB.

TAMBÉM DECORRENTE DESSE PROJETO, ALERTAMOS SOBRE A CRIAÇA DE DOIS NOVOS CAMPOS NA ABA CENTRO DE CUSTO: "NATUREZA DA DESPESA DETALHADA" E "CÓDIGO SIORG".

POR OPORTUNO, INFORMAMOS OUE OS GESTORES RESPONSÁVEIS PELOS PRINCIPAIS SISTEMAS QUE ENVIAM ARQUIVOS VIA WEBSERVICE E SUBMISSÄO BATCH FORAM COMUNICADOS SOBRE A ALTERAÇÃO QUE DEVERÃO PROMOVER NO LEIAUTE DE SEUS ARQUIVOS - DOCUMENTAÇĀO: HTTP://TESOURO.GOV. BR/WEB/STN/WEBSERVICES.

A SEGUIR, DESCREVEM-SE A OPERACIONALIZAÇÃO E A FUNÇÃO DE CADA CAMPO DA ABA PARA SEU CORRETO PREENCHIMENTO:

1) CLICAR NA CAIXA AO LADO ESQUERDO DE CADA CÓdIGO DE SITUAÇÃo OU CLICAR NA CAIXA AO LADO ESQUERDO DO CABEÇALHO (ESSA ÚLTIMA CAIXA ACIONARÁ TODAS AS CAIXAS).

2) INDICAR O "VALOR CUSTO". ESSE VALOR PODERÁ SER SEGREGADO EM "CENTRO DE CUSTO", "MÊS REFERÊNCIA", "ANO REFERÊNCIA", "Ug BENEFICIADA" E "CóDIGO SIORG" DIFERENTES, CONFORME A SEGUIR:

a) "Centro de custo" - indica o detalhamento do centro de custo.

ESSE CAMPO SOMENTE É UTILIZADO POR UNIDADES QUE POSSUEM UM MODELO PERSONALIZADO DE CUSTOS, O QUE IMPLICA MANTER O CADASTRO DE CENTROS DE CUSTO NO SIAEI OPERACIONAL. PARA AS UG/ÓRGÃOS QUE NÄO DESENVOLVERAM MODELAGEM PRÓPRIA, O SISTEMA TRARÁ AUTOMATICAMENTE UM CÓDIGO GENÉRICO.

B) "MÊS $E$ ANO REFERENCIA": INDICAM O PERÍODO DE COMPETÊNCIA DO FATO GERADOR, INDEPENDENTE DO MOMENTO DA LIQUIDAÇÄO OU PAGAMENTO, PODE SER DATA RETROATIVA, ATUAL OU FUTURA. POR EXEMPLO: PERIODO EM QUE O SERVIÇO FOI EFETIVAMENTE PRESTADO, O ESTOQUE FOI CONSUMIDO, OCORREU DEPRECIAÇÃO E AMORTIZAÇÃO DE BENS MÓVEIS E INTANGÍVEIS, ETC.

C) "CÓDIGO SIORG": PREENCHIDO AUTOMATICAMENTE COM O CÓDIGO SIORG DO DA "UG EMITENTE" DO DOCUMENTO HÁBIL, CONFORME ASSINALADO NA TABELA DE ÓRGĀO (TRANSAÇÃO ">CONORGAO"). TRATA-SE DE CÓDIGO DA UNIDADE ORGANIZACIONAL PERTENCENTE Ȧ ESTRUTURA REGIMENTAL INTERNA DO ÓRGÃO. TAL CODIFICAÇÃO É GERENCIADA PELO SISTEMA DE INEORMAÇŌES ORGANIZACIONAIS DO GOVERNO FEDERAL- SIORG, SOB GESTÃO DO MINISTÉRIO DO PLANEJAMENTO, DE- 
USUARIO: MAURICIO

PAGINA: $\quad 2$

MENSAGEM: 2018/0508904 DA EMISSORA 170995 COORDENACAO INFORM FISCAL E DE CUSTOS EM 26/03/18 AS 10:48: POR CELSO THOMAS COSTA FERREIRA

ASSUNTO: ABA CENTRO CUSTOS - UTILIZAÇÃO OBRIGATÓRIA POR TODAS AS UG'S OFSS

SENVOLVIMENTO E GESTÃO.

D) "UG BENEFICIADA": PREENCHIDO AUTOMATICAMENTE COM OS DADOS DA "UG EMITENTE DO DOCUMENTO HÁBIL, DEVENDO SER ALTERADO PELO QSUÁRIO, CASO A UG BENEEICIADA, AQUELA QUE EFETIVAMENTE USUFRUIU O BENEFÍCIO DO CONSUMO DO RECURSO, SEJA OUTRA.

E) "NATUREZA DA DESPESA DETALHADA": CODIFICAÇÃO QUE PODERÁ SER CONSULTADA POR MEIO DA TRANSAÇÃO ">CONNATSOE". NO CASO DE SITUAÇÕES APLICADAS NAS ABAS "PRINCIPAL COM ORÇAMENTO", "ENCARGOS" E "DESPESAS A ANULAR", O SISTEMA TRARÁ O CÓDIGO ND DETALHADA AUTOMATICAMENTE PREENCHIDO; NO CASO DE SITUAÇÕES APLICADAS NAS ABAS "PRINCIPAL SEM ORÇAMENTO" E "OUTROS LANÇAMENTOS", ALGUMAS TAMBÉM TERÃO O PREENCHIMENTO AUTOMÁTICO, OUTRAS TERÃO O PREENCHIMENTO MANUAL, PELO GESTOR, E OUTRAS NÃO NECESSITARÃO DA "NATUREZA DE DESPESA DETALHADA".

CUMPRE SALIENTAR QUE O CORRETO PREENCHIMENTO DESSES CAMPOS DA FORMA ADEQUADA É DE SUMA IMPORTÂNCIA PARA GERAÇÃO DE INFORMAÇÃO DE CUSTOS.

OS QUESTIONAMENTOS DEVERÃO SER DIRIGIDOS À COORDENAÇÃO DE INFORMAÇÃO CUSTOS DA SECRETARIA DO TESOURO NACIONAL, PREFERENCIALMENTE PELA UNIDADE SETORIAL DE CUSTOS DE ÓRGÃO SUPERIOR, UTILIZANDO OS CANAIS:

A) COMUNICA SIAFI: UG 170995

B) PELA CAIXA DE EMAIL INSTITUCIONAL: CUSTOSOTESOURO.GOV.BR

RESSALTAMOS QUE O TEMA OBJETO DESTA MENSAGEM FOI APRESENTADO NO VI ENCONTRO DE GESTÃO DE CUSTOS, OCORRIDO EM 21 DE NOVEMBRO DE 2017 (VÍDEO 1), E III ENCONTRO DAS SETORIAIS DE CONTABILIDADE, EM 22 DE NOVEMBRO DE 2017 (VÍDEO 2). O SLIDE DA APRESENTAÇÃO DO VI ENCONTRO ESTÁ DISPONÍVEL NO ENDEREÇO ELETRÔNICO DA STN: WWW.TESOURO. FAZENDA.GOV.BR > >RESPONSABILIDADE FISCAL $\gg$ CONTABILIDADE PÚBLICA $\gg$ TREINAMENTOS E EVENTOS $\gg$ TREINAMENTOS E EVENTOS DE CUSTOS $\gg$ VI ENCONTRO DE CUSTOS DE GESTÄO DE CUSTOS DO SETOR PÚBLICO > PAINEL 3.

VÍDEO 1: A PARTIR DE 2 HORAS E 55 MINUTOS DA GRAVAÇÃO HTTP: //ASSISTE. SERPRO.GOV. BR/ESAF/VIDEO. PHP? NOME $=224914$ VÍDEO 2: A PARTIR DE 5 HORAS E 24 MINUTOS DA GRAVAÇÃO HTTP: //ASSISTE. SERPRO.GOV.BR/ESAF/VIDEO. PHP?NOME $=224918$ ----DIGITAR ESSES ENDEREÇOS NO BROWSER COM LETRAS EM MINÚSCULO-----AS ALTERAÇÕES ESTÃO PREVISTAS PARA ENTRAREM EM PRODUÇÃO/FUNCIONAMENTO ATÉ 30 DE ABRIL DE 2018 E SERÁ ENCAMINHADO COMUNICADO SIAFI INFORMANDO SOBRE A DATA ESPECIFICA.

ATENCIOSAMENTE, COINC/SUCON/STN 


\section{ANEXO B}

O REITOR DA FUNDAÇÃO UNIVERSIDADE FEDERAL DE MATO GROSSO DO SUL, no uso de suas atribuições legais e considerando os Arts. 85 e 99 da Lei 4.320 , de 17 de março de 1964, o Art. 79 do Decreto-Lei 200, de 25 de fevereiro de 1967, o Art. 15 da Lei 10.180 , de 06 de fevereiro de 2001, o $\S 3^{\circ}$ do Art. 50 da Lei Complementar 101, de 4 de maio de 2000 e a Portaria STN 157, de 9 de março de 2011, resolve:

Art. $1^{\circ}$ Autorizar a implantação do Sistema de Informação de Custos no âmbito da Fundação Universidade Federal de Mato Grosso do Sul, sob a responsabilidade da Pró-Reitoria de Planejamento, Orçamento e Finanças.

Art. $2^{\circ}$ Instituir o Grupo de Trabalho destinado a modelar, aperfeiçoar e implementar o Sistema de Informação de Custos da UFMS, composto pelas seguintes Unidades:

a) Pró-Reitoria de Planejamento, Orçamento e Finanças;

b) Pró-Reitoria de Administração e Infraestrutura;

c) Agência de Tecnologia da Informação e Comunicação.

Parágrafo Único. O Grupo de Trabalho será coordenado pela PróReitoria de Planejamento, Orçamento e Finanças.

Art. $3^{\circ}$ Serão responsáveis para subsidiar, com informações mensais, a implantação do Sistema de Informações de Custos, conforme segue abaixo:

1. Pró-Reitoria de Planejamento, Orçamento e Finanças

1.1 Coordenadoria de Gestão Financeira e Contábil (CFC/PROPLAN) consolidação, organização e registro das informações de custos no Sistema Integrado de Administração Financeira do Governo Federal - SIAFI

2. Pró-Reitoria de Administração:

2.1 Coordenadoria de Gestão de Materiais (CGM/PROADI): informações relacionadas a saídas de materiais de consumo do almoxarifado e depreciação dos equipamentos e materiais permanentes.

2.2 Coordenadoria de Serviços (CSV/PROADI): informações relativas aos serviços prestados sob sua gestão.

2.3 Coordenadoria de Manutenção (CMT/PROADI): informações relativas aos serviços prestados sob sua gestão.

2.4 Coordenadoria de Obras, Projetos e Sustentabilidade (CPO/PROADI): informações relativas aos serviços prestados sob sua gestão

\section{GABINETE DA REITORIA}

Cidade Universitária, $s / n^{\circ}$ Fone: (067) 3345-7010/7985/7982

79070-900 Campo Grande - MS

Site: $\underline{\text { http: } / / \text { www.ufms.br }}$ * E-mail: reitoria@ufms.br 
Serviço Público Federal

Ministério da Educaçẫo

Fundação Universidade Federal de Mato Grosso do Sul

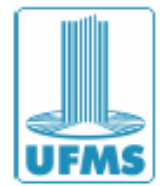

3. Pró-Reitoria de Gestão de Pessoas:

3.1 Coordenadoria de Administração de Pessoal (CAP/PROGEP): informações relacionadas a despesas com pessoal e encargos sociais.

4. Agência de Tecnologia da Informação e Comunicação (AGETIC/RTR):

4.1 Coordenadoria de Gestão de Sistemas: informações relacionadas a amortização de software e adequação de sistemas internos visando obter relatórios gerenciais destinados ao registro das informações de custo.

5. Demais Unidades da Administração Central e Unidades da Administração Setorial: informações relacionadas ao custo no âmbito de sua competência.

Art. $4^{\circ} \mathrm{O}$ prazo para conclusão da implantação será de seis meses.

Art. $5^{\circ}$ Esta Portaria entra em vigor em $1^{\circ}$ de julho de 2017.

MARCELO AUGUSTO SANTOS TURINE

GABINETE DA REITORIA

Cidade Universitánia, $s / \mathrm{n}^{\circ}$

Fone: (067) 3345-7010/7985/7982

79070-900 Campo Grande - MS

Site: $\underline{\text { http: } / / \text { www.ufms.br }} *$ E-mail reitoria@ufms.br 